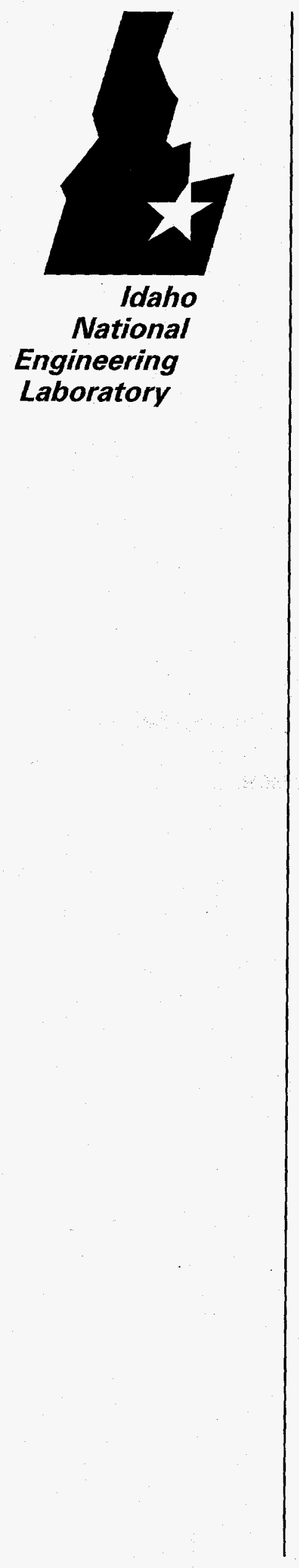

INEEL/EXT-97-01082

September 1997

\title{
Environmental Management Compliance Reengineering Project FY 1997 Report
}

J. A. VanVliet, Chairman

Compliance Reengineering Steering Board

J. N. Davis

Project Manager

L OCKHEED MARTIN 
INEEL/EXT-97-01082

\title{
Environmental Management Compliance Reengineering Project FY 1997 Report
}

\author{
J. A. VanVliet \\ Chairman, Compliance Reengineering Steering Board \\ J. N. Davis \\ Project Manager
}

Published September 1997

Idaho National Engineering and Environmental Laboratory Environmental Management

Lockheed Martin Idaho Technologies Company Idaho Falls Idaho 83415

DSTRBUTION OF THS DOCUNET IS UUTHED
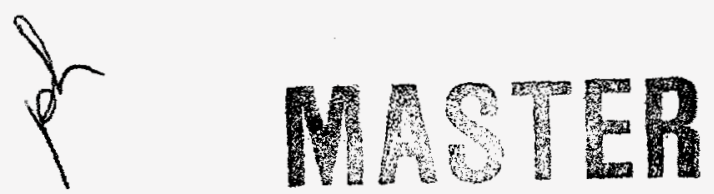

\author{
Prepared for the \\ U.S. Department of Energy \\ Assistant Secretary for \\ Environmental Management \\ Under DOE Idaho Operations Office \\ Contract DE-AC07-941D13223
}




\section{DISCLAIMER}

This report was prepared as an account of work sponsored by an agency of the United States Government. Neither the United States Government nor any agency thereof, nor any of their employees, makes any warranty, express or implied, or assumes any legal liability or responsibility for the accuracy, completeness, or usefulness of any information, apparatus, product, or process disclosed, or represents that its use would not infringe privately owned rights. Reference herein to any specific commercial product, process, or service by trade name, trademark, manufacturer, or otherwise does not necessarily constitute or imply its endorsement, recommendation, or favoring by the United States Government or any agency thereof. The views and opinions of authors expressed herein do not necessarily state or reflect those of the United States Government or any agency thereof. 


\section{DISCLAMIER}

Portions of this doecoment may be illegibie in electronic irogge produets. Images are produced frow the best available origional documenter 


\begin{abstract}
Through an integrated reengineering effort, the Idaho National Engineering and Environmental Laboratory (INEEL) is successfully implementing process improvements that will permit safe and compliant operations to continue during the next 5 years, even though $\$ 80$ million was removed from the Environmental Management (EM) program budget. A 2-year analysis, design, and implementation project will reengineer compliance-related activities and reduce operating costs by approximately $\$ 17$ million per year from Fiscal Year (FY) 1998 through 2002, while continuing to meet the INEEL's environment, safety, and health requirements and milestone commitments. Compliance reengineering's focus is improving processes, not avoiding full compliance with environmental, safety, and health laws. In FY 1997, compliance reengineering used a three-phase approach to analyze, design, and implement the changes that would decrease operating costs. Implementation for seven specific improvement projects was completed in FY 1997, while five projects will complete implementation in FY 1998. During FY 1998, the three-phase process will be repeated to continue reengineering the INEEL.
\end{abstract}




\section{SUMMARY}

As a result of the Fiscal Year (FY) 1996 Environmental Management Requirements/Defensible Costs Project (commonly known as the "murder boards") at the INEEL, significant reductions were made in outyear budget requirements. These reductions were accomplished by deleting activities that did not have a solid requirements basis, linking the remaining work directly to that basis, and scrubbing down each task to ensure that it was being accomplished efficiently. As a part of this effort, major site-wide issues that were not solved during the murder board project were identified.

The INEEL took the position that these site-wide issues could be solved with a resulting increase in efficiency. The Environmental Management (EM) program budgets were cut an additional aggregate $\$ 80$ million over the 5-year period, FY 1998 through 2002, and a new project, Compliance Reengineering, was funded at a level of $\$ 5$ million in FY 1997 and $\$ 10$ million in FY 1998. The specific mission of this project is to identify inefficiencies and reengineer EM processes such that the necessary work can be conducted safely and in compliance with applicable rules and regulations, but at a cost of $\$ 80$ million less than was estimated to be required after the murder board effort was completed.

A three-phase approach was selected for the FY 1997 Compliance Reengineering Project activities. Phase 1 (opportunity analysis and selection) was conducted from October through December 1996, Phase II (process redesign) was conducted from January through April 1997 and Phase III (implementation) was conducted from May through September 1997. A similar approach is planned for FY 1998.

A joint Lockheed Martin Idaho Technologies Company (LMTTCO) and Department of Energy Idaho Operations Office (DOE-ID) Compliance Reengineering Team was assembled. A Compliance Reengineering Steering Board of senior LMITCO and DOE-ID managers was designated. Recognizing that changes would have significant cultural and organizational dimensions, in addition to technical solutions, the INEEL partnered with a private firm, Gerald E. Dunn, Inc. (GDI), which has extensive experience integrating these dimensions of change in both the public and private sectors.

Criteria for selection of specific improvement projects included not only a detailed business case that estimated at least a five-to-one benefit-to-cost ratio, but also the individual board members' perceptions of the organization's ability to achieve successful implementation and a personal willingness to participate in the change. On this basis, over sixty potential projects were evaluated and twelve specific improvement projects were selected by the board for final design and implementation. Implementation is in progress or completed for these projects, organized into five work streams (summarized in Table S-1), with the following significant improvements estimated to have avoided costs in excess of \$20 million in FY 1998 and \$100 million in FY 1998 through FY 2002:

- Project Management Systems: Integration and standardization of EM project management processes to include life-cycle planning, EM program office and project manager roles and responsibilities; integrated site-wide scheduling and resource management; software utilization; prioritization of potential projects; project management training; and project and program reporting.

- Safety Analysis: Consistent risk evaluation guidelines for all DNEEL nuclear facilities; improved process for upgrading/updating safety analysis reports (SARs) to reduce unnecessary reviews and 
revisions; and a single electronic data base, allowing access to pre-approved current versions of safety-related documents.

- Occurrence Reporting: Improved fact-finding process; time frame for completing reports; greater use of critiques for near-miss events; improved root cause analysis and lessons learned programs.

- Resource Conservation and Recovery Act (RCRA) Permit Compliance: Significantly reduced cost of compliance with RCRA Part B permit at the Radioactive Waste Management Complex (RWMC) by streamlining training and equipment preventive maintenance processes; use of lessons learned in developing future INEEL facility permits.

- Training: New site-wide guidance that significantly reduces the number of people who are required to attend compliance-related training; improved training delivery methods and techniques.

- Maintenance: Site-wide implementation of Enhanced Work Planning principles for team planning and hazards identification; standard maintenance performance indicators and preventive maintenance optimization; integrated scheduling and maintenance management system.

- Shorten General Plant Projects (GPPs): Team concept utilized at the inception of GPPs to enhance planning, maintain personnel continuity, and optimize the annual construction season; key areas identified to shorten overall time required to design and completed GPPs.

- Integration of Facility Closure: Facility closure process integrated to eliminate multiple transfers of facilities and duplication associated with meeting RCRA and Comprehensive Environmental Response, Compensation, and Liability Act (CERCLA) requirements.

- LMITCO/Parsons Internal Review Process: Integrated process for review and approval of technical documents required for environmental restoration work in which both companies are involved.

- LMITCO/Parsons Project Management Interface: A single line organizational structure that eliminates layered and redundant positions in environmental restoration work; a project control (cost and schedule) interface that creates an electronic link between LMITCO and Parsons baselines, reduces information transfer time, and enhances task agreement process time.

- LMITCO/Parsons Project File and Vendor Management System: A single library system that eliminates duplicate and redundant distribution of documents.

- Environmental Restoration Ad-Hoc Requests: A process that monitors and tracks unplanned requests and the resulting implementation to improve response and followup.

A number of critical factors are identified in order to successfully implement these projects and achieve lasting improvements. The critical success factors requiring constant attention by both LMITCO and DOE-D include the following:

- The necessity of measurable continuous improvement in all processes

- Clearly defining responsibilities of LMITCO as the supplier and DOE-ID as the customer

- Value revolving around project completion, not effort

- Performance measures, rather than budgets, driving the business

- Personal accountability being clearly defined and accepted 
- An effective process being in place for redeployment of personnel throughout the company

- Focusing on applying personal safety first, then safety compliance

- Each person having personal accountability for his or her own safety and the safety of others

- Clearly defining the use of graded approach to compliance

- All activities being tied to the successful delivery of INEEL core products

One of the important components of the Compliance Reengineering Project is to align its objectives with all other ongoing improvement initiatives at the INEEL. This effort has enjoyed some success, but much work remains to be accomplished. In the original analysis, it was discovered that there were over 50 major ongoing improvement initiatives at the INEEL, and that personnel viewed most of them as a "flavor of the month," with no real connection to the overall mission of the INEEL. Significant efforts are now underway to critically examine each initiative, to delete redundant initiatives, and to align those that remain with the overall site-wide objectives. A process to evaluate future improvement initiatives has been recommended for site-wide use. Each new initiative will fill a specific need and fit in a synergistic manner with other ongoing initiatives in order to be accepted.

The disciplined process for selection, design, and implementation of improvement ideas through reengineering appears to be effectively improving the INEEL as a result of this project. Seven FY 1997 specific improvement projects have been completed. Five FY 1997 projects have been approved for continued implementation in FY 1998 at a cost of $\$ 3.3$ million. In addition, the following eleven new FY 1998 projects have been approved at a cost of $\$ 3.5$ million by the Compliance Reengineering Steering Board:

- Enhanced Work Planning

- EM Operations Training Delivery and Administration

- Electronic Drawing Distribution Automation

- Document Distribution Centers

- Environmental Monitoring Consolidation

- INEEL Waste Generator Services Reconfiguration

- Self-Assessment Pilot

- ProCon X Upgrade

- Waste Tracking System

- Systems Engineering

- Material Availability/Warehousing

Other potential projects are being considered and will be reported in the FY 1998 Compliance Reengineering Report. 
Table S-1. Compliance reengineering summary - FY 1997.

\begin{tabular}{|c|c|c|c|c|c|c|}
\hline \multirow[b]{2}{*}{ Stream } & \multirow[b]{2}{*}{ Project } & \multirow[b]{2}{*}{ Existing Conditions } & \multirow[b]{2}{*}{ Reengineering } & \multicolumn{2}{|c|}{ Benefits (\$M) } & \multirow[b]{2}{*}{ Complete } \\
\hline & & & & FY.98 & FY-98-02 & \\
\hline \multirow[t]{2}{*}{ I. Safety } & $\begin{array}{l}\text { Safety Analysis } \\
\text { Reports (SARs) }\end{array}$ & $\begin{array}{l}\text { SAR updates not consistent, too many revised, } \\
\text { process inefficient }\end{array}$ & $\begin{array}{l}\text { Consistent risk evaluations guidelines, streamlined } \\
\text { updates/upgrades process }\end{array}$ & 9.687 & 17.49 & $3 / 31 / 98$ \\
\hline & $\begin{array}{l}\text { Occurrence } \\
\text { Reporting }\end{array}$ & $\begin{array}{l}\text { Usually use critique, may miss root causes, poor } \\
\text { communication of lessons-learned }\end{array}$ & $\begin{array}{l}\text { Investigators conduct investigation, graded use of } \\
\text { critiques, accelerate pre-final OR completion }\end{array}$ & .262 & 1.0 & $9 / 30 / 97$ \\
\hline $\begin{array}{c}\text { II. } \\
\text { Environmental }\end{array}$ & $\begin{array}{l}\text { RCRA Part B } \\
\text { permit }\end{array}$ & $\begin{array}{l}\text { Excessive permit updating, training, preventative } \\
\text { maintenance }\end{array}$ & $\begin{array}{l}\text { Reduce permit requirements, required preventive } \\
\text { maintenance, training }\end{array}$ & .483 & 2.485 & $5 / 31 / 97$ \\
\hline \multirow{2}{*}{ III. Operations } & Training & Excessive training, costly training delivery & Streamline requirements and delivery & 1.33 & 6.645 & $3 / 15 / 98$ \\
\hline & Maintenance & $\begin{array}{l}\text { Redundant procedures, non-value-added } \\
\text { preventive maintenance, inconsistent scheduling, } \\
\text { different work control processes }\end{array}$ & $\begin{array}{l}\text { Standardize scheduling system, optimize preventive } \\
\text { maintenance performance, improve work order } \\
\text { requests, implement standardized performance } \\
\text { measures to maintain improvements }\end{array}$ & 1.403 & 9.257 & $7 / 31 / 98$ \\
\hline \multirow{6}{*}{$\begin{array}{l}\text { IV. Facility } \\
\text { Construction and } \\
\text { Closure }\end{array}$} & $\begin{array}{l}\text { Shorten Project } \\
\text { Time Frame }\end{array}$ & Planning ânud execution costly & $\begin{array}{l}\text { Single LMITCO Project Initiation \& Prioritization } \\
\text { system, project team approach }\end{array}$ & .4 & 2.0 & $9 / 30 / 97$ \\
\hline & $\begin{array}{l}\text { Integration of } \\
\text { Facility Closure }\end{array}$ & $\begin{array}{l}\text { RCRA, CERCLA, FDI closure activities not } \\
\text { integrated }\end{array}$ & Integrate closure activities, eliminate duplication & .12 & 3.7 & $9 / 30 / 98$ \\
\hline & $\begin{array}{l}\text { LMITCO/Parsons } \\
\text { Review Process }\end{array}$ & Redundant reviews & $\begin{array}{l}\text { Eliminate one Parsons review cycle and reduce } \\
\text { participation in the IRC process }\end{array}$ & .3 & 1.475 & $9 / 30 / 97$ \\
\hline & $\begin{array}{l}\text { LMITCO/Parsons } \\
\text { Project } \\
\text { Management (PM) } \\
\text { Interface }\end{array}$ & Duplicate positions, roles, and responsibilities & $\begin{array}{l}\text { Eliminate duplication, org. structure for PM, software } \\
\text { and effort for project controls }\end{array}$ & 2.242 & 11.21 & $9 / 30 / 97$ \\
\hline & $\begin{array}{l}\text { LMITCO/Parsons } \\
\text { Project File/Vendor } \\
\text { Data Management }\end{array}$ & $\begin{array}{l}\text { Duplicate organizations, excessive volume, } \\
\text { inefficient process }\end{array}$ & Single vendor data, one document system, one library & .183 & .914 & 9/30/97 \\
\hline & $\begin{array}{l}\text { Environmental } \\
\text { Restoration Ad } \\
\text { Hoc Requests }\end{array}$ & Inefficient ad hoc request process & $\begin{array}{l}\text { Screen and track ad hoc requests, eliminating } \\
\text { duplicate effort for responses }\end{array}$ & .15 & .8 & 9/30/97 \\
\hline $\begin{array}{l}\text { V. Business/ } \\
\text { Project } \\
\text { Management }\end{array}$ & $\begin{array}{l}\text { Project } \\
\text { Management } \\
\text { Systems }\end{array}$ & $\begin{array}{l}\text { Project management process and system not } \\
\text { standardized; several project management } \\
\text { software packages used in EM; no PM roles and } \\
\text { responsibilities; no PM career path; project } \\
\text { manager job title applied with no specific criteria }\end{array}$ & $\begin{array}{l}\text { Standardize PM processes by life-cycle planning, } \\
\text { program office; implement one project management } \\
\text { software as EM standard; establish specific project } \\
\text { manager roles and responsibilities; establish project } \\
\text { manager advisory board to establish and maintain } \\
\text { criteria for project managers; establish PM job family }\end{array}$ & 3.9 & 43.1 & $5 / 98$ \\
\hline TOTAL & & & & 20.46 & 100.076 & \\
\hline
\end{tabular}




\section{ACKNOWLEDGMENTS}

The Compliance Reengineering Project would like to express appreciation to those who assisted with the project and this report.

LMTCO President: W. J. Denson DOE-ID Manager: J. M. Wilcynski

Executive Sponsors: G. E. Ellis, LMITCO

J. L. Lyle, DOE-ID

Project Managers: J. N. Davis, LMITCO

L. L. Fritz/M. Schultz, DOE-ID

Compliance Reengineering Steering Board - J. A. VanVliet -VP EM, Chairman

LMITCO: W. A. Baxter

K. L. Falconer

J. E. Hovinga

A. M. Jensen

T. H. Judd
S. A. Scobby

T. A. Mathews

M. J. Wolters

P. S. Yela
DOE-ID: W. H. Leake

G. L. Beausoleil

J. T. Case
P. J. Dirkmaat

N. R. Jensen

R. A. Taft

\section{Senior Management Advisors}

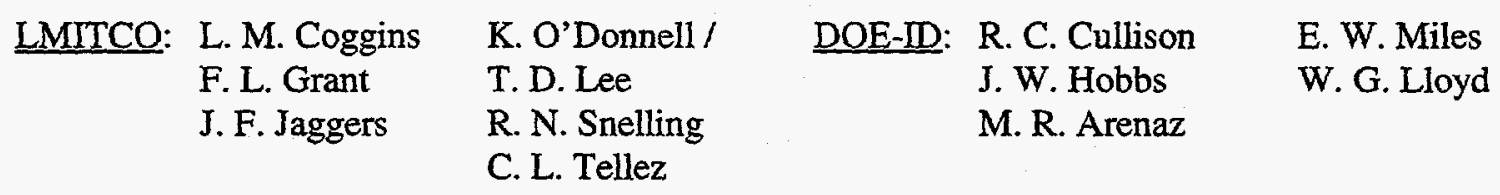

Environmental Stream

C. L.. Tellez - LMTTCO Champion J. T. Case - DOE-ID Advocate $\quad$ R. Y. Maughan - Stream Lead RCRA Part B Team - R. Y. Maughan, Leader
D. L. Forsberg
J. R. Mitchell
P. A. Sloan
B. M. Angle
J. M. Jackson

\section{Safety Stream}

T. A. Mathews - LMITCO Champion T. L. Wichmann - DOE-ID Advocate J. I. Pruitt - Stream Lead Safety Analysis Reports Team - J. I. Pruitt, Leader
S. J. Bengston
E. E. Hochhalter
T. A. Mathews
R. G. Peatross
W. H. Sullivan
K. S. Butler
J. E. Johnson, Jr.
W. A. Mickelson
A. G. Ramos
T. A. Tomberlin
N. E. Cole
L. J. Larsen
R. L. Nitschke
L. C. Seward
F. C. Traxler
L. A. Decker
L. G. Lee
N. C. Olson
T. W. Smith
T. L. Wichmann

J. M. Erickson

Occurrence Reporting Team - J. I. Pruitt, Leader
H. Ashley
G. L. Courtney
V. R. Keele
L. C. Mitchell
R. C. Seal
G. L. Branson
J. L. Hopla
R. O. Laing
C. Landgraver
C. S. Olson
O. K. Steinmetz
C. D. Brooks
D. C. Jenkins
N. D. Rohrig
T. L. Wichmann 


\section{Operations Stream}

M. J. Wolters, LMITCO Champion $\quad$ G. L. Beausoleil, DOE-ID Advocate $\quad$ R. Y. Maughan, Stream Lead Maintenance Team - J. B. Quick, Leader
M. L. Fife
M. F. Ruenger
R. Wilson
K. Young
R. L. Jones
P. Trosclair
J. R. Wixson

Quality Assurance Team - M. T. Watts, Leader

Training Team

Phase I, II: M. J. Wolters, LMITCO Champion

R. Y. Maughan, Stream Lead

Team Leader: G. L. Branson (I), C. A. Glavin (II)
B. M. Angle
G. E. Hinsley
M. T. O'Connor
J. A. Rindfleisch
E. F. Armstrong
B. T. Hobbs
J. M. Pechtel
P. T. Scobby
J. Bewick
F. H. Holmes
L. W. Peterson
L. Sehlke
L. A. Chapman
D. Hymer, consultant
R. L. Shelton-
P. Trosclair
C. B. Crandall
J. S. Irving
Davis
S. D. Croft
R. A. Lopez
A. G. Ramos
M. A. Verdoorn
M. A. Ehlinger
L. P. Murphy
R. E. Remsburg
R. Wilson

Phase III: J. E. Hovinga, LMTCO Champion

J. I. Pruitt, Stream Lead

C. A. Glavin, Team Leader

Core Reengineering Team:

C. A. Glavin

J. I. Pruitt

R. Y. Maughan

R. Wilson

Operations:

R. R. Chase

N. K. Winter

N. K. Dyet

J. E. Kaylor

T. L. Clements

Regulatory/Legal:

T. O. Bodily

T. Lewis

D. L. Puccinelli

W. C. Craft

W. S. Schum

J. H. Piper

Training:

B. Cornell

C. B. Crandall

S. Theobald James

G. E. Hinsley
B. G. Berry

J. M. Welch

A. D. Grow

T. S. Schietinger

C. E. Hunsaker

G. T. Paulson

J. D. Downes

G. L. Courtney

C. H. O'Donnell

J. L. Standfield

R. C. George

M. T. O'Connor

W. R. George
J. Bewick

P. A. Thome

R. Jones

W. W. Gay

R. A. Bull

L. D. Lindberg

D. H. Mason

R. Stearns

L. Blair

W. Nelson
C. Jones

T. Brunson

J. D. Hops

J. C. Kent

F. Holmes

J. M. Pechtel

L. P. Murphy

M. A. Verdoom

T. L. Mockli
P. Creighton

J. Mitchell

K. Gilbert

$B$. Angle

Electrical Safety Committee
A. B. Pearson
S. Willford
L. Peterson
P. Barnes 


\section{Facility Construction and Closure Stream}
K. L. ER Ad Hoc Requests Team - C. J. Scott, Leader
R. G. Barnette
D. D. Shafer
D. C. Fountain

Integration of Facility Closure Team - B. J. Frazee, Leader
S. R. Martinson
D. H. Preussner
S. Rush, Rocky Mountain Engineering
C. S. Mascarenas
B. T. Richards

LMITCO/Parsons Internal Review Process Team - J. P. Shea, Leader
J. D. Dustin
D. C. Fountain

LMITCO/Parsons Vendor and Data Management Systems Team - D. C. Fountain, Leader
K. R. Croft
G. Johnson
R. M. Peterson
C. Finch
M. A. Poole, Parsons
J. Rothermal, Parsons

LMITCO/Parsons Project Management Interface Team - D. C. Fountain, Leader
D. S. Carlson
T. K. Pearson
R. Wuska, Rust
L. M. Higgins
C. B. Roth, Parsons
J. D. Yeates

Shorten Project Time Frame Team - T. Schietinger, Leader (J. I. Pruitt, Stream Lead)
V. C. Archibald
B. C. Doutt
T. A. Langenwalter
S. L. Palmer
M. B. Lapioli
J. D. Poole
K. J. Steed
D. S. Behrens
D. M. Flynn
D. J. Oakey
B. P. Summers
R. L.
G. W. Boge
A. A. Grow

\section{Business/Project Management Stream}

S. A. Scobby - LMTCO Champion

R. L. Moore - Stream Lead, Phase I

C. R. Fry, Stream Lead, Phase III
M. R. Arenaz - DOE-ID Advocate

R. J. Bargelt - Stream Lead, Phase II

Phase I: B. Addison

K. J. Dooley

J. L. Burns

B. G. Edgerton

R. L. Moore

T. Schietinger

P. A. Thorne

H. B. Wooley

Phase II: Project Management Job Family Team - J. J. McCarthy, Leader
F. C. Cowart
O. V. Hester
M. A. Keister
B. K. Ford
J. F. Jaggers
C. J. Maheras
W. B. McNaught

Project Management Software Team - D. A. Baird, Leader
J. E. Bramlett
G. E. Matthern
D. D. Shafer
M. L. Nelson
K. C. Throop
J. H. Timmons
M. Wiest

Project Management Systems Team - J. C. Baker, Leader
L. M. Birkinbine
D. A. Groetzinger
R. A. Schiffern
J. L. Tripp
M. P. Hodel 


\section{Business/Project Management Stream (continued)}

Phase III: Project Management Software Team - D. A. Baird, Leader
J. E. Bramlett
M. L. Nelson
D. D. Shafer
R. Jones
D. Rapp
K. C. Throop
J. H. Timmons
G. E. Matthern

Project Management Systems Team - C. R. Fry/ D. A. Groetzinger, Leaders

\section{LMITCO}

S. M. Edgett

D. C. Fountain

B. L. Griebenow

A. B. Hubbard

\section{DOE-ID}

J. L. Burns

W. D. Lewis

A. M. Obray$$
\text { A. M. Obray }
$$

GDI

B. P. King

B. J. Lilburn

J. H. Timmons

G. R. Barnes

S. M. Buchwald

P. A. Thorne

\section{Change Management Governance Team}

J. N. Davis/E. Parsons, Leaders

S. S. Francis / K. Gatens, Communication/Mobilization

K. K. Koch, Benefits Tracking

L. A. Sehlke, Initiative Alignment

C. J. Smith, Administration

\section{Gerald Dunn, Inc. - Technical Support}

\author{
S. Panos, Team Leader \\ B. Addison \\ J. Bewick \\ G. R. Barnes \\ S. M. Buchwald
}
A. Dunn
D. Gennrich
S. C. Hyde
T. Jeffcoat
W. Powell
J. Romeyn
P. A. Thorne
R. Kingsnorth

Technical writing/editing support for this report: J. G. Bradley 


\section{CONTENTS}

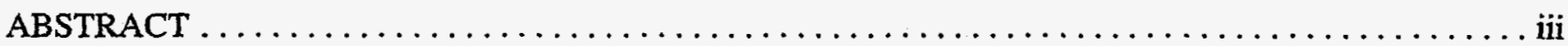

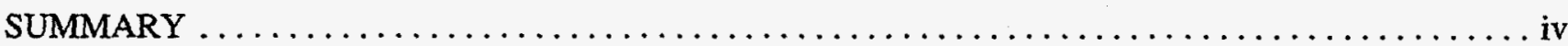

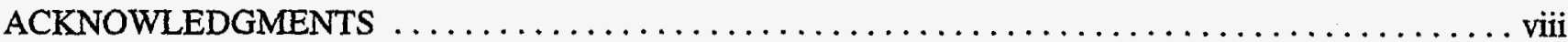

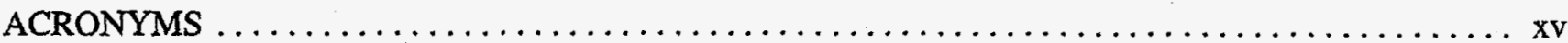

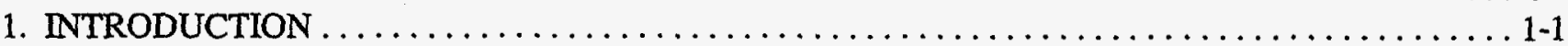

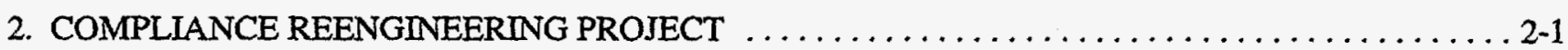

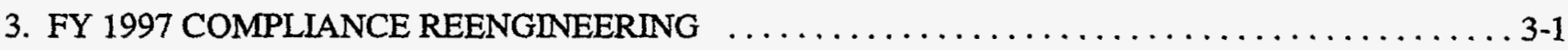

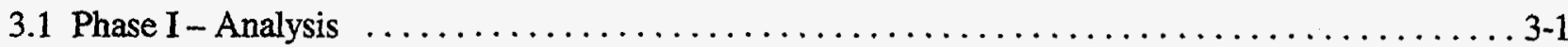

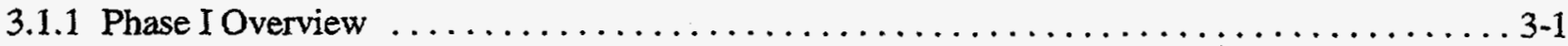

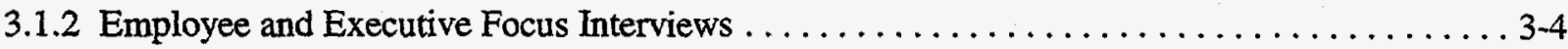

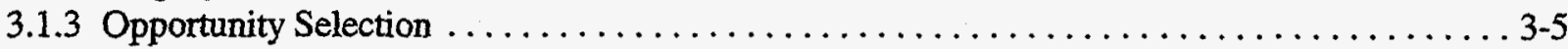

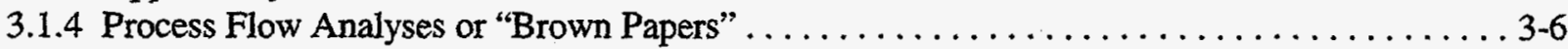

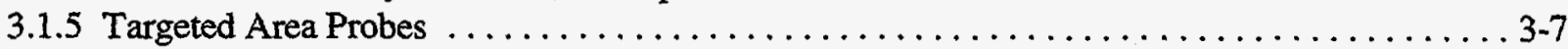

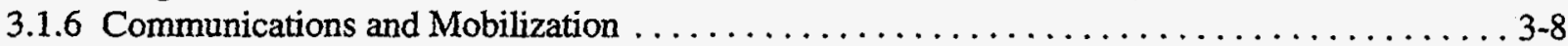

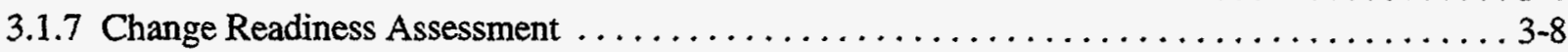

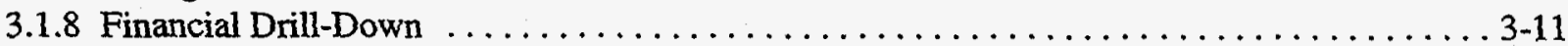

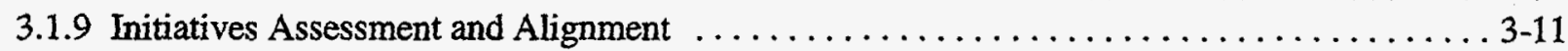

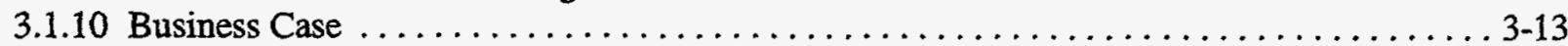

3.1.11 Project Selection Using the $2^{2} 4^{2}$ Process Reengineering Decision Matrix ${ }^{\text {SM }} \ldots \ldots \ldots \ldots .13$

3.2 Phase I Selected Improvement Projects for FY $1997 \ldots \ldots \ldots \ldots \ldots \ldots \ldots \ldots \ldots \ldots \ldots$

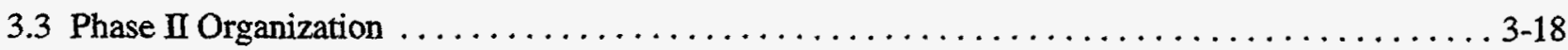

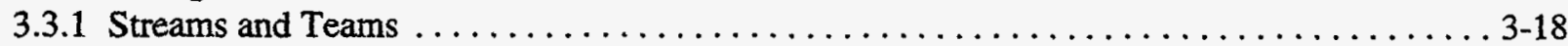

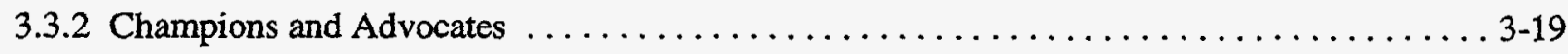

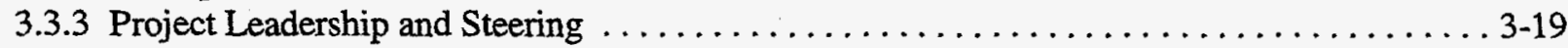

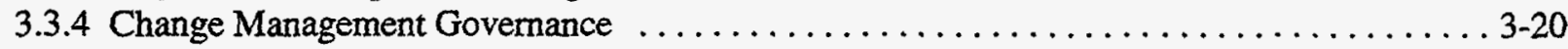

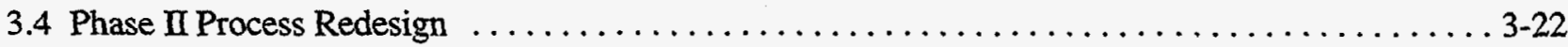

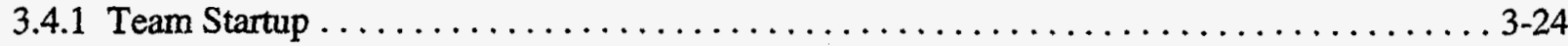

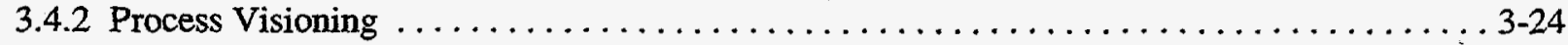

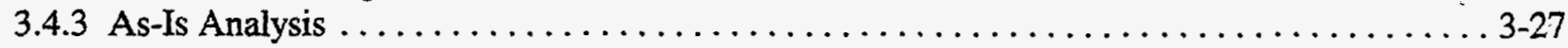

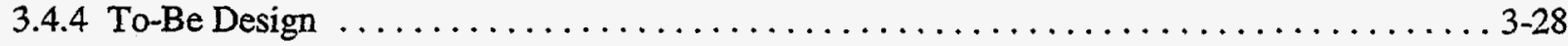

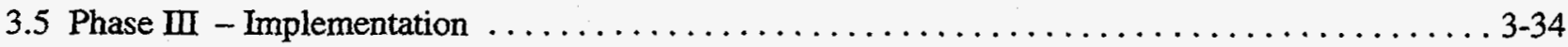

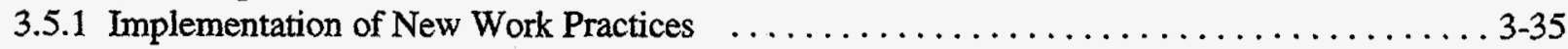

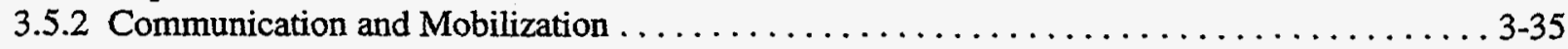

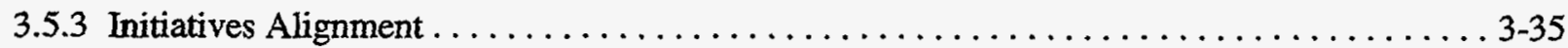

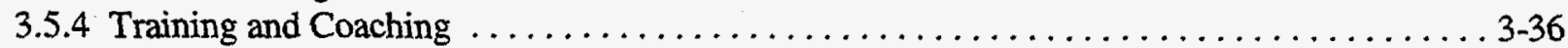

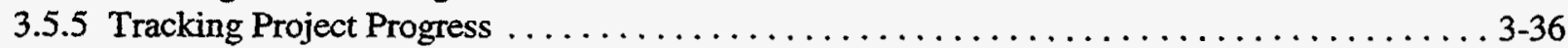

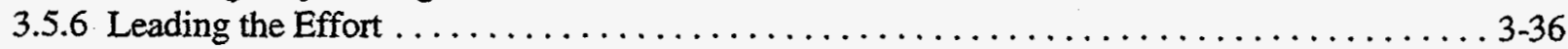

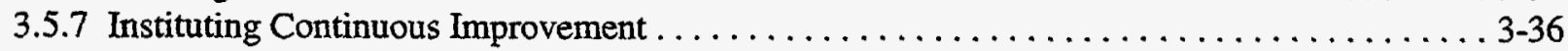


4. SPECIFIC FY 1997 IMPROVEMENT PROJECTS $\ldots \ldots \ldots \ldots \ldots \ldots \ldots \ldots \ldots \ldots \ldots \ldots \ldots \ldots$

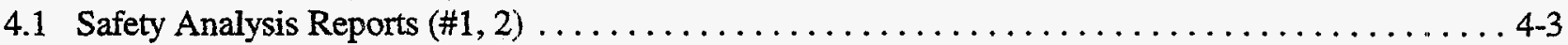

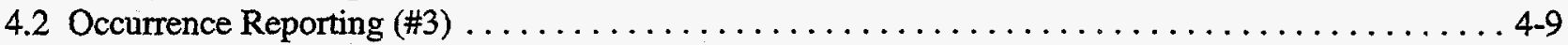

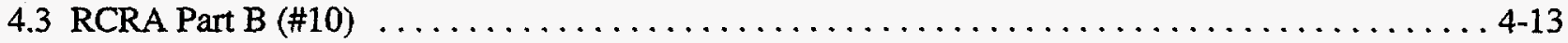

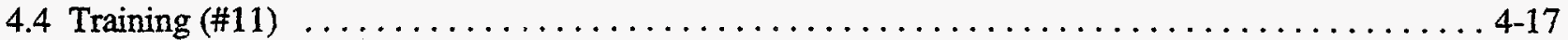

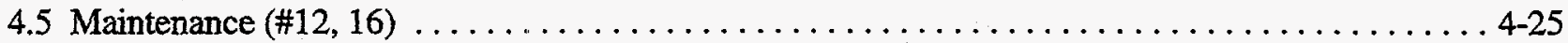

4.6 Shorten General Plant Project (GPP) Time Frame $(\# 18,19 c) \ldots \ldots \ldots \ldots \ldots \ldots \ldots \ldots \ldots$ 4-30

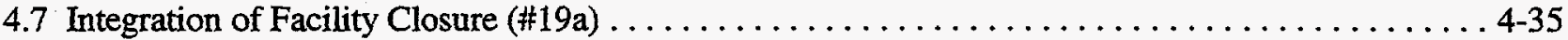

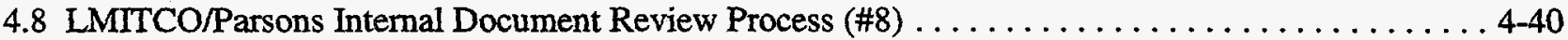

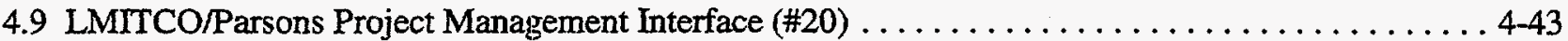

4.10 LMITCO/Parsons Project File and Vendor Data Management Systems (\#21) . . . . . . . . 4-45

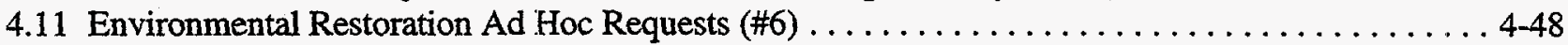

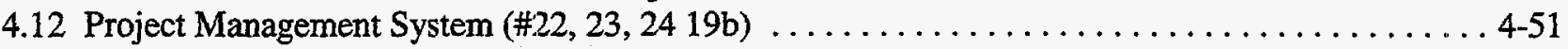

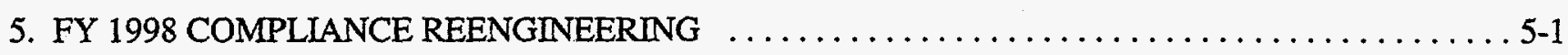

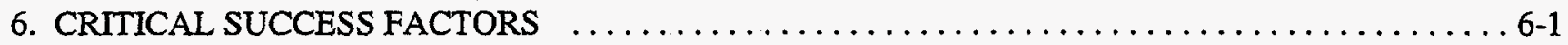

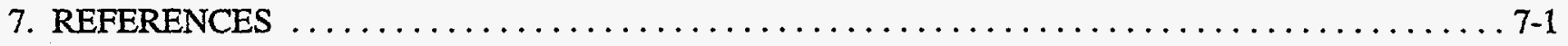

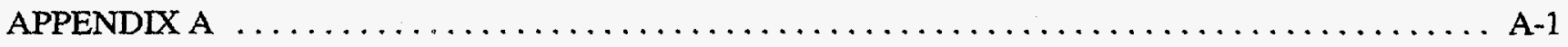

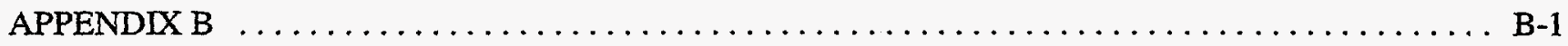

\section{FIGURES}

Figure 1-1. Rational, political, and emotional responses to change $\ldots \ldots \ldots \ldots \ldots \ldots \ldots \ldots \ldots \ldots \ldots$

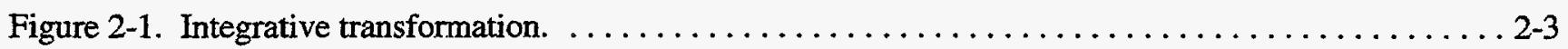

Figure $3-1$. Overview of INEEL compliance reengineering $\ldots \ldots \ldots \ldots \ldots \ldots \ldots \ldots \ldots \ldots \ldots \ldots \ldots \ldots \ldots \ldots .2$

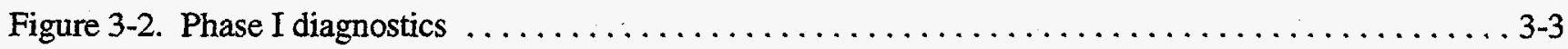

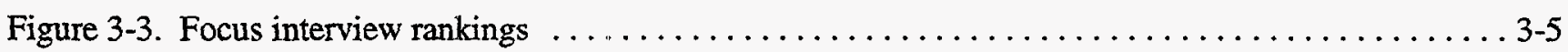

Figure 3-4. Brown paper illustrating the work process on wall-sized brown paper. $\ldots \ldots \ldots \ldots \ldots \ldots$

Figure 3-5. Addressing key questions to drive the INEEL forward to successful change $\ldots \ldots \ldots \ldots \ldots 3-10$

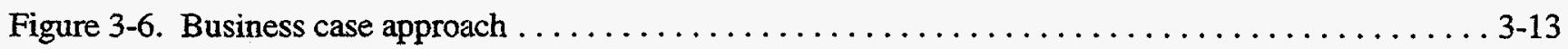

Figure $3-7.2^{2} 4^{4}$ matrix: projects with highest chance of success and value $\ldots \ldots \ldots \ldots \ldots \ldots \ldots \ldots$

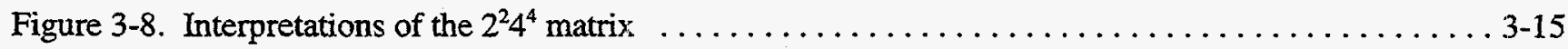

Figure 3-9. Structured framework of compliance reengineering. $\ldots \ldots \ldots \ldots \ldots \ldots \ldots \ldots \ldots \ldots \ldots$

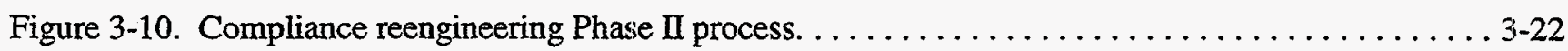


Figure 3-11. War room charts and documentation.

Figure 3-12. Team charter with project members, purpose, scope, and deliverables.

Figure 3-13. Process visioning.

Figure 3-14. Project theme and objectives of the project.

Figure 3-15. Responsibility matrix - project and implementation roles.

Figure 3-16. Compliance reengineering projects and work stream relationships chart.

Figure 3-17. Project integration chart.

Figure 3-18. Project critical success factors chart.

Figure 3-19. Project performance metrics - measuring the to-be process during implementation.

Figure 3-20. Benefits delivery commitment - quantitative and qualitative cost benefit. 3-30

Figure 3-21. Benefits delivery commitment detail for each quantifiable recommendation.

Figure 3-22. Components of change chart showing the as-is and to-be processes.

Figure 3-23. DACI (doer, accountable, consult, inform) chart showing to-be process roles.

Figure 3-24. Phase III compliance reengineering.

Figure 3-25. Initiatives alignment.

Figure 3-26. Evaluating initiatives

\section{TABLES}

Table S-1. Compliance reengineering summary - FY $1997 \ldots \ldots \ldots \ldots \ldots \ldots \ldots \ldots \ldots \ldots \ldots \ldots \ldots$

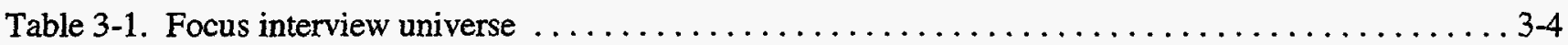

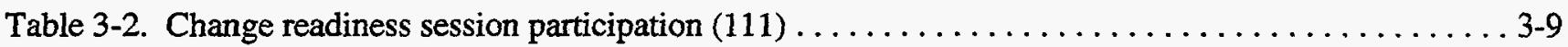

Table 3-3. INEEL change readiness enabling scores $\ldots \ldots \ldots \ldots \ldots \ldots \ldots \ldots \ldots \ldots \ldots \ldots \ldots \ldots$

Table 3-4. FY 1997 compliance reengineering potential and selected projects . . . . . . . . . . 3-16

Table 4-1. Compliance reengineering summary - FY $1997 \ldots \ldots \ldots \ldots \ldots \ldots \ldots \ldots \ldots \ldots \ldots \ldots \ldots$

Table $5-1$. FY 1998 potential and selected projects $\ldots \ldots \ldots \ldots \ldots \ldots \ldots \ldots \ldots \ldots \ldots \ldots \ldots \ldots \ldots \ldots \ldots \ldots .2$

Table 5-2. Compliance reengineering projects selected for FY $1998 \ldots \ldots \ldots \ldots \ldots \ldots \ldots \ldots \ldots \ldots$ 


\section{ACRONYMS}

\begin{tabular}{|c|c|}
\hline ADS & activity data sheets \\
\hline ARDC & administrative record and document control \\
\hline $\mathrm{BCP}$ & baseline change proposal \\
\hline $\mathrm{CCB}$ & change control board \\
\hline CEP & capital equipment projects \\
\hline CFR & Code of Federal Regulations \\
\hline CERCLA & Comprehensive Environmental Response, Compensation, and Liability Act \\
\hline CFA & Central Facilities Area \\
\hline CMMS & computer maintenance management system \\
\hline CPAF & Cost Plus Award Fee \\
\hline $\mathrm{D} \& \mathrm{D}$ & decontamination and dismantlement \\
\hline DACI & doer, accountable, consult, inform \\
\hline DEQ & Department of Environmental Quality \\
\hline DOE & Department of Energy \\
\hline DOE-WD & Department of Energy Idaho Operations Office \\
\hline EM & Environmental Management \\
\hline EPA & Environmental Protection Agency \\
\hline ER & Environmental Restoration \\
\hline ERPC & Environmental Restoration Project Control \\
\hline $\mathrm{ES} \& \mathrm{H}$ & environment, safety, and health \\
\hline FDI & Facility Disposal Initiative \\
\hline FTE & full-time equivalent \\
\hline FY & fiscal year \\
\hline GDI & GDI Consulting and Training Company, a division of Gerald E. Dunn, Inc. \\
\hline GPP & general plant projects \\
\hline HWMA & Hazardous Waste Management Act \\
\hline ICARE & Issues Communication and Resolutions Environment \\
\hline ICPP & Idaho Chemical Processing Plant \\
\hline IDHW & Idaho Department of Health and Welfare \\
\hline ILTSF & intermediate-level transuranic storage facility \\
\hline MMED & Issues Management Electronic Database \\
\hline INEEL & Idaho National Engineering and Environmental Laboratory \\
\hline $\mathbb{R} \mathbf{R}$ & Independent Review Committee \\
\hline ITMC & INEEL Training Management Council \\
\hline LCAM & life cycle asset management \\
\hline LMTTCO & Lockheed Martin Idaho Technologies Company \\
\hline LQST & LMITCO Quality Steering Team \\
\hline $\mathrm{MCP}$ & management control procedure \\
\hline NEPA & National Environmental Policy Act \\
\hline NOD & notice of deficiency \\
\hline OBS & organization breakdown structure \\
\hline OEFP & operating expense funded projects \\
\hline OIS & optical imaging system \\
\hline OR & occurrence report \\
\hline ORPS & Occurrence Reporting Processing System \\
\hline PBS & project breakdown structure \\
\hline $\mathrm{P} / \mathrm{CM}$ & Project/Construction Management \\
\hline PM & preventive maintenance \\
\hline
\end{tabular}


PM project management

QA quality assurance

RCRA Resource Conservation Recovery Act

RWMC Radioactive Waste Management Complex

SAR safety analysis report

SSC system, structure, and component

TAN Test Area North

TRA Test Reactor Area

TSR technical safety requirement

WAG waste area group

WSF waste storage facility

WERF Waste Experimental Reduction Facility

WROC Waste Reduction Operations Complex 


\section{Environmental Management Compliance Reengineering Project FY 1997 Report}

\section{INTRODUCTION}

During 1996, the Environmental Management (EM) Program at the Idaho National Engineering and Environmental Laboratory (INEEL) implemented a comprehensive review of top-level requirements and the out-year cost estimates. The Environmental Management Requirements/Defensible Costs Project (commonly known as the "murder boards") was actively supported by all organizations of the operating contractor, Lockheed Martin Idaho Technologies Company (LMITCO), and the Department of Energy Idaho Operations Office (DOE-ID). Subsequently, the INEEL established the EM Directors Board to address issues raised by the murder boards. The EM directors' effort to resolve major EM issues provided an additional impetus for reengineering. During 1996 and 1997 there was an ever-increasing recognition that larger, cross-organizational issues were not going to be expeditiously solved without a comprehensive project focus. The initial reengineering step was the workshop held for a group of approximately 20 INEEL personnel in mid-1996. The analysis done in the workshop highlighted the need to focus on high-priority reengineering candidates such as: budgeting, project management and infrastructure support.

The Compliance Reengineering Project is the innovative approach to achieving significant productivity gains through process redesign. The INEEL chose compliance-related functions as the target for increasing productivity because senior DOE-ID and LMITCO management determined that more effective implementation of compliance-related requirements could save an aggregate of $\$ 80$ million in FY 1998 through 2002 while not adversely affecting the INEEL's environmental, safety, and health posture or its milestone commitments. The intent is to comply with external laws, rulings, agreements, and policy in a more consistent manner and reduce excess compliance buffers. Therefore, the EM activity data sheets (ADS) for FY 1998-2002 were reduced by $\$ 80$ million in operating costs, and the FY 1997-1998 ADS included the $\$ 15$ million investment required to fund the 2-year project. During FY 1997 and 1998, the Compliance Reengineering Project will make the senior management's planned $\$ 80$ million reduction in operating costs a programmatic reality.

Reengineering was selected as the methodology because successfully redesigning processes entails radical change in the technical, cultural, and organizational dimensions. While the implementation of previous INEEL projects tended to focus exclusively on the technical, the implementation obstacles encountered were primarily caused by cultural and organizational factors. To conduct the Compliance Reengineering Project, LMITCO and DOE-ID partnered with a private-sector firm, GDI Consulting and Training Company, a division of Gerald E. Dunn, Inc. GDI has extensive experience integrating the technical, cultural, and organizational dimensions of change in both the public and private sectors. GDI also brought the perspective of an outsider accustomed to working with and thinking like industry.

GDI and the INEEL customized the basic reengineering strategy. The following dimensions of change are the foundation of the customized strategy:

Technical: The new tools, procedures, processes, and policies. 
Cultural: The mind shift to a new DOE-LMITCO relationship. DOE, as the customer, specifies requirements and the desired outcomes. LMITCO, as the supplier, meets those requirements and achieves those outcomes in the most effective manner possible.

Organizational: The management of the change in people's roles and the work content.

To conduct the strategy, the roles of the project team and senior leadership were defined. The Compliance Reengineering Project team would focus on the technical dimensions of change and conduct some of the activities necessary to achieve cultural and organizational change. The senior management team would be involved in some of the technical decisions, but would focus their efforts on the cultural mind shift and organizational changes necessary for reengineering to succeed. The Compliance Reengineering Project's push for change was expected to invoke three responses in employees-rational, political, and emotional. See Figure 1-1 for a view of the responses.

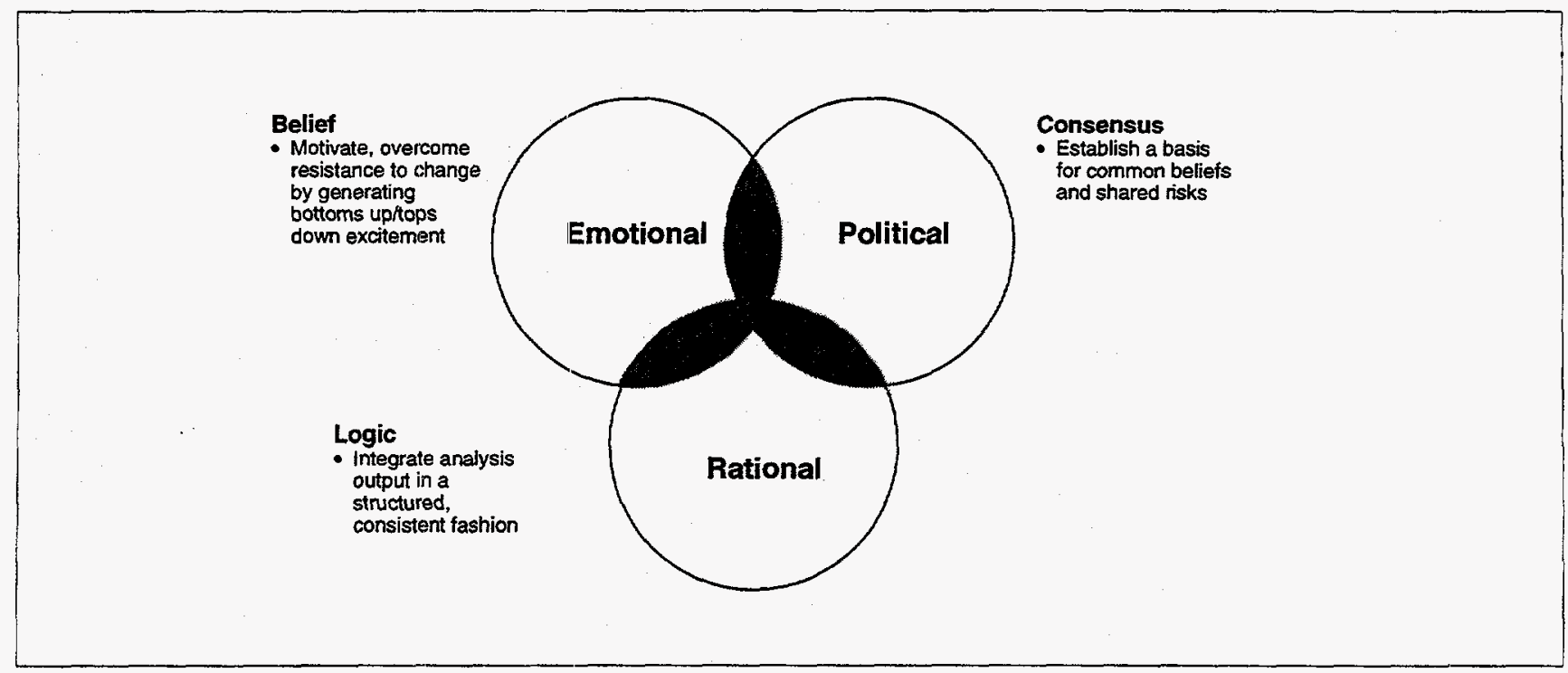

Figure 1-1. Rational, political, and emotional responses to change.

The technical reengineering project approach addresses the needs of those people whose dominant response is rational. Since most people respond emotionally or politically, the overall strategy has to overcome their non-technical responses for reengineering to succeed. Actions are designed to deal with the emotions created by job insecurity and community concerns. Other planned actions address the political aspect of change, the power base changes, and the perception of changes in power both inside the INEEL and in the larger community. 


\section{COMPLIANCE REENGINEERING PROJECT}

The Compliance Reengineering mission is to reduce the FY 1998-2002 Environmental Management Program's operating costs by an aggregate of $\$ 80$ million through the redesign of compliance-related processes while not adversely affecting the INEEL's environmental, safety, and health posture or its milestone commitments. The Compliance Reengineering Project is funded for \$5 million in FY 1997 and $\$ 10$ million in FY 1998.

To successfully achieve the required change, the EM directors selected a disciplined reengineering approach. The FY 1997 reengineering project is divided into three phases:

Phase 1. Assessment and analysis; selection of improvement projects for FY 1997.

Phase II. Detailed design and beginning implementation for improvement projects.

Phase III. Completing implementation of improvement projects; benefits measurement.

The FY 1998 activities will include measurement of the performance improvements resulting from FY 1997 implementation, completion of projects begun in FY 1997, and the selection, design, and implementation of additional projects for FY 1998.

LMITCO and DOE-ID partnered with GDI Consulting and Training Company, a division of Gerald E. Dunn, Inc., to assist with the integrative business transformation process. Facilitation by an outside firm was critical because the INEEL wants to increase its ability to run the EM Program and related support functions like a business. GDI brings a particular strength in addressing the organizational, as well as cultural and technical, performance barriers. GDI was selected through a competitive bid process on the basis of its experience with similar transformations in both public and private organizations. A cross-functional team of 33 LMITCO, DOE-ID, and GDI personnel conducted the Phase I compliance reengineering activities. The Compliance Reengineering Steering Board was established to provide the joint senior management leadership. The steering board consists of nine LMITCO EM directors, four DOE-ID program managers, and three DOE-ID facility managers. The steering board is chaired by the LMITCO Vice President for Environmental Management.

Recognizing that many of the issues would be complex and require integration of several organizations, the reengineering project was undertaken with the wide support and participation of LMITCO and DOE-ID. It was agreed that the project would include focused evaluations, using tools such as value engineering, worksmart standards, life-cycle planning, business process reengineering, etc. These tools provide the technical basis for changes in policies, procedures, technical specifications, and other operational processes. The reengineering process was designed to be flexible and adaptive. Information gained in the early stages would help define the specific approach for subsequent activities. The project steps were tailored to the reality of the situations being evaluated.

The compliance reengineering project strategy was based on experience-to effectively change long-standing practices and achieve lasting cost savings, solutions must address the technical, cultural, and organizational dimensions of change. The compliance reengineering team used a variety of diagnostic tools with a dual purpose - to assist in the data gathering and to contribute to the mobilization of personnel. Multiple diagnostics were used to evaluate issues and address the relevant concerns from more than one perspective. Rational logic and analysis output were incorporated in a structured fashion. Diagnostics measured the attitudes 
of the INEEL population and initiated their mobilization. To motivate people, overcome the resistance to change, and generate support at all levels, the diagnostics included an increasing number of employees. Experience proves that employee involvement in the process leads to mobilization and advocacy by those individuals with the responsibility to implement the change. The need to establish political consensus, common beliefs, and a sense of shared risks was addressed through communication. Regular progress reviews with the Compliance Reengineering Steering Board were held to ensure continuing management leadership and continuity of purpose. The overheads from these briefings are stored in the project files.

The early analysis identified potential reengineering projects that met the following criteria:

- Improved performance in a compliance-related function will require changes in interpretation of requirements or the redesign of internal procedures, processes, or organizations.

- Project implementation will result in at least a 5:1 benefit to cost ratio.

- Stakeholders believe there is a high potential for successful implementation.

- The INEEL will comply with requirements as written or formally established.

The compliance reengineering teann and GDI used a process called integrative transformation (illustrated in Figure 2-1). Integrative transformation changes the fundamental conduct of Environmental Management processes at the INEEL and develops the following values and attributes:

- Empowerment - resulting from giving clear direction to the path forward and delegating authority

- Enthusiasm - resulting from providing clear vision and specific goals and greater authority

- Trust - resulting from providing clear purpose and delegating responsibility

- Courage - to achieve goals and overcome obstacles to change

- Credibility - resulting from following through on commitments

- Integrity - resulting from doing things for the right reason, focusing on performance goals, not budgets.

These values and attributes promote a climate of self-correction and individual initiative, encourage individual and team initiative, and provide the foundation for dramatic and significant change. 


\section{INTEGRATIVE TRANSFORMATION}

Integrative transformation is the process of rapidly moving a company from one operating dimension to another.

Integrative transformation results in dramatic change in:

- Cost

- Quality

- Service

- Resources

Integrative transformation requires high levels of process innovation while at the same time understanding limitation and opportunities set by markets, technology, the business environment and the company's capabilities.
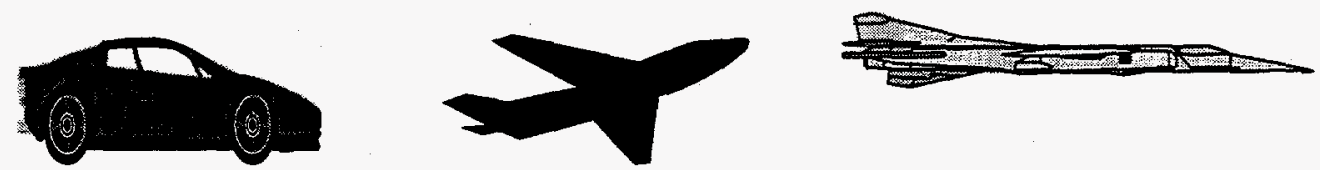

Figure 2-1. Integrative transformation. 


\section{FY 1997 COMPLIANCE REENGINEERING}

The FY 1997 reengineering project is divided into three phases:

Phase I (October 28-December 23, 1996). Opportunity assessment, business analysis, initial employee mobilization, project selection, conceptual design of improvement projects for FY 1997, and path forward project design.

Phase II (January 8-April 30, 1997). Detailed project design, broad mobilization, start of implementation for improvement projects, and path forward for implementation

Phase III (May 1-September 30, 1997). Completion of the selected improvement projects, benefits measurement, and documentation.

\subsection{Phase I Process}

The objectives of Phase I were to conduct the analysis, develop the conceptual design for the reengineering of processes to achieve the desired 5:1 benefits to cost ratio, and begin the employee mobilization. The Phase I process included multiple activities aimed at understanding how compliance-related work is now accomplished, evaluating organizational readiness for change, assessing other initiatives, and defining opportunities for improvement.

The Phase I reengineering process required involvement from significant numbers of INEEL employees and initiated the broader mobilization and support for change. The business analysis validated known issues, documented the discoveries, and assessed new opportunities in terms of economics and probability of successful implementation. The project plan for each reengineering opportunity defined the specific approach and implementation schedule. The business case defined the reengineering benefits, return on investment, and stakeholder value for the opportunities recommended as the best options for achieving the cost-reduction target. The Compliance Reengineering Steering Board evaluated the Phase I findings and business case to select the specific projects for Phases II and III. The project team tailored the path forward strategy to the selected opportunities and the level of the organization's readiness for change. Figure 3-1 shows the process from issue development to reengineering implementation.

\subsubsection{Phase I Overview}

The Phase I reengineering process involved several hundred people from EM and the support organizations within LMITCO and DOE-ID. Initially, the subteams were structured to focus on three major areas:

- Site processes and procedures: operational, safety, and environmental opportunities

- Business management practices: budgeting, program management and tracking, and reporting opportunities

- Business case and organization assessment: financial analysis and benefits quantification, assessment of people issues. 


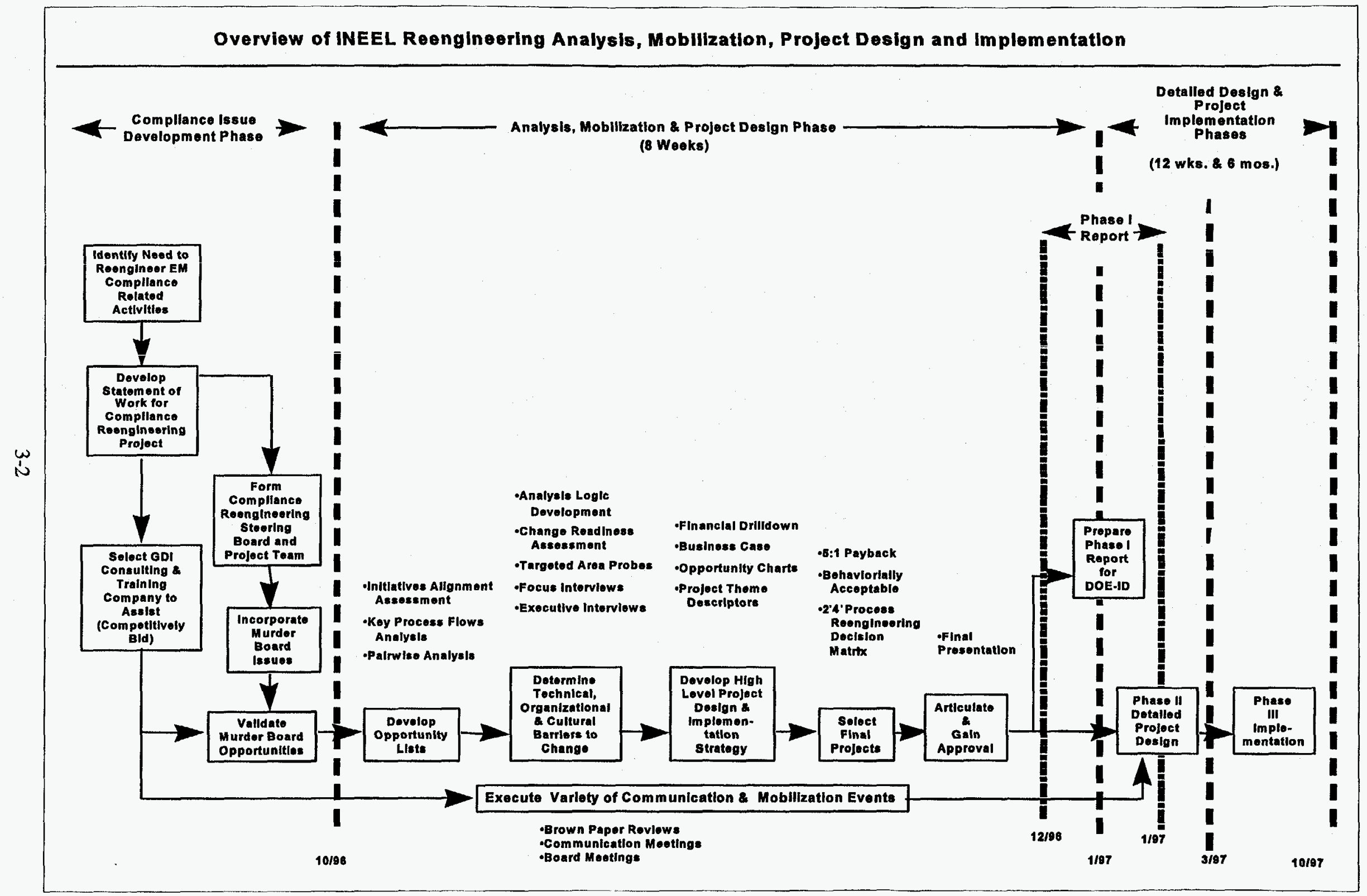

Figure 3-1 Overview of INEEL Compliance Reengineering. 
The sub-teams evaluated how compliance-related work was being accomplished and made recommendations for improvements. Core business process redesign opportunities were selected by the following process:

- Examining and analyzing requirements, and comparing those requirements to actual implementation in the field.

- Analyzing possible process improvements and developing the business case, including the costs of implementing potential reengineering projects and their financial benefits.

- Analyzing present attitudes and beginning to mobilize the personnel associated with the processes, in order to successfully implement the projects selected for Phases II and III.

- Developing the basic redesign of the selected processes.

Multiple reengineering diagnostics were performed simultaneously. The key Phase I diagnostics are illustrated in Figure 3-2. For each of the diagnostics, this section provides the following information:

- Objective of the diagnostic, including its data-gathering purpose and how it would contribute to reengineering mobilization

- Description of the diagnostic and how it was conducted

- Results of diagnostic

- How the diagnostic results were used to improve Phase I and to design Phases II and III.

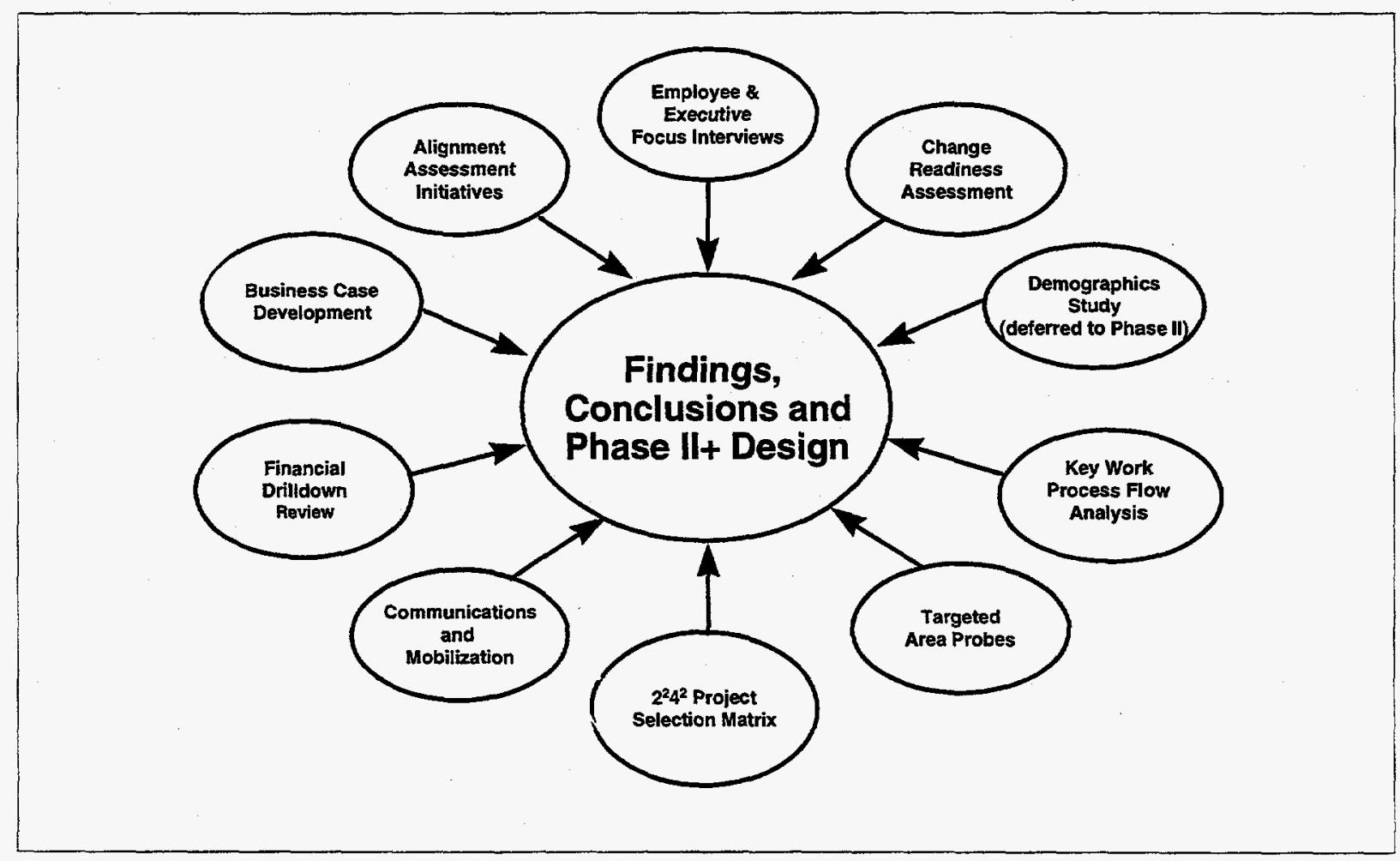

Figure 3-2. Phase I diagnostics. 


\subsubsection{Employee and Executive Focus Interviews}

The Phase I foundation was established by conducting focus interviews with 86 INEEL employees and executives (see Table 3-1). The purpose of the 1-11/2 hour interviews was to gain a consistent understanding of people's perceptions of change and to begin the reengineering mobilization process. To assure standardized data, each person was asked the same set of questions, worded in the same manner. The results of the focus interviews included introducing the Phase I compliance reengineering effort to employees, building teamwork, enabling the project team to assess the organization's position towards change, and identifying individuals' perceptions of organizational performance in key areas.

Table 3-1. Focus interview universe.*

\begin{tabular}{|c|c|c|c|}
\hline Focus Interviewees & DOE-ID & LMITCO & Total \\
\hline VP/Directors & & 9 & 9 \\
\hline Department Managers & & 38 & 38 \\
\hline Others & 11 & 38 & 49 \\
\hline Total & 11 & 75 & 86 \\
\hline
\end{tabular}

During the interviews, individuals were asked to rank in order each of 12 performance areas in terms of how great a barrier to change it is for the INEEL. They were also asked to estimate the potential cost savings and the need for change. To maximize free expression, the GDI project personnel conducted the interviews. The interview data was tabulated and evaluated; detailed interview results are provided in Appendix A of the Environmental Management Compliance Reengineering Project Phase I Report (INEL/INT-97-00108, January 1997). The interviews confirmed the initial planning assessment that potential cost savings are in excess of the $\$ 80$ million target and that there are significant barriers to implementing the changes necessary to achieve the savings. Five areas were identified as barriers to change by $50 \%$ or more of the individuals interviewed:

- Teamwork (65\%)

- Work processes and procedures (64\%)

- Communications (57\%)

- Leadership (52\%)

- Decision-making (51\%)

The encouraging findings were the universal agreement that change is needed and the widespread knowledge of the barriers that must be overcome to achieve that change.

The interview findings were used to target areas for further analysis during Phase I. Focus interviews also highlighted the critical need to develop reengineering solutions that addressed not only the technical requirements of the situation, but also the normal political and emotional responses to change. 


\subsubsection{Opportunity Selection}

The focus interviews helped narrow the field of potential opportunities for further consideration. The list of candidates was developed from the following sources:

- Idaho Chemical Processing Plant (ICPP) Effectiveness Improvement Initiative ideas

- Major issues from EM Requirements/Defensible Cost Project (direct murder boards)

- Submittals from INEEL personnel

- Results of the analysis (based on murder board information) conducted during the reengineering workshop held prior to Phase I

- Major issues from the Indirect Comprehensive Review Boards (indirect murder boards)

- Issues from FY 1996 company-wide procedure development task.

The project rankings developed from the focus interviews indicated that there was a high degree of agreement between the Compliance Reengineering Project Team and the EM directors (See Figure 3-3).

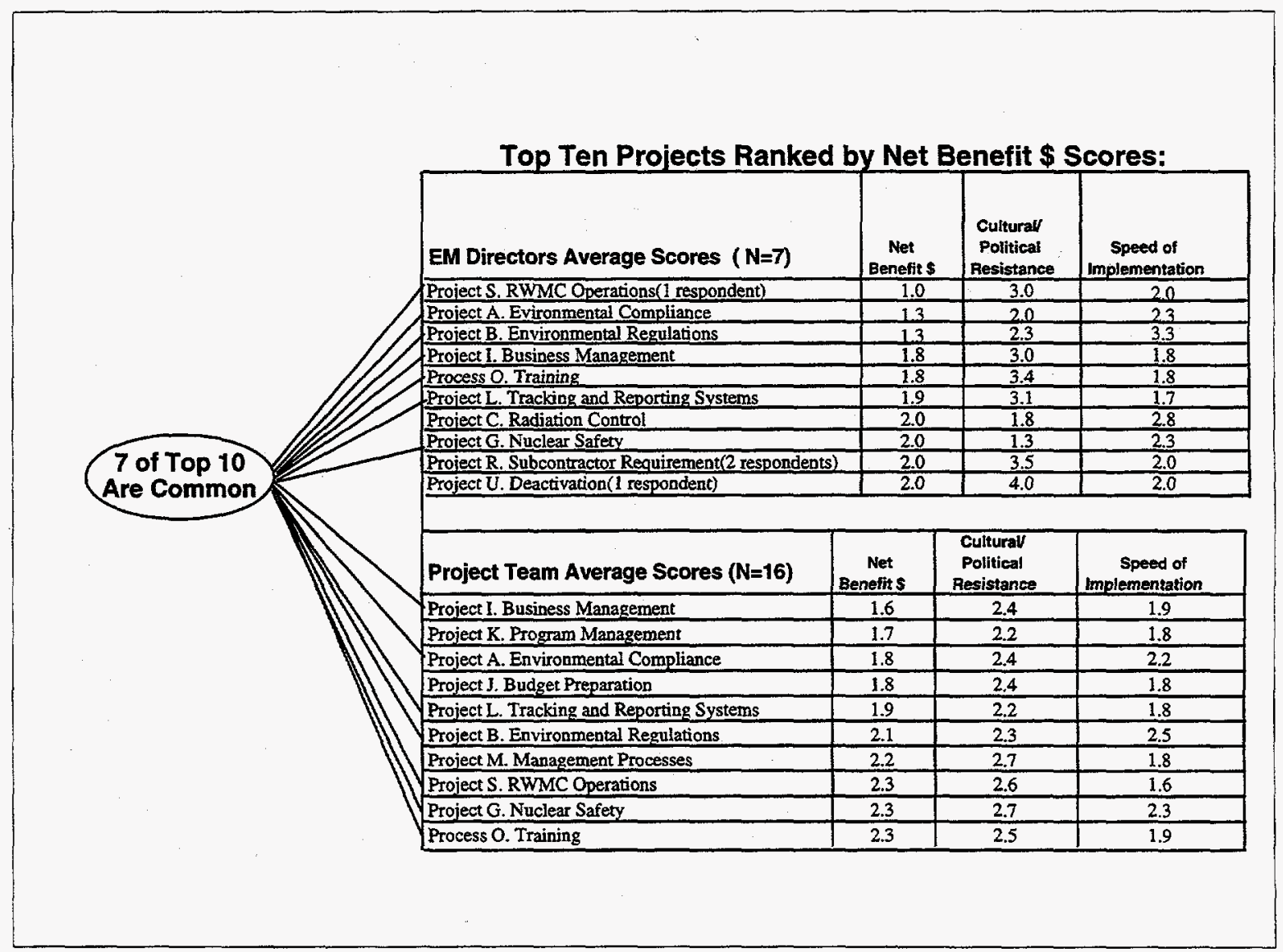

Figure 3-3. Focus interview rankings. 
The highest ranked projects were grouped into three logical categories and additional Phase I analysis was planned around those groupings. Each potential reengineering project was rated on its relative merit in three areas:

1) net benefit

2) cultural or political resistance

3) speed of implementation.

Teams were assigned to perform additional Phase I diagnostics. Each of the compliance reengineering teams was composed of members from DOE-ID, LMITCO, and GDI. The three areas and the key diagnostics to be used for each area are listed below:

- Site processes and procedures: operational, safety, and environmental opportunities (process flow analysis "brown papers")

- Modify a Resource Conservation Recovery Act (RCRA) permitted facility

- Facility closeout

- TRU waste operations

- Business management practices: budgeting, program management and tracking, and reporting opportunities (process flow analysis brown papers)

- Budgeting

- Project management, e.g. life cycle of a construction project

- Business case and organization assessment: financial analysis, benefits quantification, and assessment of people issues

- Change readiness assessment - focus groups

- Initiative assessment and alignment - interviews, assessment sample

- Financial analysis - financial "drill down."

\subsubsection{Process Flow Analyses or "Brown Papers"}

The process flow analysis (commonly called "brown paper") was a short, intense data-gathering and mobilization activity performed for each of the site and business management work processes. The purpose of the process flow analysis was to describe the process as it was being implemented and to generate comments regarding the effectiveness of each process. The brown-paper diagnostic provides a low-tech, high-touch approach to describing the process, its strengths, and the potential reengineering opportunities.

Small project teams did the initial diagraming of the process flows. Process refinement, employee mobilization, and building of ownership occurred during the widespread "brown paper reviews" or "fairs." More than 187 people participated in refining the brown papers for the five selected processes. The participants identified more than 154 improvement opportunities. The diversity of the employees included in refining the process flows is indicated by the broad range of facilities where brown paper reviews were conducted: Technical Support Annex (TSA)/Technical Support Building (TSB), ICPP, DOE-ID, 
Woodruff Avenue Complex (WAC), Willow Creek Building (WCB), Engineering Research Office Building (EROB), Test Reactor Area (TRA), Radioactive Waste Management Complex (RWMC), and Central Facilities Area (CFA).

The brown paper diagnostic (illustrated in Figure 3-4) consists of diagraming the work process on wall-sized brown paper. Key process steps are represented by rectangular boxes, and decision points are depicted as diamonds. Once the basic flow of the process is diagramed by the small project team, the brown paper is displayed to a wide range of individuals involved with the work process. The process flow is annotated to capture the complexity of the process. Individuals add to the flow diagram specifying wait times, approval times, rework loops, paper generation points, etc. In addition, each reviewer is asked to post three types of notes: yellow notes indicate process strengths, pink notes indicate opportunities for improvement, and green notes offer suggestions for improvement. The teams used red flags to identify opportunities for improvement with a high level of buy-in from the individuals reviewing the brown papers.

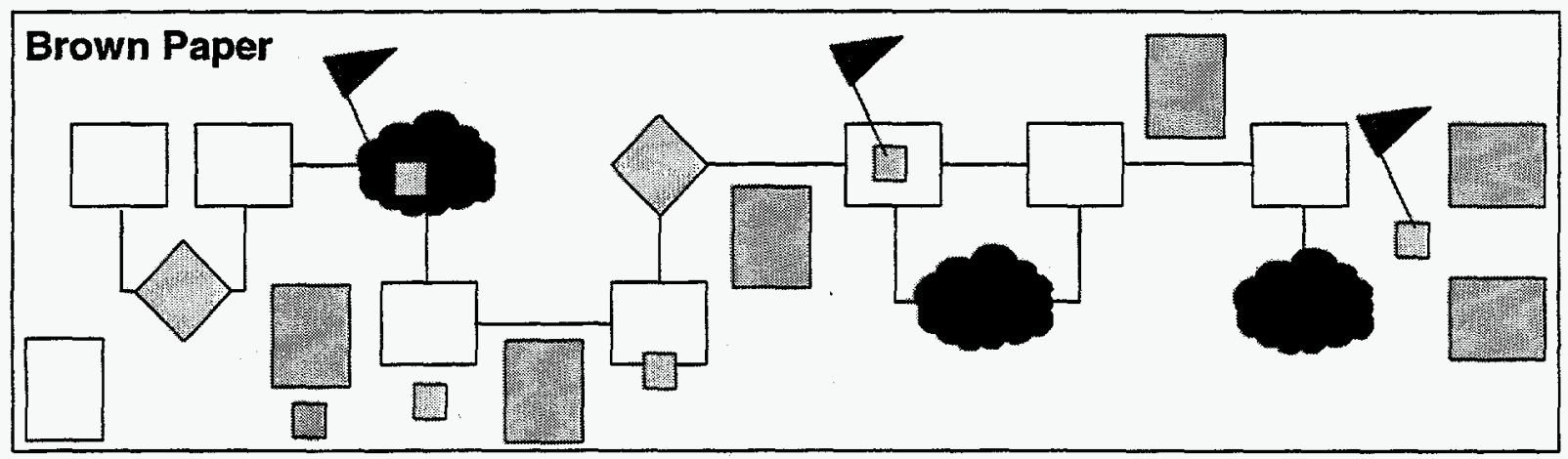

Figure 3-4. Brown paper illustrating the work process on wall-sized brown paper.

From each brown-paper analysis, the teams developed lists of the top improvement opportunities. The top opportunities were selected based on the degree of potential savings and the expected employee buy-in. Additional analyses documented assumptions and quantified the potential cost savings. This information was summarized on an opportunity chart for each reengineering option. The opportunity charts are included in the Compliance Reengineering working files. The top opportunities were presented to the Compliance Reengineering Steering Board. The steering board approved the selection of the high priority/high potential target areas for further analysis in Phase I.

\subsubsection{Targeted Area Probes}

Targeted area probes were a supplemental diagnostic aimed at providing relatively quick answers to help the teams focus on the best reengineering opportunities. Project team members developed a list of additional potential reengineering opportunities and related subjects that required targeted probes. The investigation techniques included conversations by phone, meetings with principal players, and research 
into the workings of particular processes. The results of the targeted area probes were used by the subteams doing the planned analyses.

During the early Phase I analysis (principally the brown-paper reviews), the project team, along with other employees, generated questions as well as ideas for potential reengineering opportunities. Project team members were asked to research questions and conduct analyses of new opportunities. For example, based on the questions raised regarding financial and budgeting processes, a GDI team member with an extensive background in finance and accounting investigated the INEEL's financial system, the organization of data, the integrity of the data, and the usefulness of financial information. The results of this financial investigation directly fed the budgeting team as well as the business case. The findings of the financial analysis are included in Appendix A of the Environmental Management Compliance Reengineering Project Phase I Report (INEL/INT-97-00108).

\subsubsection{Communications and Mobillization}

Multiple communication and mobilization activities were conducted to actively involve an increasing number of employees in the reengineering process. The objective was both to inform the employees and to gain their active support. Over the 8-week period for Phase I, communication and mobilization were achieved through three types of activities:

- Direct involvement (interviews, brown papers, focus groups)

- Communication progress updates (e-mail notes)

- Leadership engagement (Compliance Reengineering Steering Board meetings, workshops, and decision making meetings).

The communication and mobilization activities and the corresponding results are described in the relevant subsections. Focus interviews and brown papers are described in previous subsections, focus groups are described in the change readiness assessment subsection, and communication with the Compliance Reengineering Steering Board is described throughout this section. Communication and mobilization continued in Phases II and III. The nature of the design and implementation activities involved increasing numbers of LMTTCO and DOE-ID personnel.

\subsubsection{Change Readiness Assessment}

The purpose of the change readiness assessment was to identify characteristic behaviors at the INEEL in order for the project team to identify gaps in the capability to change and determine the actions required to address the gaps. To evaluate change readiness, the team conducted eight focus group sessions of $1-2$ hours each. The sessions were led by an experienced facilitator and included 111 people representative of different levels, jobs, and organizations. Over a 3-day period, change readiness sessions were held in the RWMC, Waste Reduction Operations Complex (WROC), ICPP, EROB, WAC, WCB, and DOE. (See Table 3-2 for a breakdown of the participants.) 
Table 3-2. Change readiness session participation (111).

\begin{tabular}{lccc}
\hline Participants: & DOE-ID & LMITCO & Total \\
\hline Management & $5 \%$ & $12 \%$ & $17 \%$ \\
Non-Management & $12 \%$ & $71 \%$ & $83 \%$ \\
Total & $17 \%$ & $83 \%$ & $100 \%$ \\
& & & \\
\hline
\end{tabular}

During the change readiness assessment sessions, the team obtained structured feedback on the significant enablers to change and unstructured feedback on the ways to improve change efforts. The assessment approach was based on GDI's experience with organizations that have successfully implemented major change. There are ten enabling change factors, grouped into four major areas:

Leadership

- Commitment of top leaders

- Vision and strategy

Resource Capability

- Critical mass of support and willingness to provide resources

- Commitment to staff development

- Management capability to change

Mind Set

- Shared feeling that change is necessary

- Long-term perspective

- Recognition of resistance to change

- Risk-taking

Flow of Information

- Commitment to free flow of information.

The change readiness assessment responses were captured on a five-point rating scale (from $1=$ "not characteristic, never happens here" to $5=$ "extremely characteristic, happens here all the time, without exception"). In GDI's experience, usually two of the ten categories are within the zone of acceptability, scoring between 3 and 4, and one category scores below 2 or 3 and stands out as a clear priority item. Flow of information typically has the lowest score.

Based on the broad sample of opinion regarding the ability and willingness to implement significant change at the INEEL, the project team learned that nine of ten key enablers for change were below the zone of acceptability and that seventy-two percent of the people felt that change is necessary. The individual scores for the ten enabling factors and aggregate scores for the four major areas are shown in Table 3-3. 
Table 3-3. INEEL Change readiness enabling scores

\begin{tabular}{|c|c|c|c|c|c|c|c|}
\hline 2.2 & Leadership & 2.5 & Resource Capability & 2.5 & Mind Set & 2.2 & $\begin{array}{l}\text { Flow of } \\
\text { Information }\end{array}$ \\
\hline $\begin{array}{l}2.2 \\
2.1\end{array}$ & $\begin{array}{l}\text { Commitment } \\
\text { of top leaders } \\
\text { Vision and } \\
\text { strategy }\end{array}$ & $\begin{array}{l}2.4 \\
2.4\end{array}$ & $\begin{array}{l}\text { Critical mass of support } \\
\text { and willingness to } \\
\text { provide resources } \\
\text { Commitment to staff } \\
\text { development } \\
\text { Management capability } \\
\text { to change }\end{array}$ & $\begin{array}{l}3.1 \\
2.6 \\
2.8 \\
2.2\end{array}$ & $\begin{array}{l}\text { Shared feeling that } \\
\text { change is necessary } \\
\text { Long-term } \\
\text { perspective } \\
\text { Recognition of } \\
\text { resistance to change } \\
\text { Risk-taking }\end{array}$ & 2.2 & $\begin{array}{l}\text { Commitment to free } \\
\text { flow of information }\end{array}$ \\
\hline
\end{tabular}

The scores for the key enablers highlighted specific emotional, political, and rational obstacles to implementing change. Based on the shared belief that change was needed and the low rating of the enablers for change, the project team identified the criticality of taking actions to address the areas of weakness. These specific actions becarne a part of Phases II and III. The drive toward successful change is portrayed in Figure 3-5.

- What is the vision?

- Is DOE committed to the vision?

- What does the vision mean to me and my facility?

- How do the strategy and vision fit together?

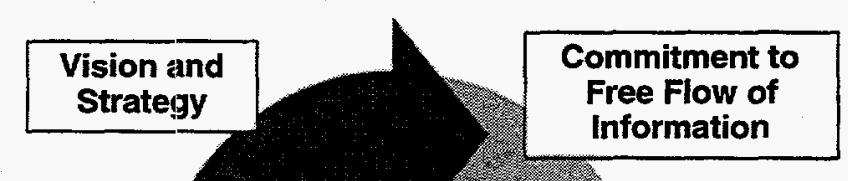

- Will the change process seek feedback from lower levels in the organization?

- What will be in place to quickly deal with the rumor mill?

Commitment of Leadership
Action /

Risk-Taking

$$
\begin{aligned}
& \text { - Are leaders working for } \\
& \text { the future of INEEL or } \\
& \text { parent companies? } \\
& \text { - Why can't we implement } \\
& \text { our recommendations? }
\end{aligned}
$$

- If things don't work out, will I be blamed?

- What's in it for me for taking a risk?

- Will I lose my job?

Figure 3-5. Addressing key questions to drive the INEEL forward to successful change. 


\subsubsection{Financial Drill-Down}

The purpose of the financial "drill-down" was to support business case quantification and help identify the additional areas with high potential for cost savings. The drill-down focused on the INEEL's FY 1995, 1996, and 1997 financial information and involved the following activities:

- Working with key financial and report creation resources to understand the composition and build-up of the operating cost elements

- Reviewing the actual-to-budget performances for key cost elements

- Gaining an understanding of the linkages from fund sources to cost elements, and from cost elements to financial statement reporting

- Drilling-down into a few key cost components

- Identifying additional potential opportunities for cost and budget management improvement.

By "peeling the onion" of accounting information and data, the financial drill-down enabled the team to gain a thorough understanding of the INEEL's financial system and performance. The drill-down provided the team with a financial perspective that was used when conducting process reengineering and other operations improvement diagnostics. The detailed findings from the financial drill-down are included in Appendix A of the Environmental Management Compliance Reengineering Project Phase I Report (INEL/INT-97-00108, January 1997). There were five key findings from the financial drill-down:

- The sheer magnitude of cost-element tracking contributed to unnecessary financial and operating management complexity. "Is the INEEL counting pennies to manage millions?"

- Financial operating numbers were continually "sliced and diced" in innumerable ways. This slicing and dicing consumed considerable time, required detailed system knowledge, and did not substantially increase the ability to truly manage costs.

- While expenditures generally trended with budgets, significant annual actual-to-budget dollar variations occurred in most accounts in FY 1995 and 1996, and continued into FY 1997.

- Annual budgets were a "moving target," since they were often rerun monthly.

- There was an opportunity to save significant money by improving the control over overtime costs, subcontractor costs, and year-end purchase of non-construction materials and supplies.

\subsubsection{Initiatives Assessment and Alignment}

The purpose of the initiatives assessment and alignment was to identify the INEEL's significant improvement initiatives and understand their impact relative to compliance reengineering. The intent was to accomplish the following results:

- Identify similar efforts and avoid duplication of work.

- Group similar efforts to achieve synergies.

- Prioritize the objectives of all change efforts so that resources are committed appropriately. 
Since there was no comprehensive inventory of existing initiatives, the team conducted an inventory. An initiative was defined as a significant improvement effort that meets the following specific criteria:

- Required a cross-functional tearn to study, redesign, and implement

- Required the involvement of various levels of the organization to accomplish

- Was considered significant by management of the relevant department, branch, organization, or facility

- Was not considered part of the normal job or responsibility of a department, branch, organization, or facility

- Had a well-defined duration or deliverable.

To develop the initiatives inventory, the team used existing information (murder boards, quality steering teams, etc.), interviewed personnel with a broad knowledge of improvement activities, crossreferenced the EM major issues list, and gathered project team input. To evaluate implementation of the existing initiatives, the team selected a sample of initiatives and then interviewed at least one knowledgeable person for each of the initiatives in the sample. While the focus of the initiatives process was the inventory and assessment, this diagnostic was another opportunity to communicate the purposes of reengineering and to increase the level of employee mobilization.

Attempting a large number of improvement initiatives reduces the likelihood of success for all of them and interferes with needed coordination, integration, and efficient use of resources. The analysis identified specific problems:

- There were more than 50 initiatives, many unbudgeted, with more initiatives to be approved.

- The INEEL did not have a systematic approach to approving and managing its initiatives.

- Not using a rigorous process to evaluate potential initiatives created specific problems:

- Possible misalignment of the initiative efforts with the overall direction of the company (only 5 of 15 responses indicatid a "strong alignment with INEEL success")

- Potential overlap of individual initiatives with existing efforts ( 8 of 15 responses indicated a "small or no effort to coordinate with other similar efforts")

- Lack of widespread knowledge or consensus on the specific benefits and goals to be achieved (7 of 15 responses indicated a "small or no effort to quantify and clearly state measurable results from the outset").

- Without clear, widely understood goals, progress and success were hard to measure or not measured ( 9 of 15 respondents indicated "little or no" ability to know if results have been met and implemented).

The existing initiatives were considered in the opportunity selection and planning for Phase II of the compliance reengineering effort. The additional tasks of addressing the existence of multiple initiatives and the corresponding issues of resource diversion and need for systematic initiatives' management were: deferred to Phase II. The inventory of initiatives is provided in Appendix A of the Environmental Management Compliance Reengineering Project Phase I Report (INEL/INT-97-00108, January 1997). 


\subsubsection{Business Case}

The objective of this activity was to develop an irrefutable business case that contained both the quantitative and qualitative assessment of the value that would be generated as a result of the reengineering implementation effort. The business case approach (graphically shown in Figure 3-6) synthesized the work done in the other reengineering diagnostics. Like the other diagnostics, it was both an analytical tool and part of the communications and mobilization strategy so critical to reengineering.

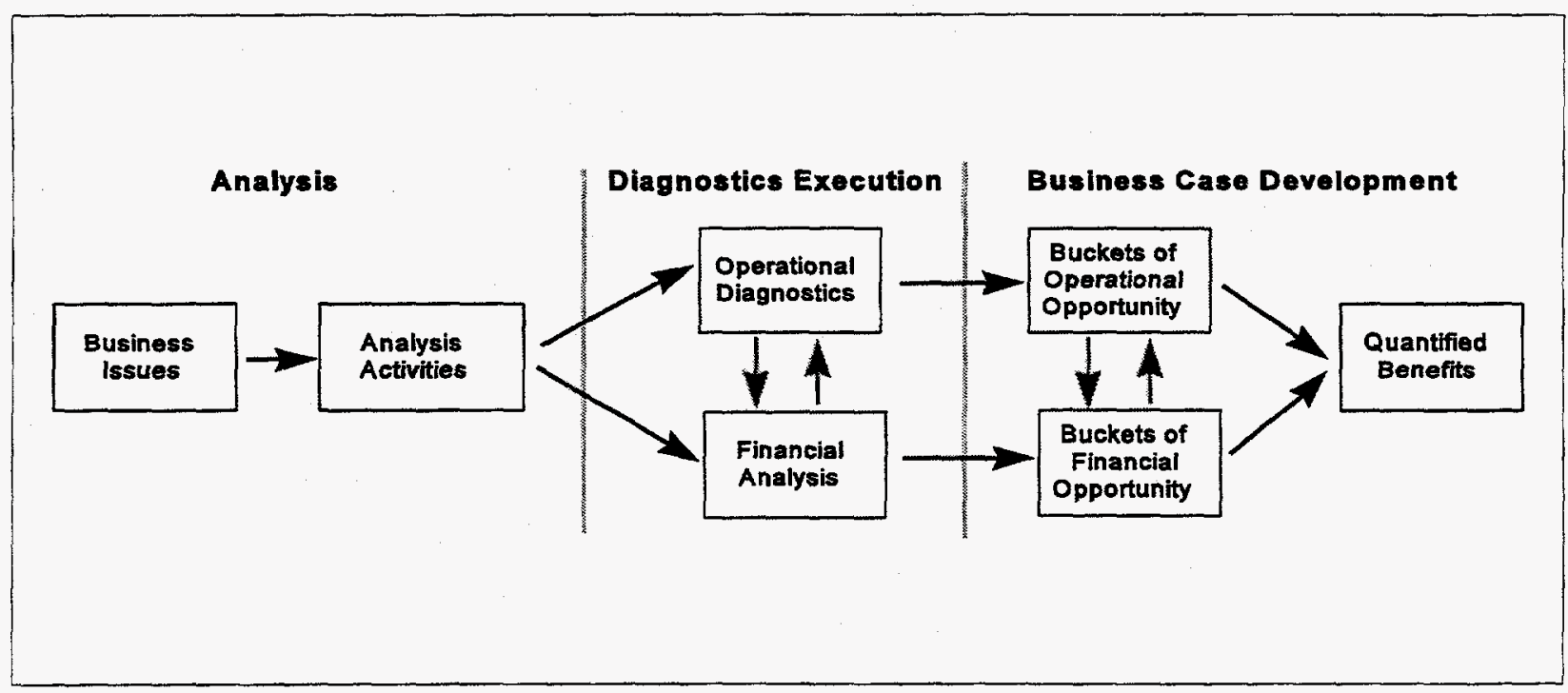

Figure 3-6. Business case approach.

The business case identified the financial drivers in the areas of opportunity for improvement, with the following results:

- Captured and integrated all improvement opportunities identified by Phase I diagnostics.

- Calculated and quantified the targeted impacts of improvement objectives by area.

- Assessed the impact on performance indicators, where possible.

- Determined the linkages across functions.

- Developed the opportunity charts clearly linking target benefits to target improvements.

\subsubsection{Project Selection Using the $2^{2} 4^{2}$ Process Reengineering Decision Matrix ${ }^{\mathrm{sm}}$}

The purpose of the $2^{2} 4^{2}$ matrix, a diagnostic tool developed by GDI, was to determine the organizations' opinions regarding proposed reengineering projects and to identify the projects with the highest value and chance of success. There are four dimensions of the matrix (illustrated in Figure 3-7), grouped into two categories:

\section{Behavioral elements:}

- Personal willingness to support and participate in change

- Perceived potential to achieve successful implementation 


\section{Financial elements:}

- Perceived costs to implement the change

- Perceived magnitude of the financial benefits.

The Compliance Reengineering Steering Board members and senior advisors were asked to rate each potential opportunity based on the descriptions and cost-benefit estimates. The LMITCO and DOE-ID voters rated the opportunities on the four elements. The responses, which were plotted on a $2 \times 2$ matrix, represented the level of economic and behavioral buy-in that existed. The combined scores for each opportunity formed the basis for the projects recommended for Phases II and III.

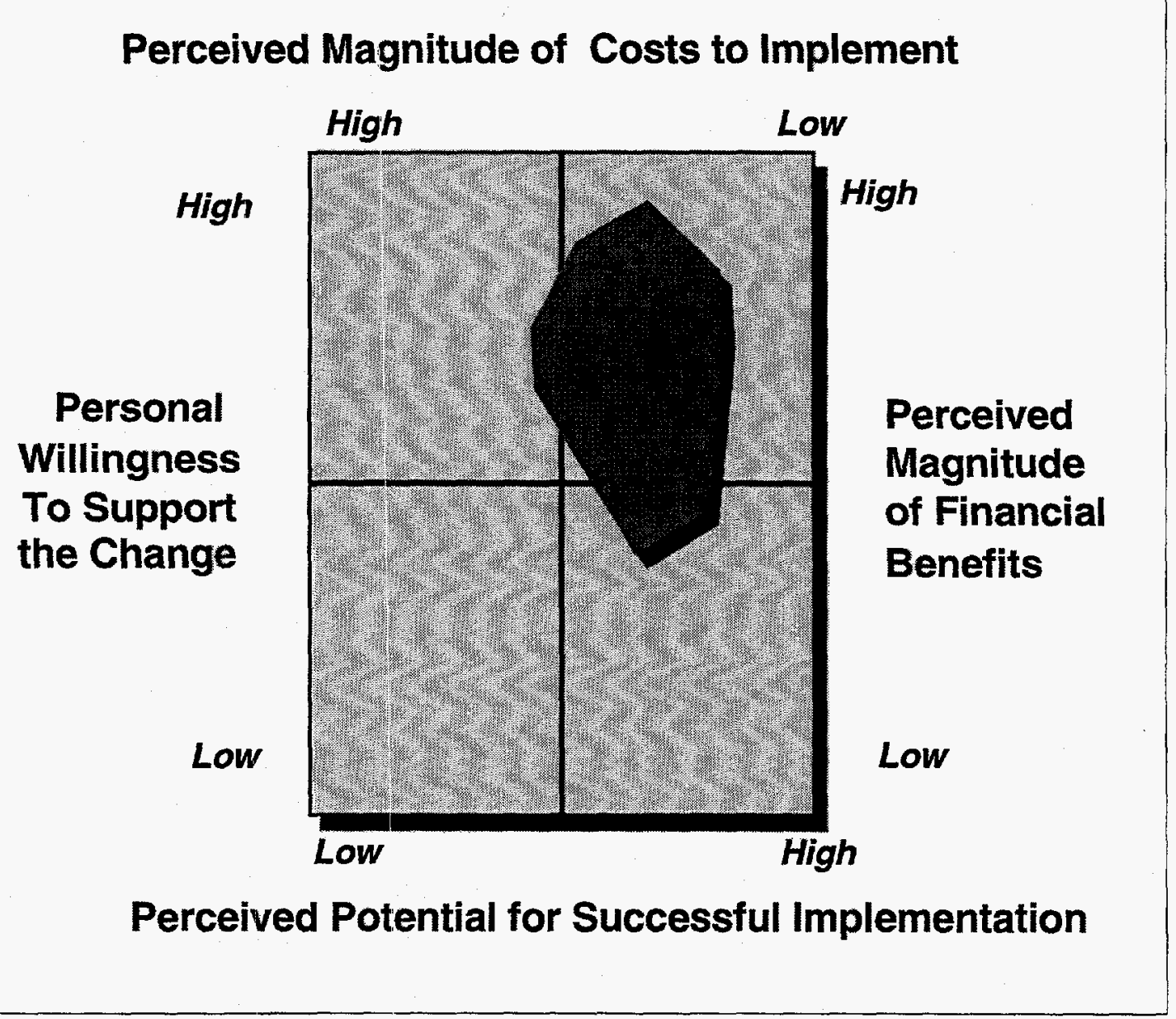

Figure 3-7. $2^{2} 4^{2}$ matrix: projects with highest chance of success and value. 


\section{Generalized Interpretations of The $2^{2} 4^{2}$ Graphs}

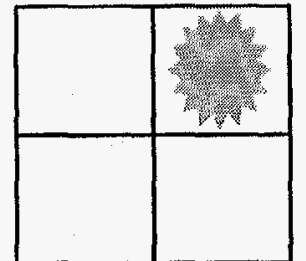

Quadrant 3

Just Do ItI

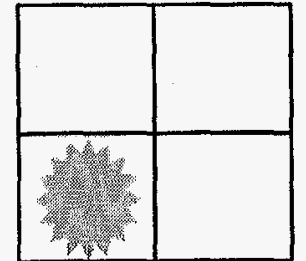

Quadrant 1 Run Like the Wind!

Certain Failure

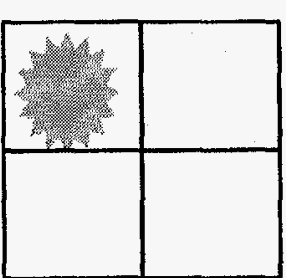

Quadrant 2

High on willingness, low on organizationa trust, high on cost, high on benefits

Risky

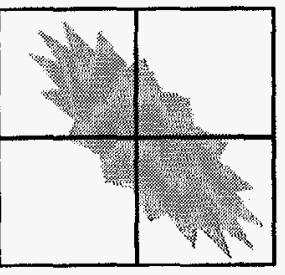

Bipolar Distribution

No consensus on willingness, no

consensus on

organizational trust, no consensus on benefits, no consensus on costs

Probable Failure

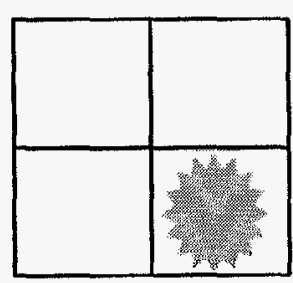

Quadrant 4

Low on willingness, high on organizational

trust, low on benefits. low on cost

Ho Hum!

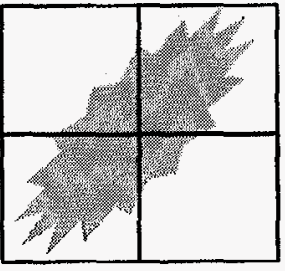

Bipolar Distribution

No consensus on willingness, no

consensus on organizational trust, no consensus on benefits, no consensus on costs

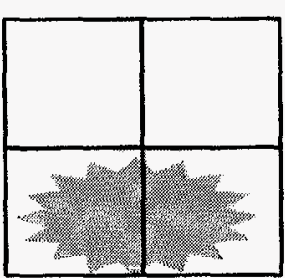

Bipolar Distribution

Low on willingness, no consensus on

organizational trust, low on benefits, no consensus on costs

Risky

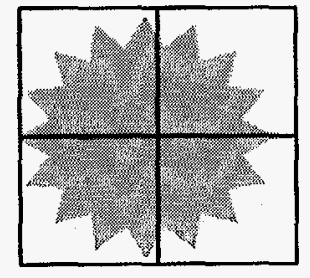

No Correlation

Probably Didn't Understand Project

Certain Failure

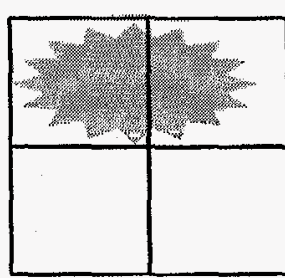

Bipolar Distribution

High on willingness, no consensus on organizational trust, high on benefits, no consensus on costs

Risky

$$
\text { high on cost }
$$

low on costs

Inconclusive

Probable Failure

Figure 3-8. Interpretations of the $2^{2} 4^{2}$ matrix. 


\subsection{Phase I Selected Improvement Projects for FY 1997}

The key results of compliance reengineering are both financial and nonfinancial, quantifiable and nonquantifiable. The basis for project selection and the key groundwork for proceeding into Phases II and III was the business case. The business case is the compilation of the cost benefit analyses and diagnostic findings. At the opportunity level, the business case is documented in the project theme descriptors and opportunity charts.

Successful reengineering requires much more than just detailed planning and rational business cases. Many worthwhile planned changes begin with best intentions, but never reach their destinations because the leaders of change fail to take into account all the aspects of change. To successfully implement real and lasting change, the INEEL addressed the technical, cultural, and organizational obstacles to change during Phase I, and continued to follow this approach in Phases II and III.

The projects evaluated during compliance reengineering all provide substantial economic benefit. The 19 projects, grouped into five work streams, selected by the Compliance Reengineering Steering Board met the critical decision-making hurdle: the projects had behavioral buy-in from $60 \%$ or more of the LMITCO and DOE-ID people who voted. While leaders rated projects on the various dimensions, the key to making change actually happen is selecting projects that have the support of $60 \%$ or more of the decision-makers.

The Phase I tasks generated the findings and conclusions that are the basis of the path forward. With corporate support and the Compliance Reengineering Steering Board's selection of the improvement projects for Phases II and III, the INEEL was ready to proceed into detailed design and implementation. The Phase II projects are shaded in Table 4.

Table 3-4. FY 1997 compliance reengineering potential and selected projects.

(Potential reengineering projects are listed below. The projects selected for Phases II and III are shaded.)

\section{Safety and Health}

1. Operational Requirements Manual Elimination-New Waste Calcining Facility (NWCF)MCPP

2. Safety Analysis Reports (SARs)

3. Occurrence Reporting

4. Radiation Control-Overcompliance

5. Radiation Control-Respirators

6. Site-wide Safety and Health

7. Safety and Health Support

\section{Environmental}

8. Environmental Restoration-Streamlining Document Review and Ad Hoc Requests

9. Environmental Support-Staff Reduction 
Table 3-4. (continued).

(Potential reengineering projects are listed below. The projects selected for Phases II and III are shaded.)

10. Permiting-RCRA Part B-eliminate unnecessary detail/training

\section{Operations}

11. Training-Trainee time and Training staffing levels

12. Maintenance

13. Quality

14. Configuration Management

15. Engineering Support

16. Work Processes

17. Craft Productivity: Schedule and Control, and Operations

\section{Project Management}

18. Shorten Project Time Frane

19. Consolidate Project Management Roles and Responsibilities

a. Facility Decontamination, Decommissioning and Demolition

b. Construction

c. Cost Estimating

20. LMTCOParsons-Eliminate organizational redundancies

21. Subcontractor Project Maragement Sy stems

\section{Budgeting and Performance Measures}

22. Budgeting

23. Data and Information

24. Performance Measures

\section{Other Reengineering Opportunities}

25. Improve Management of Overtime Costs

26. Improve Management of Subcontractors Costs

27. Improve Management of Year-End Non-Construction Materials and Supplies Expenditure Spikes

A summary of the expected cost and benefit of each project and its relative ranking is shown in Appendix A. 


\title{
3.3 Phase II Organization
}

\subsubsection{Streams and Teams}

The Phase II projects were organized into five broad categories called streams:

\author{
I. Safety \\ II. Environmental \\ III. Operations \\ IV. Facility Construction and Closeout \\ V. Business/Project Management.
}

The five major streams were organized into an integrated project, displayed as a structure in Figure 3-9. As the figure illustrates, the structure is based on the premise that the INEEL can be run like a business, with effective integrated management. The stream leads provided guidance to the reengineering team members, who prepared the detailed project designs during Phase II. Reengineering teams were composed of members from various functions, departments, facilities, levels (management, non-management, bargaining), and subcontractors (Parsons, Coleman). This broad participation helped ensure successful implementation. The sponsors, leaders, and team members are listed in the acknowledgments section. Since the organization and process described in this section are continuing throughout the entire project, all descriptions are given in the present tense.

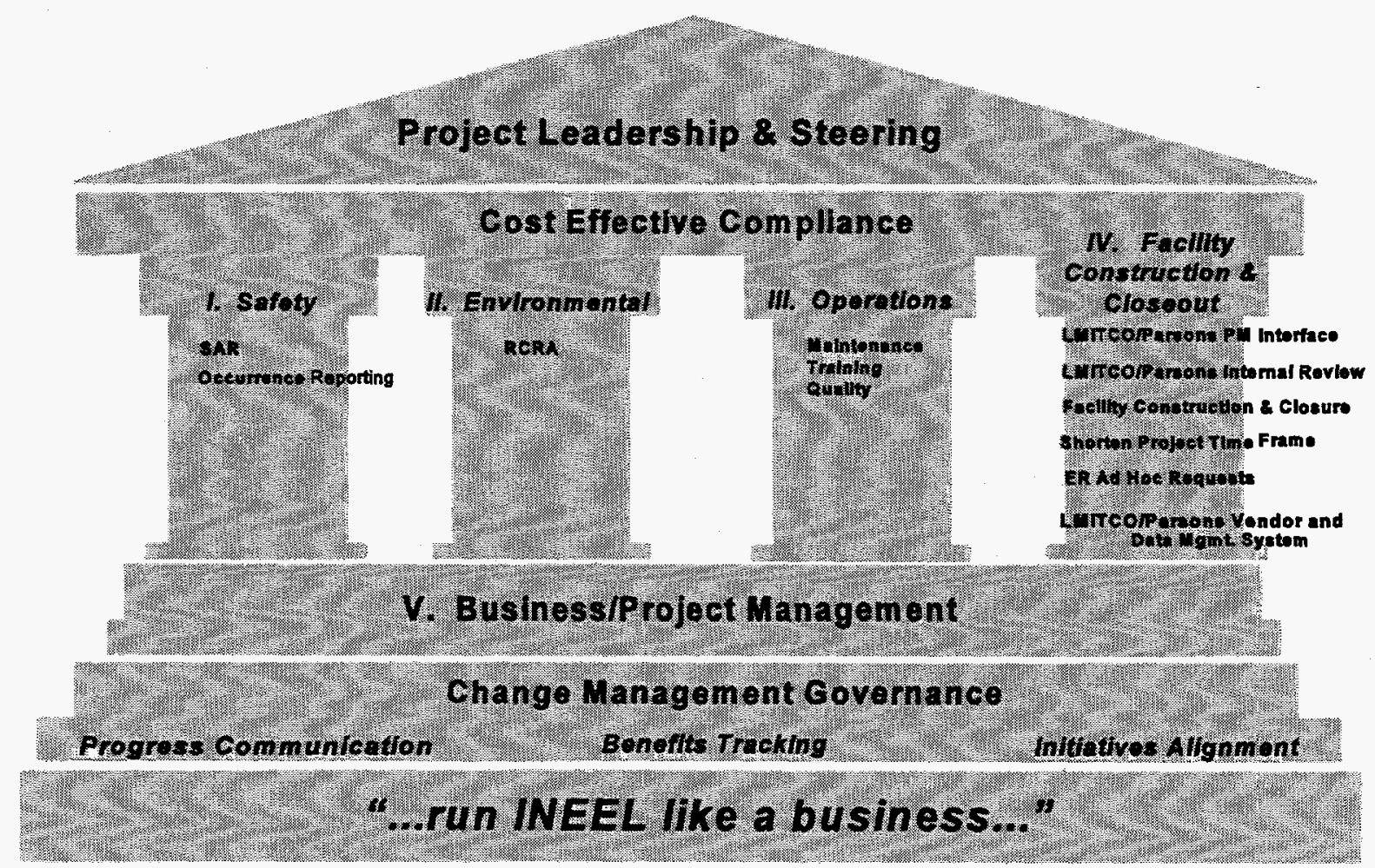

Figure 3-9. Structured framework of Compliance Reengineering. 


\subsubsection{Champions and Advocates}

Each of the five streams had a LMITCO executive champion and a DOE-ID advocate, a joint participation that helped ensure successful implementation of the reengineered projects. The executive champions and advocates have the following specific roles and responsibilities:

- Make stream-specific recommendation approval decisions

- Provide relevant content expertise

- Ensure alignment with the strategic plan and goals

- Ensure that validation and integration addresses cross-director issues

- Ensure adequate work stream resources

- Provide advice and coaching to team members

- Act as advocate and liaison for teams to the steering board

- Ensure thoroughness of inquiry by work teams

- Regularly monitor team progress and milestone attainment.

\subsubsection{Project Leadership and Steering}

Project leadership and steering, which caps the structure in Figure 3-9, provides overall project leadership and guidance. This function is provided by the Compliance Reengineering Steering Board and senior management advisors (identified in the acknowledgments section). The steering board has the following roles and responsibilities:

- Planning

- Assist team leaders in selecting team members; make resources available

- Review and approve all project work plans and theme descriptors.

- Developing teamwork

- Encourage and participate in team-building activities

- Role-model customer-supplier collaboration and partnering

- Champion accomplishment and progress of the teams to peers and subordinates.

- Communicating

- Participate in formal communication events

- Communicate regularly with other executive members

- Assist in preparing and presenting communications to entire organization.

- Managing and leading

- Empower the teams; encourage "break-through thinking;" embrace change

- Focus on the good of the whole; no hidden or personal agendas

- Encourage the "airing" and resolution of all relevant issues

- Assist teams in overcoming barriers to implementation

- Act as a sounding board and contribute suggestions and advice to teams

- Review and approve recommendations for change

- Assist in planning and implementation of change. 


\subsubsection{Change Management Governance}

Change management governance, depicted as steps leading to the structure in Figure 3-9, provides: communication, mobilization, and integration, benefits tracking, and initiatives alignment.

\section{Communication/Mobilization/Integration}

A Communication/Mobilization/Integration team was formed to provide specific functions during the compliance reengineering effort:

- Provide information on compliance reengineering to personnel

- Communicate progress of reengineering

- Mobilize the work force

- Integrate initiatives and work teams

- Provide interaction and coordination between compliance reengineering and other organizations.

In an effort to demonstrate the alignment of the compliance reengineering implementation plans, as well as provide an initial look at aligning these plans with other NEEL-wide initiatives, the team developed a "Transforming the Future of the INEEL" map. This map, which is over 200 square feet, is used to communicate the reengineering changes to INEEL employees. It illustrates all three phases of the compliance reengineering process and the changes fundamental to achieving true business transformation at the INEEL. A presentation of the map and its implications can be scheduled by calling the Compliance Reengineering office at (208) 526-1348.

The team used a variety of communication and mobilization tools, including the following activities:

- Implementing a compliance reengineering hot line (526-2233)

- Distributing weekly highlights by intranet

- Publishing articles in Lockheed Martin Star

- Establishing Compliance Reengineering home page on intranet (http://home/compliance), which included a discussion stream and weekly team flash reports that facilitated cross-team communication and integration

- Providing status reports at manager/supervisor meetings and to the Compliance Reengineering Steering Board

- Presenting Compliance Reengineering Excellence Awards

- Preparing, presenting, and distributing presentations

- Integrating communications with Projectization, Enhanced Work Planning, Long-Range Plan, and Ten-Year Plan groups

- Presenting $\$ 80$ million power bars to all steering board members and project team members. 


\section{Projects Benefits Tracking}

The Projects Benefits Tracking Team implemented a compliance reengineering benefits tracking and reporting system. It will track projected benefit estimates by project and track savings achieved during FY 1998 through 2002. The reengineering project team leader will provide updated Phase III information monthly to the benefits tracking coordinator for incorporation into the benefits tracking database. The Compliance Reengineering Steering Board will review the benefits tracking reports on a regular basis.

\section{Initiatives Alignment}

The Initiatives Alignment Team provides overall integration and coordination of the compliance reengineering projects, related EM initiatives, and implementation planning. The team found numerous improvement teams and initiatives throughout the INEEL, including the following:

- Integrated product teams

- Enhanced work planning teams

- Quality steering teams

- Voluntary Protection Program

- Projectization

- Improvements within the Army Corps of Engineers report

- Improvements within the INEEL Long-Range Plan

- Integrated Safety Management System

- Self-assessment

- Environmental Management System

The Initiatives Alignment Team promoted coordination, integration, and efficient use of resources among the various improvement efforts. The initiatives alignment activities and recommendations are discussed in Section 3.5.2. 


\subsection{Phase II Process Redesign}

Phase II of the Compliance Reengineering Project began January 6, 1997, after the reengineering projects were selected during Phase I. The purpose of Phase II was to reengineer the selected projects to achieve the anticipated improvements and cost savings. As indicated in Figure 3-10, Phase II was a five-step process:

1. Team startup: organization of team members

2. Process visioning: identification of customer needs, design criteria, and performance indicators

3. As-is analysis: evaluation of the existing process

4. To-be design: detailed project design of the reengineered project

5. Implementation planning: outline of activities and schedule to achieve the reengineered process.

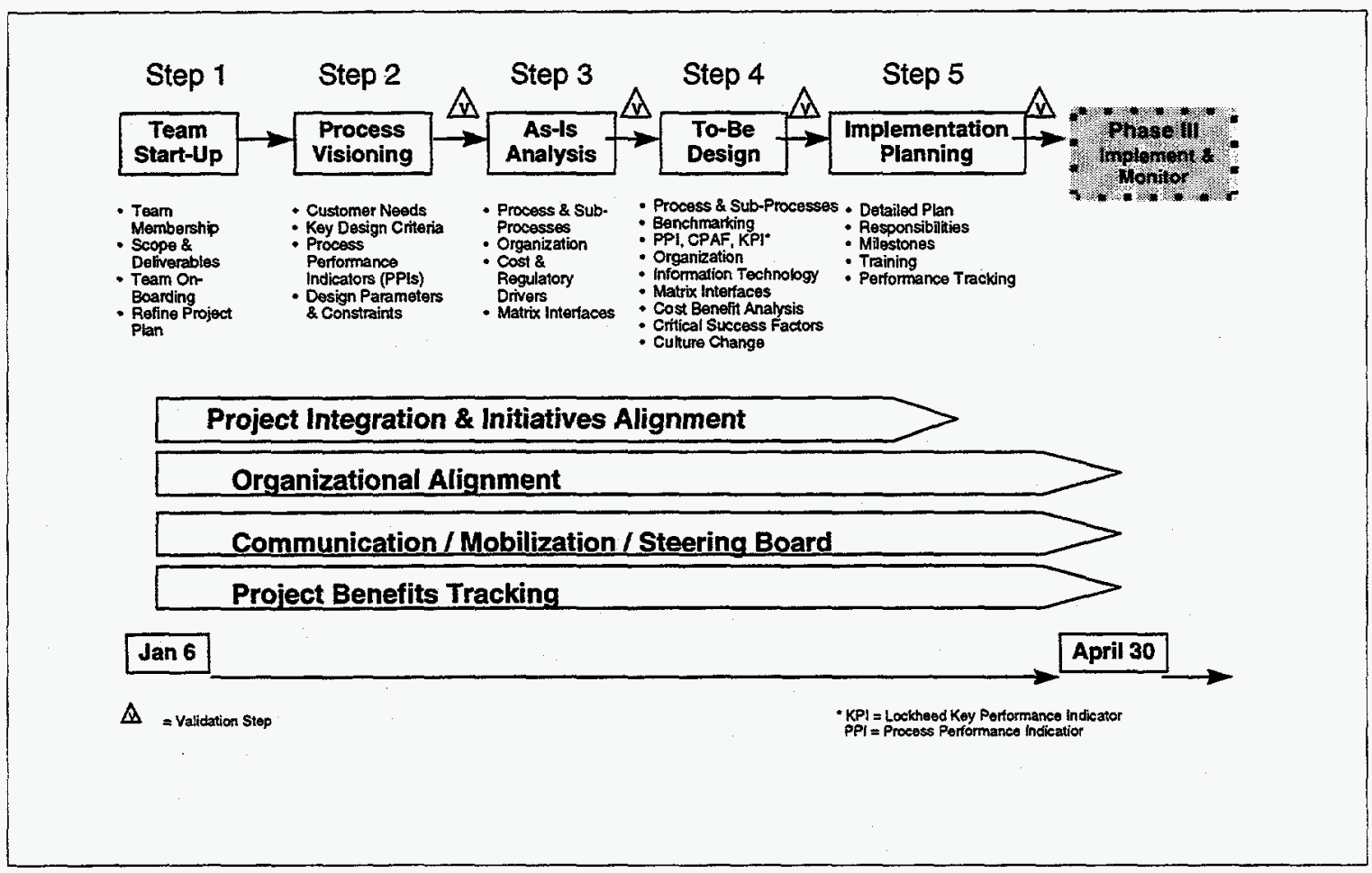

Figure 3-10. Compliance Reengineering Phase II process.

Process owners validated each step of the Phase II process. Project teams were provided with "war rooms," where they prepared and displayed detailed charts and documentation. Figure 3-11 illustrates the war room materials. Examples of the war room charts for the RCRA permit project are used as illustrations in this Phase II process description. More extensive war room materials from the maintenance project are included in Appendix $A$ of the Environmental Reengineering Compliance Reengineering Project Phase II Report (INEL/INT-97-00268, May 1997), and war room charts for other specific improvement projects are included in the project file. Phase II was completed on April 30, 1997; completion criteria required a detailed implementation plan for each specific reengineering project. The detailed project designs, implementation activities, and benefits and tracking information are provided in Section 4. 


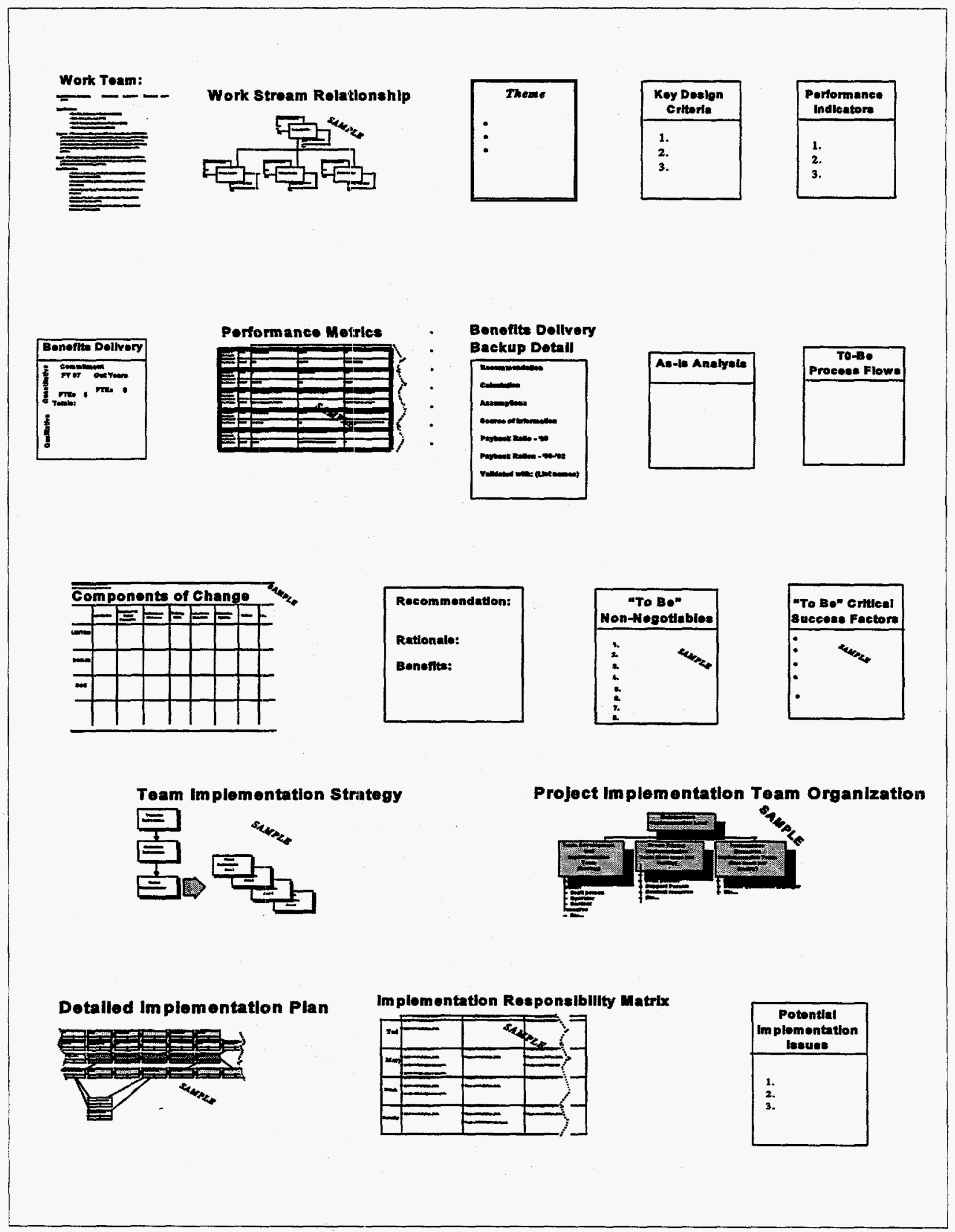

Figure 3-11. War room charts and documentation. 


\subsubsection{Team Startup}

During team startup, reengineering teams were organized for each of the specific reengineering projects. This step took much longer than anticipated due to the many other initiatives and activities competing for available resources. Once the teams were established, they defined the project scope and deliverables and refined the project plans. Figure 3-12 is an example of the RCRA team charter, which identifies the team's project purpose, scope, and deliverables.

WWEEGDH RCRA
Work Team: RCRA
Project Stream: Environmental Stream Lead: B. Angle TeamLead: B. Angle
Team Members:
Dennis Forsberg, RWMC Operations
Jim Jackson, NEPA and Permitting Dept.
Jay Mitchell, NEPA and Permitting Dept.
Paul Sloan, RWMC Operations
Purpose: The purpose of the team will be to review the interpretation and implementation of the
RCRA Part B Permit at the Radioactive Waste Management Complex (RWhC) to eliminate
Costly unnecessary details and activities not specifically required by the permit to meet 40
CFR 264 requirements. This process will identify for management where it is possible to
reduce unneeded monitoring, surveillance, record-keeping, training and maintenance
activities and recommend to management which opportunities to implement.
Scepe: RWMC, Environmental Affairs
Key Deliverables
Documentation of “As Is" condition with costs
Documentation of "To Be" condition with potential cost savings
Implementation Plan

Figure 3-12. Team charter with project members, purpose, scope, and deliverables.

\subsubsection{Process Visioning}

During process visioning, teams refined the overall view of their project from the conceptual ideas of Phase I. For example, Figure 3-13 is the RCRA vision statement. Teams evaluated customer needs, defined key design criteria, and designated initial key process performance indicators for measuring performance during implementation. They identified the project objectives and documented them on a work project theme chart (Figure 3-14). They also documented the quantitative and qualitative benefits on a project benefits chart. They defined project roles and responsibilities and prepared a stream responsibility matrix (Figure 3-15) to illustrate them. They illustrated how the stream and projects were organized on a compliance reengineering projects and work stream relationships chart (Figure 3-16). The teams identified related projects and coordinated and integrated with those related teams. They illustrated the related projects on a project integration chart (Figure 3-17). Some of the teams also prepared a project performance metrics chart, which they used to measure their performance during Phase II and III. 


\section{RCRA Part B Permit: Environmental Compliance Vision}

Outstanding Compliance means achieving excellence in performance while eliminating costly, non-value added, over compliance

This means:

- Meeting requirements

- Knowing where vulnerabilities are and fixing them

- Knowing compliance status and taking timely preventive and corrective action

- Consistent interpretation and application of requirements across the site

- Being recognized as excellent at compliance activities

- Low cost

- No violations

Figure 3-13. Process visioning.

INEELAOP-RCRA

\section{RCRA Part B Theme}

- Eliminate excessive costs of compliance with the RCRA Part B Permit through:

- Elimination of tasks in permit not required by RCRA

- Revision of interpretations that exceed RCRA requirements

- Reduced costs of perinit maintenance

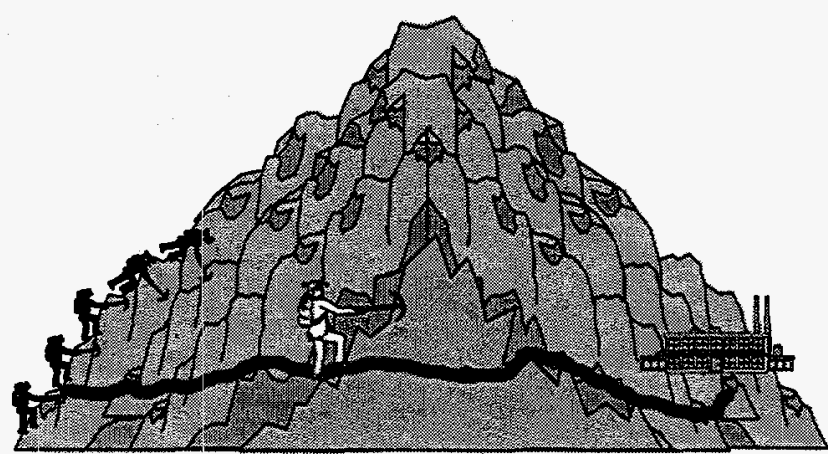

Figure 3-14. Project theme and objectives of the project. 


\section{RCRA Permit Stream Responsibility Matrix}

\begin{tabular}{|c|c|c|c|c|c|c|}
\hline & $3 / 24$ & $3 / 81$ & 46 & 4.13 & 470 & $4 \sqrt{27}$ \\
\hline $\begin{array}{l}\text { Bruce } \\
\text { Angle }\end{array}$ & $\begin{array}{l}\text { - Meot with DOE } \\
\text { Advocate, Waste } \\
\text { Ops Director } \\
\text { - Initlate permit } \\
\text { modtilieatlon } \\
\text { fundting review }\end{array}$ & $\begin{array}{l}\text { - Prepare and } \\
\text { present cca } \\
\text { request for permit } \\
\text { modificalton } \\
\text { funding }\end{array}$ & $\begin{array}{l}\text { - Follow up on } \\
\text { training program } \\
\text { - Prepare } \\
\text { Memorandum of } \\
\text { Understanding }\end{array}$ & $\begin{array}{l}\text { - Roview noed for } \\
\text { permit } \\
\text { modllication } \\
\text { - Follow up on } \\
\text { training changes }\end{array}$ & $\begin{array}{l}\text { - Determine bentits } \\
\text { from revised } \\
\text { tralaing }\end{array}$ & 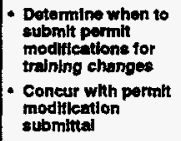 \\
\hline $\begin{array}{l}\text { Mike } \\
\text { Wolters }\end{array}$ & - Raviow tindinge & - Slgn CCB request & & $\begin{array}{l}\text { - Review } \\
\text { Memorandum of } \\
\text { Understanding }\end{array}$ & & $\begin{array}{l}\text { - Coneur wilth permith } \\
\text { modifleation } \\
\text { submitital }\end{array}$ \\
\hline $\begin{array}{l}\text { Craig } \\
\text { Kvamme }\end{array}$ & - Reviow flindinge & $\begin{array}{l}\text { - Concur on tralning } \\
\text { modittemtions } \\
\text { - Sign CCB request } \\
\text { - Sand botter to } \\
\text { supervicore } \\
\text { - Roviow } \\
\text { malintenance } \\
\text { program }\end{array}$ & - Dlecuses with & $\begin{array}{l}\text { - Roview } \\
\text { Memorndum of } \\
\text { Understanding }\end{array}$ & & $\begin{array}{l}\text { - Concur whin parmit } \\
\text { modificution } \\
\text { submitual }\end{array}$ \\
\hline $\begin{array}{l}\text { Dennis } \\
\text { Forsberg }\end{array}$ & $\begin{array}{l}\text { - Rovilew pormit } \\
\text { moditication } \\
\text { budgot }\end{array}$ & & $\begin{array}{l}\text { - Follow up on } \\
\text { tralining progeam }\end{array}$ & & & \\
\hline Wim & & 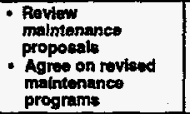 & 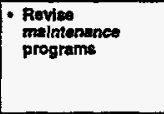 & 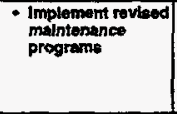 & & \\
\hline Jim & & $\begin{array}{l}\text { - Reviow with statio } \\
\text { DEa }\end{array}$ & $\begin{array}{l}\text { - Propare } \\
\text { Memorandum of } \\
\text { Understanding }\end{array}$ & $\begin{array}{l}\text { - Roview } \\
\text { Memorandum of } \\
\text { Underetanding }\end{array}$ & & $\begin{array}{l}\text { Doterming when to } \\
\text { submti permit } \\
\text { modillestlons for } \\
\text { training changes }\end{array}$ \\
\hline $\begin{array}{l}\text { Tom } \\
\text { Clements }\end{array}$ & - Roview findlings & $\begin{array}{l}\text { - Concur on training } \\
\text { modificaltons } \\
\text { - Send leter to } \\
\text { supervisors } \\
\text { - Sign CCB request } \\
\text { - Reviow maintenance } \\
\text { program }\end{array}$ & & $\begin{array}{l}\text { Review } \\
\text { Momorandum of } \\
\text { Underesending }\end{array}$ & & \\
\hline
\end{tabular}

Figure 3-15. Responsibility matrix — project and implementation roles.

\section{INEELVOH- RCRA \\ Compliance Reengineering Projects \& Work Stream Relationships \\ (Environmental)}

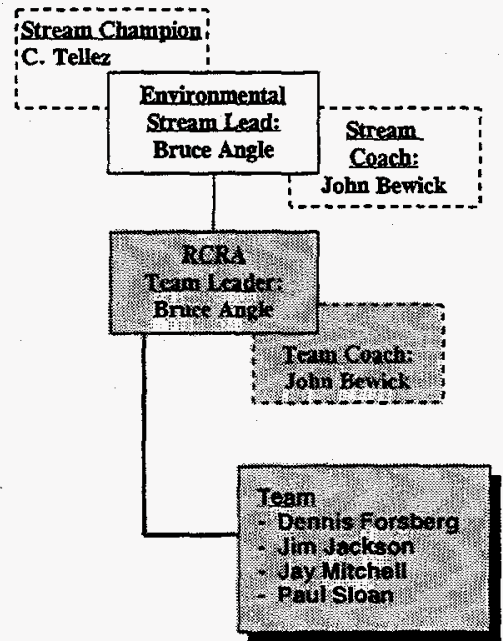

$5 / 13997$

Figure 3-16. Compliance reengineering projects and work stream relationships chart. 


\section{WEELGOH RGRA \\ Compliance Reengineering Phase II - Project Integration}

RCRA

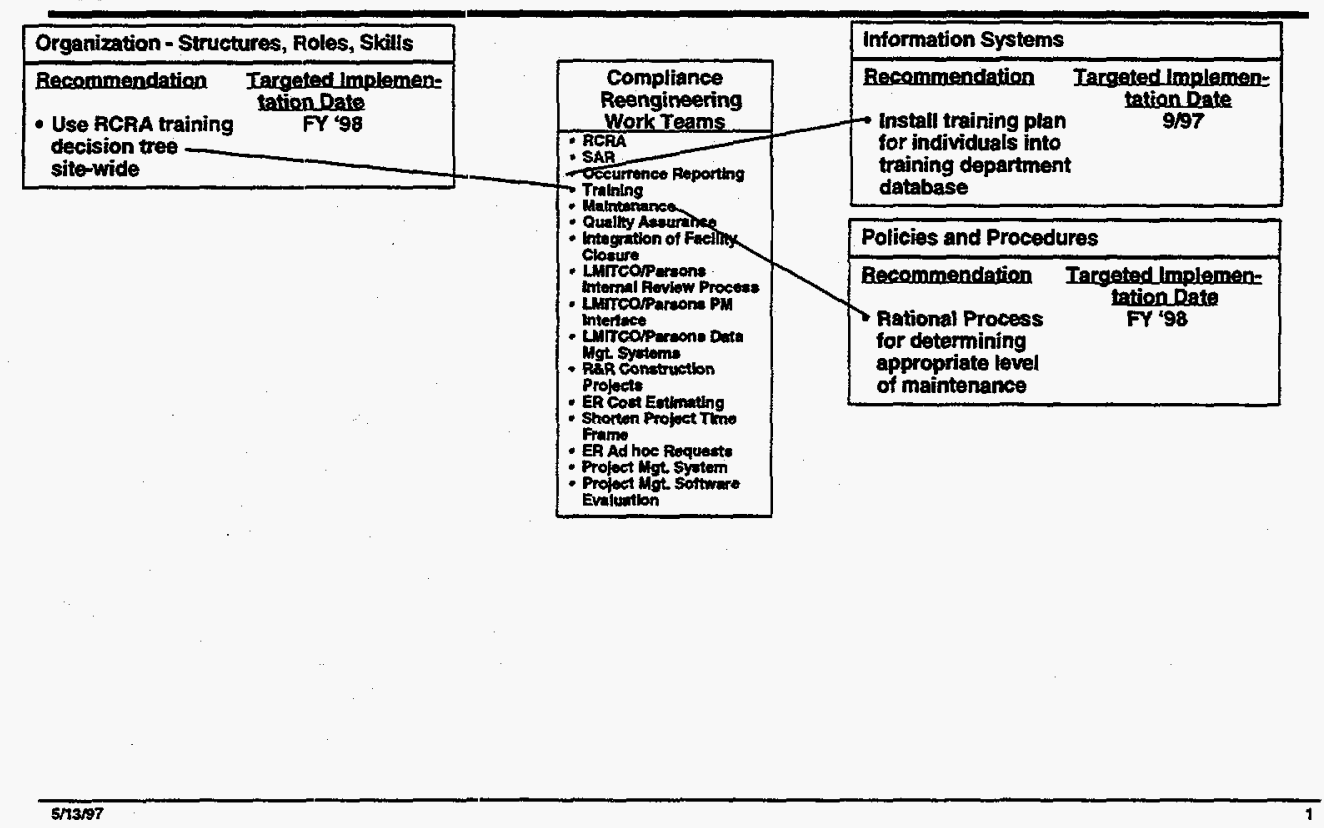

Figure 3-17. Project integration chart.

\subsubsection{As-ls Analysis}

Teams thoroughly documented the as-is analysis, and process owners validated it. During the as-is analysis, teams prepared numerous charts and tables, which they hung in their war room (Figure 3-11), where they further analyzed and revised them.

The brown-paper chart, a technique used in the Phase I analysis and illustrated in Figure 3-4, was one tool used to illustrate and analyze processes and subprocesses, roles, responsibilities, interfaces, dependencies, cycle times, information flow, and work product flow. Personnel used different colored post-it notes to provide comments on the brown paper regarding efficiencies, inefficiencies, cycle times, bottlenecks, and process flow.

Some of the teams performed organizational analysis to determine the baseline organizational profile, organizational resources, and quality of matrix interfaces and relationships. If needed, they prepared charts to document existing roles.

Process owners validated the teamis' as-is analyses. From these analyses, the teams identified and analyzed inefficiencies, cost drivers, and regulatory drivers. 


\subsubsection{To-Be Design}

Teams thoroughly documented the to-be design by preparing numerous charts and tables that reflected the planned changes and hung them in their war rooms. Process owners validated the teams' to-be designs.

Compliance reengineering teams determined the critical success factors and listed them in a chart (Figure 3-18). They determined the cultural change requirements. Where applicable, they identified the to-be non-negotiables and also documented them in a chart. They determined how to incorporate information technology. Some teams determined benchmarks to identify performance gaps which must be closed to achieve the desired results. Then, they identified the performance measures. If necessary, teams prepared a Project Performance Metrics chart (Figure 3-19) documenting how the to-be process would be measured during implementation. After the teams reengineered processes and subprocesses, they prepared to-be process flow diagrams to illustrate the reengineered process.

The teams conducted a cost-benefit analysis to ensure a five-to-one benefit-to-cost ratio. Then, they prepared a benefits delivery commitment (Figure 3-20) illustrating the quantitative and qualitative cost benefit of the to-be design, with a benefits delivery commitment detail (Figure 3-21) for each quantifiable recommendation.

Where applicable, teams identified the to-be organizational structure and identified the to-be matrix interfaces and prepared an organization chart depicting the new organization.

The teams identified what needed to change and documented it in a components of change chart (Figure 3-22 and the as-is/to-be components of change tables in Section 4). This chart illustrated the as-is process and the to-be process. The teams prepared DACI (doer, accountable, consult, inform) charts (Figure 3-23), and a Responsibility Matrix (Figure 3-15), which documented the to-be roles.

For recommendations requiring more detail than the components of change charts, teams prepared a work standards chart (Figure 3-24), which identified the team's recommendation, rationale, and benefits of the reengineered process.

The charts and documentation prepared during to-be design were used to plan the implementation. 


\section{Critical Success Factors}

- Correct interpretation of RCRA requirements

- Proper training of supervisors in designating individual employee training plans

- Successful revision of training database

- Acceptance of revised preventive maintenance schedules

- Annual review process tc ensure on-going correct implementation of program

- Management acceptance of reduced permit maintenance program

- Acceptance by State DEG, Unions

5/1398

Figure 3-18. Project critical success factors chart.

INEEMEOT-RCRA

\section{RCRA Performance Metrics}

\begin{tabular}{|c|c|c|c|c|}
\hline & & Apral-97 & Mav-97 & \\
\hline \multirow{2}{*}{$\begin{array}{l}\text { Metric } 1 \\
\text { Reduced } \\
\text { Training } \\
\text { Costs }\end{array}$} & Plan & $\begin{array}{l}\text { Respecify individual training } \\
\text { plans for } 210 \text { employees }\end{array}$ & $\begin{array}{l}\text { Submit revised training plan to State as } \\
\text { Class II permit modification }\end{array}$ & \\
\hline & Actual & & & \\
\hline \multirow{2}{*}{$\begin{array}{c}\text { Metric } 2 \\
\text { Revised PM's }\end{array}$} & Plan & $\begin{array}{l}\text { Revise specified I'M's } \\
\text { Notify supervisori. employees }\end{array}$ & & \\
\hline & Acrual & & & \\
\hline \multirow{2}{*}{$\begin{array}{l}\text { Metric 3 } \\
\text { CCB Change } \\
\text { in Permit } \\
\text { Maintenance }\end{array}$} & $P t a n$ & $\begin{array}{l}\text { CCB Change of } \$ 70,000 \text { in } 1997 \\
\text { budget }\end{array}$ & $\begin{array}{l}\text { Memorandum of Understanding } \\
\text { between Waste Operations and } \\
\text { Environmental Affairs for FY } \\
\text { '98-02 }\end{array}$ & \\
\hline & Actual & & & \\
\hline
\end{tabular}

5/3/97

Figure 3-19. Project performance metrics - measuring the to-be process during implementation. 


\section{Benefits Delivery Commitment}

\begin{tabular}{|c|c|c|c|c|}
\hline \multirow[t]{2}{*}{ Category } & \multicolumn{2}{|c|}{ FY'98 } & \multicolumn{2}{|c|}{ FY '98-'02 } \\
\hline & FTES & Dollars & FTES & Dollars \\
\hline $\begin{array}{l}\text { Annual Funding for permit } \\
\text { modification }\end{array}$ & 2 & $\$ 300,000$ & 2 & $\$ 1,460,000$ \\
\hline Training not required by regulations & & $\begin{array}{l}\$ 265,000 \\
(42 K \text { Hard } \\
223 K \text { Soft })\end{array}$ & 4 & $\$ 1,325,000$ \\
\hline $\begin{array}{l}\text { Maintenance in excess of regulatory } \\
\text { requirements }\end{array}$ & 1 & $\begin{array}{l}\text { up to } \\
\$ 50,000\end{array}$ & & $\$ 250,000$ \\
\hline Totals & 3 & $\$ 615,000$ & 6 & $\$ 3,035,000$ \\
\hline
\end{tabular}

Figure 3-20. Benefits delivery commitment - quantitative and qualitative cost benefit. 


\section{Benefits Delivery Commitment}

\section{RWMC RCRA Part B Permit/ Maintenance}

- Recommendation: Maintenarice activities that exceed the RWMC RCRA Part B Permit requirements will be prudently reduced to a level consistent with the intent of the permit.

In FY ' 97 - Relamping activities will be reduced to the extent consistent with sound business practices. Other inspection activities will be consolidated as appropriate. Approximate savings of \$20K in FY ' 97.

In FY' 98 - '02 - The reduced maintenance activities will be continued with a savings of approximately $\$ 50 \mid K$ annually.

\section{Benefits Delivery Commitment}

\section{RWMC RCRA Part B Permit/ Permit Modification Funding}

- Recommendation: Funding for Class II and Class III permit modifications will be budgeted only in relation to specific activities that are identified in the RCRA regulations as requiring Class II or Class III permit modifications.

In FY '97 a CCB request will be executed to return the remaining budgeted Class II and Class Ill permit modifications funding (approximately $\$ 70 \mathrm{~K}$ ) for a hard dollar cost savings.

In FY ‘98 - '02, permit' modification funding will be governed by a Memorandum of Understanding between Waste Operations and Environmental Affairs limiting the amount budgeted to activities identified in the RCRA relations as requiring Class II or Class III permit modification.

Benefits Delivery Commitment RWMC RCRA Part B Permit/ Training

- Recommendation: A rational, defendable decision making process for determining the required training for each $\mathrm{RWMC}$ employee will be developed. Using the process, a determination will be made whether or not to submit a Class II permit modification to the State to change the RWMC training program.

The process will be shared with the Training Team for use in their process to modify training site-wide.

Savings in FY ' 97 will not be realized due to the need for a permit modification. In FY '98 - '02 approximately \$250K per year will be realized in hard dollar savings and operational efficiencies. In FY 998 there will be an initial cost of $\$ 50-60 \mathrm{~K}$ for a permit modification.

Figure 3-21. Benefits delivery commitment detail for each quantifiable recommendation. 


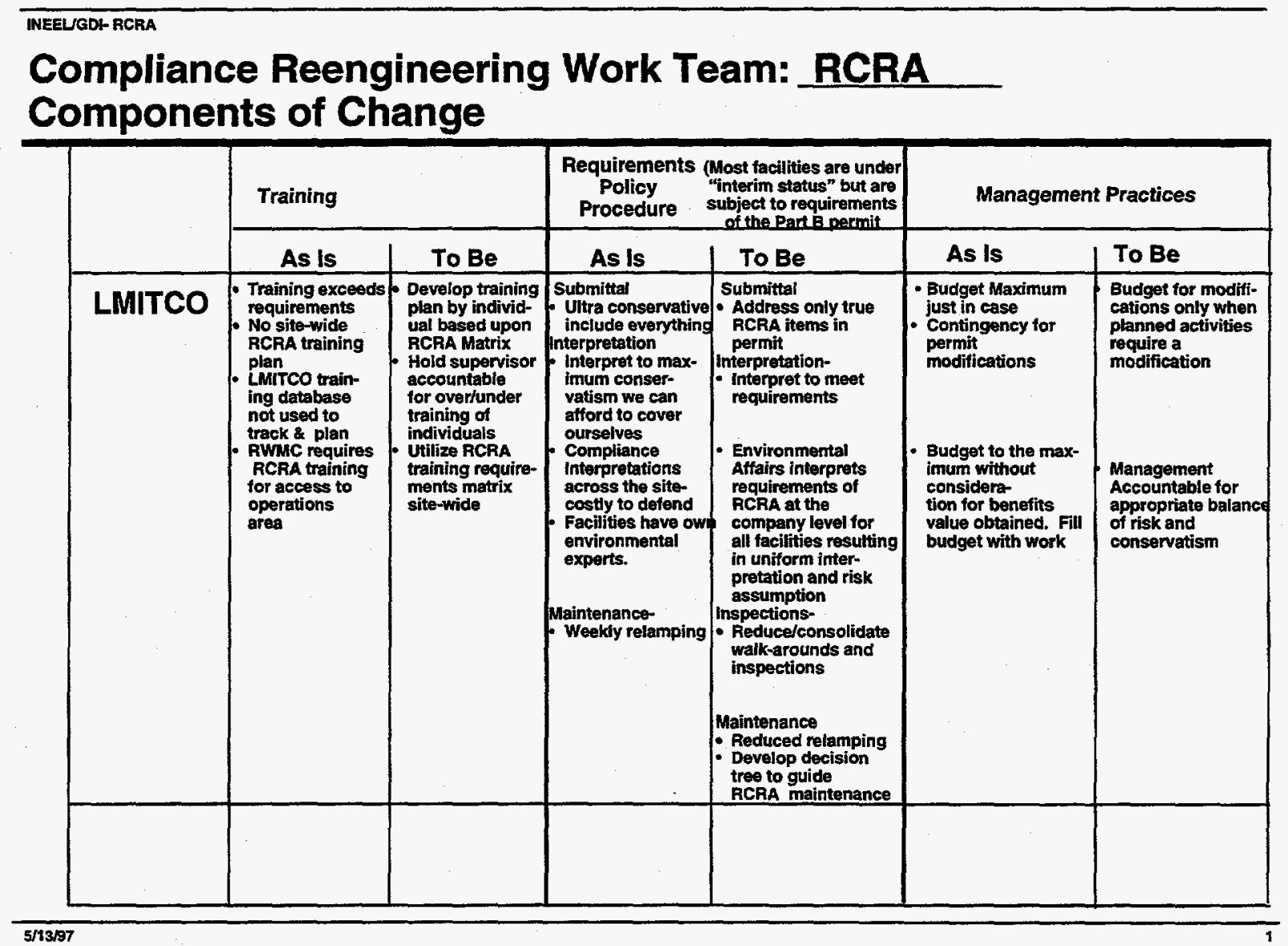

Figure 3-22. Components of change chart showing the as-is and to-be processes. 


\section{RCRA Part B Permit Training/Maintenance "To Be" DACI Chart}

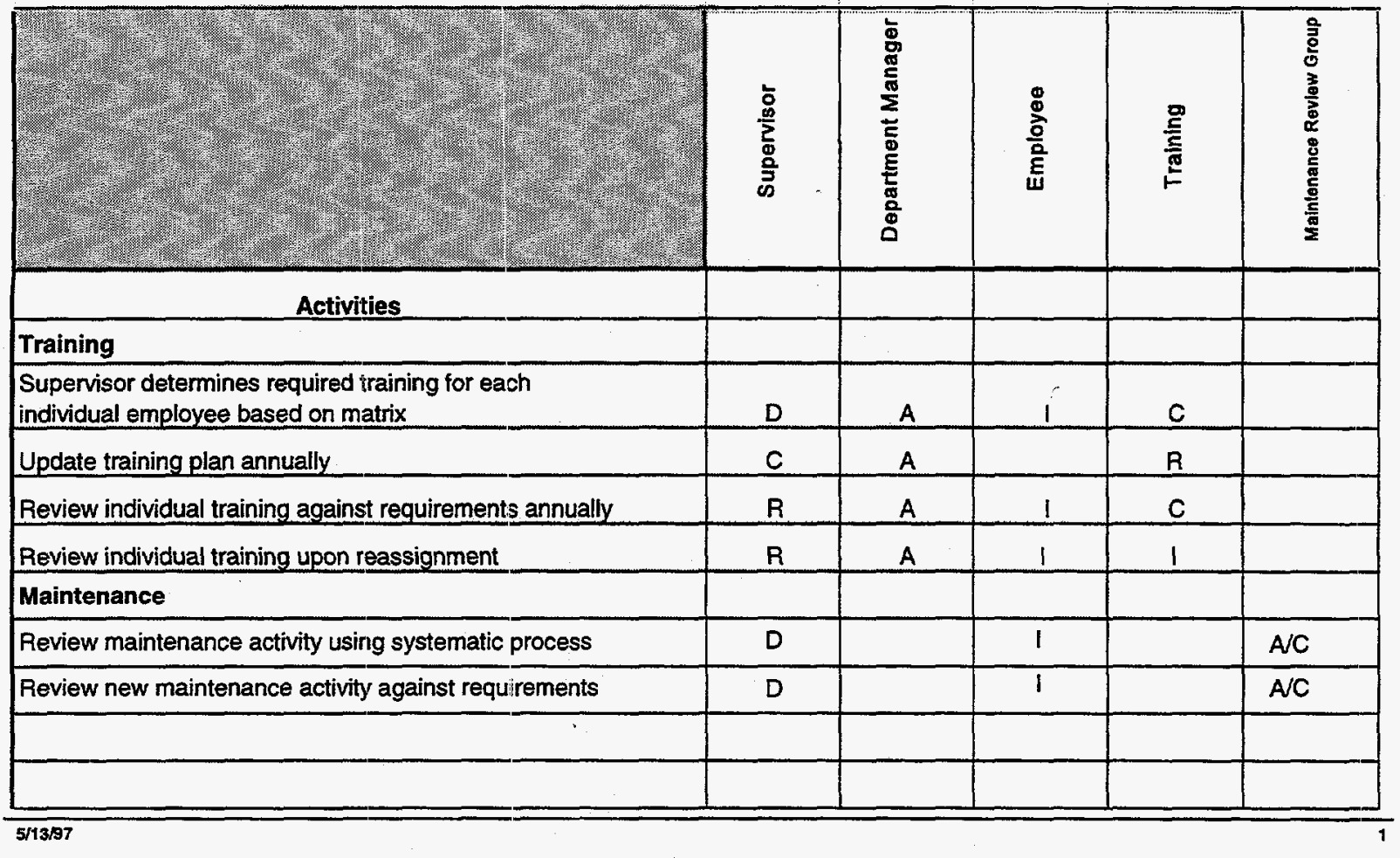
$\mathrm{D}=$ doer
$A=$ accountable
$\mathrm{C}=$ consult
$\mathrm{I}=$ inform
$\mathrm{R}=$ review

Figure 3-23. DACI (doer, accountable, consult, inform) chart showing to-be process roles. 


\subsection{Phase III - Implementation}

During Phase III, from May 1 to October 1, 1997, the implementation plans prepared during Phase II were used to implement and monitor the changes that would decrease Environmental Management program operating costs. The implementation approach for Phase III of the compliance reengineering effort consisted of the following six interrelated activities (illustrated in Figure 3-24):

- Implementation of new work practices

- Communication, mobilization, and integration

- Training and coaching

- Tracking project progress

- Leading the effort

- Instituting continuous improvement

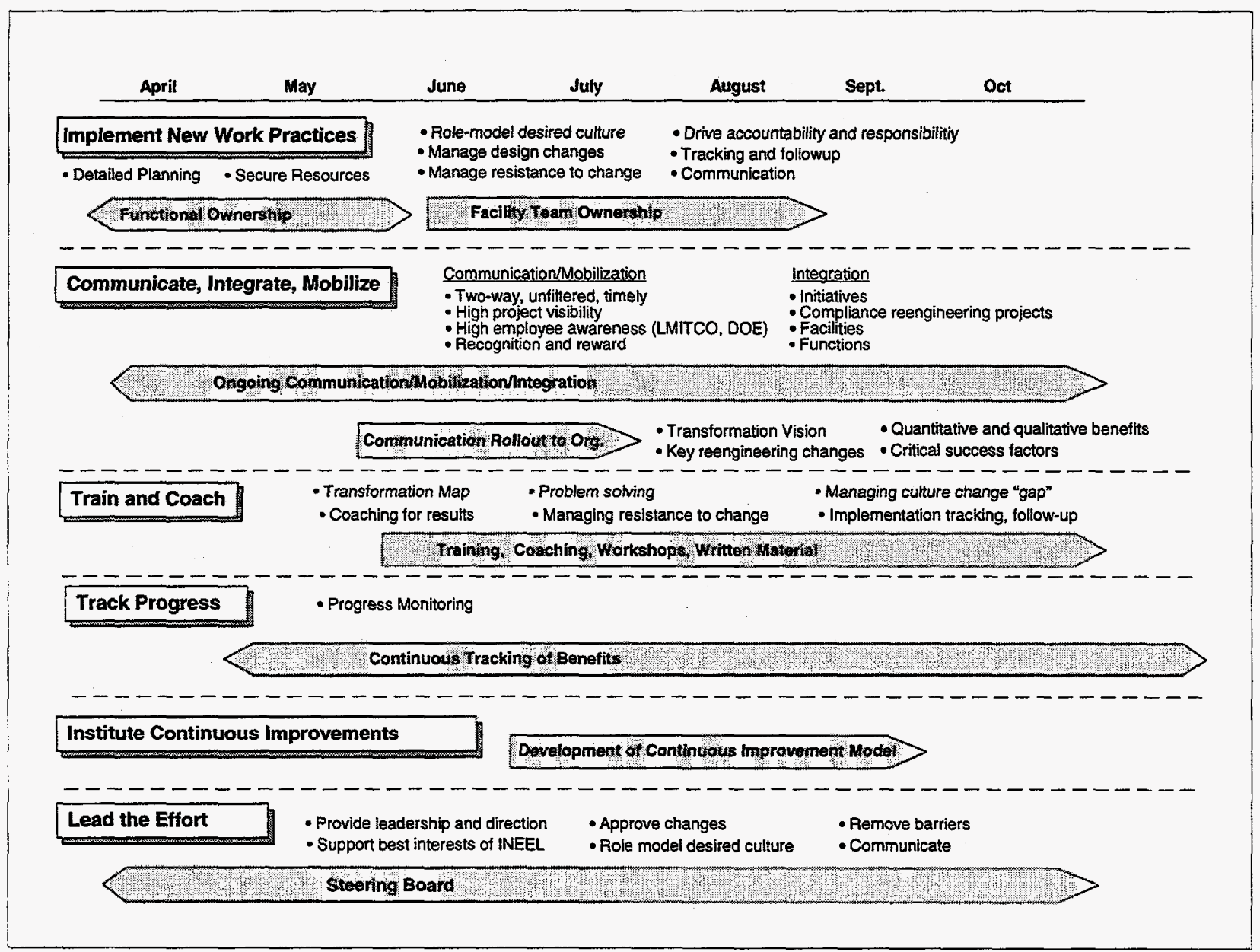

Figure 3-24. Phase III compliance reengineering. 


\subsubsection{Implementation of New Work Practices}

During the initial weeks of Phase III, the detailed implementation plans for each project were finalized, and implementation were resources secured. These resources were identified in Phase II as key process owners from the facilities or departments that will work with the implemented changes. Many of the people involved in Phase III implementation had an active role in Phase II, which helped preserve the continuity and integrity of the changes as they were designed.

Accountability for the successful implementation of compliance reengineering improvements was established and documented through a formal letter from each appropriate senior vice president to the designated director. Each letter contained a listing of the specific deliverables which must be implemented and the corresponding savings. There was also an accountability at the EM project manager level for implementing compliance reengineering improvements and achieving benefit dollars associated with that project.

\subsubsection{Communication and Mobilization}

Large-scale communication and eraployee mobilization efforts were conducted during Phase III to ensure the success of the reengineering effort. The communication and mobilization tools introduced in Phase II and listed in Section 3.3.4 continued to be utilized.

Employees received communications regarding the need for change, implementation successes, and leadership support. The outcomes of the extensive communication efforts were motivation, participation, knowledge, acceptance, support, recognition, and initiative.

A key compliance reengineering mobilization and education tool was a large-scale communication rollout of the INEEL Transformation Map to the Environmental Management organization and DOE. The purpose of these presentations was to communicate the importance and scope of compliance reengineering projects, to communicate why dramatic change is necessary, and show the relationship between and integration of this project and all other key INEEL initiatives. Executive champions, stream leads, team leaders, implementation teams, steering board members, communications team members, and facility managers presented the transformation map throughout the LMITCO and DOE EM organization during Phase III.

\subsubsection{Initiatives Alignment}

There were many other INEEL-wide initiatives in progress during Phase III, including Total Quality Management, Voluntary Protection Program, Projectization, Enhanced Work Planning, Environmental Management System, Integrated Safety Management System, and Self-Assessment. The Change Management Governance Team is working with leaders of other major INEEL-wide initiatives to promote alignment and prevent duplication and conflicting objectives, as indicated in Figure 3-25. An example of successful alignment was the integration of the Enhanced Work Planning Team and the Compliance Reengineering Maintenance Team. The two teams combined into one, and the scope was broadened so that the objectives of both could be met. Another example of successful alignment was the Projectization initiative, in which four very important deliverables will be produced by successfully implementing the Compliance Reengineering Project Management Phase III Plan. 
A process for periodically evaluating the effectiveness of ongoing initiatives and considering potential new initiatives was recommended by the Compliance Reengineering and is being reviewed by LMITCO senior management. That process is shown in Figure 3-26.

\subsubsection{Training and Coaching}

During Phase III, implementation team members, selected steering board members, and EM executives received training and coaching on topics which address emotional, political, and technical barriers to successful implementation. Among the topics covered were Managing Resistance to Change; Coaching for Results; and Implementation Tracking, Follow-up, and Sustaining the Gains.

\subsubsection{Tracking Project Progress}

Regular tracking and reporting of individual project performance against budget, as well as accrual of benefit dollars continued throughout Phase III. Benefits were tracked by benefit-tracking forms, supported by approved CCBs (change control board) and letters. The benefit-tracking form listed the improvement process, the estimated savings, the date the savings will begin, documented hard-dollar (quantitative) and soft-dollar savings (qualitative) savings. The resulting benefit analysis reflected actual approved savings and savings remaining to be realized. These tracked benefit savings were used to:

- Document commitment of projected savings and provided a basis for holding people accountable

- Report savings progress to stream leads, LMITCO management, and DOE

- Indicate implementation timeliness and effectiveness

- Distinguish between hard/soft dollar quantitative/qualitative benefits

\subsubsection{Leading the Effort}

The Compliance Reengineering Steering Board, comprised of both LMITCO and DOE members, continues to provide guidance, decisions, and direction which helped ensure the overall success of the project. Their role is to focus on that which is for the good of the INEEL, versus turf protection and personal agendas. Additionally, steering board members serve as role models for the desired culture change, removed barriers to implementation, and actively participated in communication efforts.

\subsubsection{Instituting Continuous Improvement}

Compliance reengineering, in cooperation with the INEEL Institute's Total Quality Management (TQM) organization, is developing a plan to help continuous improvement become "a way of life" within Environmental Management. This will help the EM organization improve its ability to implement change, and prevent reengineering from becoming a one-time event. This plan will be described in the FY 1998 Compliance Reengineering Report. 


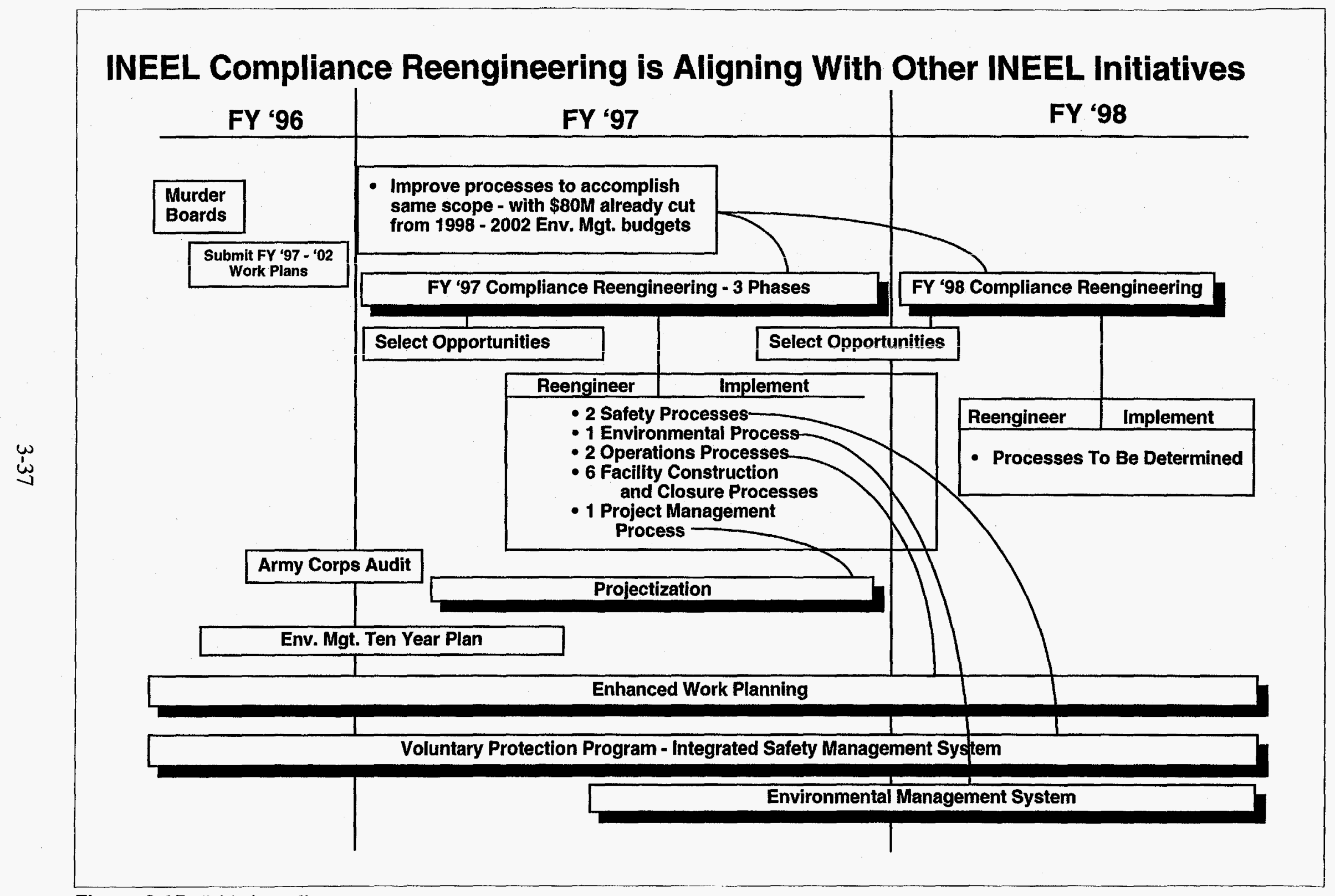

Figure 3-25. Initiatives alignment. 


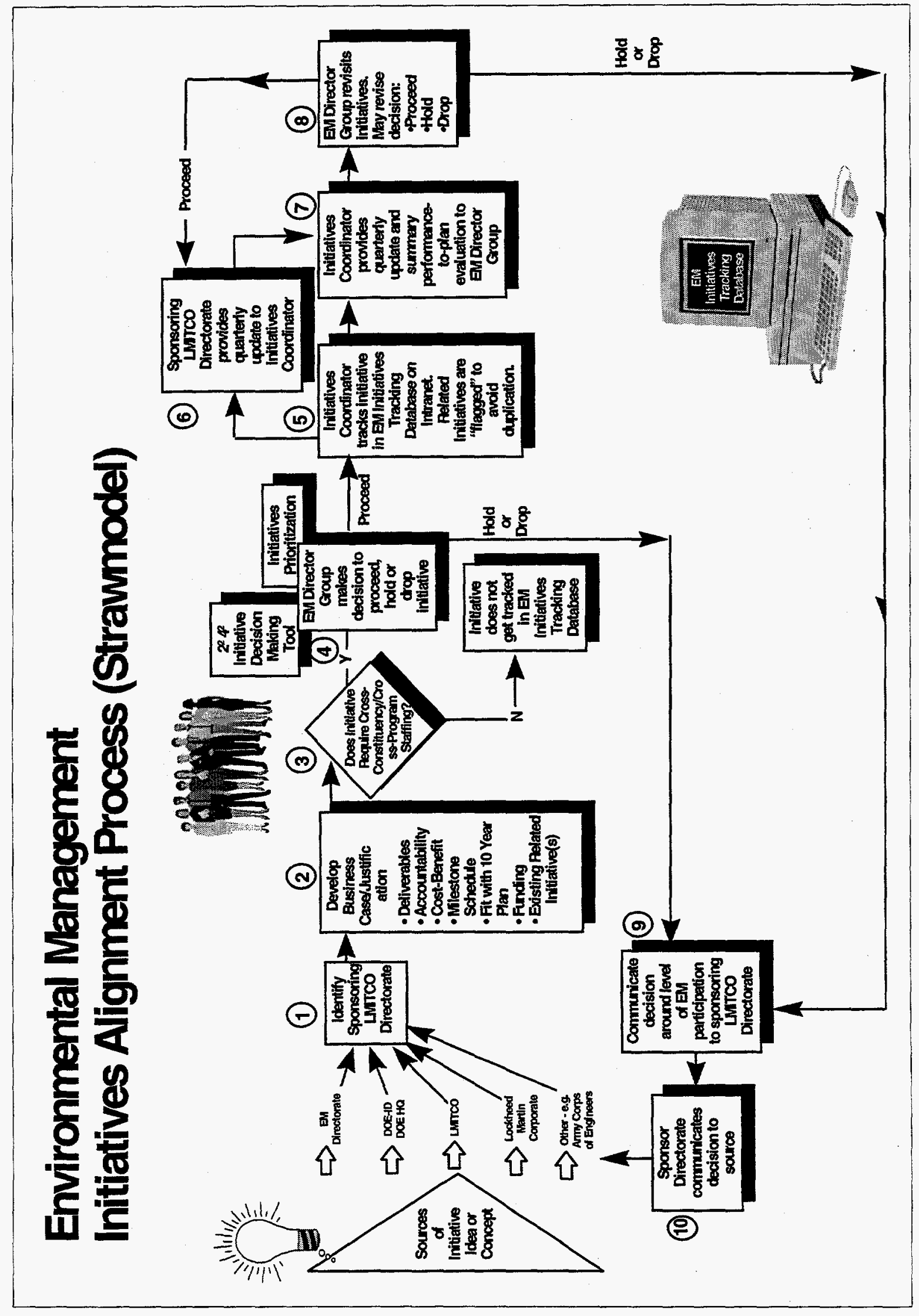

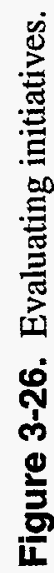




\section{SPECIFIC FY 1997 IMPROVEMENT PROJECTS}

The Phase I reengineering process, which involved significant numbers of INEEL employees, assessed new opportunities in terms of economics and probability of successful implementation. For each reengineering opportunity recommended as a best option for achieving the cost reduction target, the Compliance Reengineering Steering Board evaluated the reengineering benefits, return on investment, and stakeholder value to select the specific improvement projects for Phases II and III.

The opportunities evaluated during compliance reengineering all provide substantial economic benefit. The potential reengineering projects identified in Phase I, grouped into five work streams, had behavioral support from 60 percent or more of the LMITCO and DOE-ID voters, a key factor for successfully implementing change.

During Phase II, the specific improvement projects were revised, and some of the original projects were combined with others or deferred. In Phase III, 12 of the 13 selected reengineering projects were implemented (the quality project was deferred). Of the 12 projects, 7 were completed in FY 1997, and 5 will be completed in FY 1998. Table B-1 (Appendix B) shows the expected benefits of the FY 1997 specific improvement projects at the end of each phase (projects listed in order as selected in Phase I). The final projects for FY 1997 are summarized in Table 4-1 and described in the following subsections. The subsections are sequentially numbered followed by the Phase I project numbers in parentheses. 
Table 4-1. Compliance reengineering summary - FY 1997.

\begin{tabular}{|c|c|c|c|c|c|c|c|}
\hline \multirow[b]{2}{*}{ Stream } & \multirow[b]{2}{*}{ Project } & \multirow[b]{2}{*}{ Section } & \multirow[b]{2}{*}{ As-Is (existing conditions) } & \multirow[b]{2}{*}{ To-Be (reengineering) } & \multicolumn{2}{|c|}{ Benefits (\$M) } & \multirow[b]{2}{*}{ Complete } \\
\hline & & & & & FY-98 & FY.98-02 & \\
\hline \multirow{2}{*}{$\begin{array}{l}\text { I. } \\
\text { Safety }\end{array}$} & $\begin{array}{l}\text { Safety Analysis } \\
\text { Reports (SARs) }\end{array}$ & 4.1 & $\begin{array}{l}\text { SAR updates not consistent, too many revised, } \\
\text { process inefficient }\end{array}$ & $\begin{array}{l}\text { Consistent risk evaluations guidelines, streamlined } \\
\text { updates/upgrades process }\end{array}$ & 9.687 & 17.49 & $3 / 31 / 98$ \\
\hline & $\begin{array}{l}\text { Occurrence } \\
\text { Reporting }\end{array}$ & 4.2 & $\begin{array}{l}\text { Usually use critique, may miss root causes, poor } \\
\text { communication of lessons-learned }\end{array}$ & $\begin{array}{l}\text { Investigators conduct investigation, graded use of } \\
\text { critiques, accelerate pre-final OR completion }\end{array}$ & .262 & 1.0 & $9 / 30 / 97$ \\
\hline $\begin{array}{c}\text { II. } \\
\text { Environmental }\end{array}$ & $\begin{array}{l}\text { RCRA Part B } \\
\text { permit }\end{array}$ & $4 . .3$ & $\begin{array}{l}\text { Excessive permit updating, training, } \\
\text { preventative maintenance }\end{array}$ & $\begin{array}{l}\text { Reduce permit requirements, required preventive } \\
\text { maintenance, training }\end{array}$ & .483 & 2.485 & $5 / 31 / 97$ \\
\hline \multirow{2}{*}{$\begin{array}{l}\text { III. } \\
\text { Operations }\end{array}$} & Training & 4.4 & Excessive training, costly training delivery & Streamine requirements and delivery & 1.33 & 6.645 & $3 / 15 / 98$ \\
\hline & Maintenance & 4.5 & $\begin{array}{l}\text { Redundant procedures, non-value-added } \\
\text { preventive maintenance, inconsistent } \\
\text { scheduling, different work control processes }\end{array}$ & $\begin{array}{l}\text { Standardize scheduling system, optimize PM } \\
\text { performance, improve work order requests, } \\
\text { implement standardized performance measures to } \\
\text { maintain improvements }\end{array}$ & 1.403 & 9.257 & $7 / 31 / 98$ \\
\hline \multirow{6}{*}{$\begin{array}{l}\text { IV. } \\
\text { Facility } \\
\text { Construction } \\
\text { and Closure }\end{array}$} & $\begin{array}{l}\text { Shorten Project } \\
\text { Time Frame }\end{array}$ & 4.6 & Planning and execution costly & $\begin{array}{l}\text { Single LMITCO Project Initiation \& Prioritization } \\
\text { system, project team approach }\end{array}$ & .4 & 2.0 & $9 / 30 / 97$ \\
\hline & $\begin{array}{l}\text { Integration of } \\
\text { Facility Closure }\end{array}$ & 4.7 & $\begin{array}{l}\text { RCRA, CERCLA, FDI closure activities not } \\
\text { integrated }\end{array}$ & Integrate closure activities, eliminate duplication & .12 & 3.7 & $9 / 30 / 98$ \\
\hline & $\begin{array}{l}\text { LMTTCO/Parsons } \\
\text { Review Process }\end{array}$ & s 4.8 & Redundant reviews & $\begin{array}{l}\text { Eliminate one Parsons review cycle and reduce } \\
\text { participation in the IRC process }\end{array}$ & .3 & 1.475 & $9 / 30 / 97$ \\
\hline & $\begin{array}{l}\text { LMITCO/Parsons } \\
\text { Project } \\
\text { Management } \\
\text { Interface }\end{array}$ & 4.9 & Duplicate positions, roles, and responsibilities & $\begin{array}{l}\text { Eliminate duplication, org. structure for PM, software } \\
\text { and effort for project controls }\end{array}$ & 2.242 & 11.21 & $9 / 30 / 97$ \\
\hline & $\begin{array}{l}\text { LMITCO/Parsons } \\
\text { Project } \\
\text { File/Vendor Data } \\
\text { Management }\end{array}$ & 4.10 & $\begin{array}{l}\text { Duplicate organizations, excessive volume, } \\
\text { inefficient process }\end{array}$ & Single vendor data, one document system, one library & .183 & .914 & $9 / 30 / 97$ \\
\hline & $\begin{array}{l}\text { Environmental } \\
\text { Restoration Ad } \\
\text { Hoc Requests }\end{array}$ & 4.11 & Inefficient ad hoc request process & $\begin{array}{l}\text { Screen and track ad hoc requests, eliminating } \\
\text { duplicate effort for responses }\end{array}$ & .15 & .8 & $9 / 30 / 97$ \\
\hline $\begin{array}{c}\text { V. } \\
\text { Business/ } \\
\text { Project } \\
\text { Management }\end{array}$ & $\begin{array}{l}\text { Project } \\
\text { Management } \\
\text { Systems }\end{array}$ & 4.12 & $\begin{array}{l}\text { Project management process and system not } \\
\text { standardized; several project management } \\
\text { software packages used in EM; no PM roles } \\
\text { and responsibilities; no PM career path; project } \\
\text { manager job title applied with no specific } \\
\text { criteria }\end{array}$ & $\begin{array}{l}\text { Standardize PM processes by life-cycle planning, } \\
\text { program office; implement one project management } \\
\text { software as EM standard; establish specific project } \\
\text { manager roles and responsibilities; establish project } \\
\text { manager advisory board to establish and maintain } \\
\text { criteria for project managers; establish PM job family }\end{array}$ & 3.9 & 43.1 & $12 / 97$ \\
\hline TOTAI & & & & & 20.46 & 100.076 & \\
\hline
\end{tabular}




\subsection{Safety Analysis Reports $(\# 1,2)$}

\subsubsection{Purpose}

The purpose of the safety analysis reports reengineering project was to reengineer the approach to consistent site-wide selection of safety controls and risk evaluation in safety analysis reports (SARs).

\subsubsection{Scope}

The scope of the project was to develop a consistent, site-wide approach to the selection of safety structures, systems, and components (SSCs), technical safety requirements (TSRs), and risk evaluation guidelines and to identify efficiencies in SAR preparation, annual updates, and upgrades to comply with new DOE orders.

\subsubsection{Major Phase II SAR Activities}

The SAR project team held a value engineering workshop to clarify all requirements for safety analyses and their documentation, to generate a consistent process to prepare, review, and approve safety analyses, and to generate risk evaluation criteria on a consistent, site-wide basis. From the as-is analysis, the SAR team found that the process of revising and updating SARs was inconsistent. The team recommended a consistent process of revising and updating SARs that complies with all requirements, and process owners validated the to-be SAR process. Implementation required training analysts on the site-wide guidelines, the database, and the new SAR preparation process and revising the SAR preparation procedure. This reengineered SAR process is being implemented at all the INEEL facilities that prepare and use safety analysis reports and technical safety requirements, including the Radioactive Waste Management Complex (RWMC), Waste Experimental Reduction Facility (WERF), Waste Reduction Operations Complex (WROC), Idaho Chemical Processing Plant (ICPP), Test Reactor Area (TRA) non-reactor facilities, and Test Area North (TAN).

\subsubsection{As-is/To-Be Analysis}

The results of the as-is/to-be analysis are shown in Table 4.1.4.

Table 4.1.4. Safety Analysis Reports reengineering project components of change.

\begin{tabular}{l|l}
\hline \multicolumn{1}{c|}{ As-Is } & \multicolumn{1}{c}{ To-Be } \\
\hline \multicolumn{2}{c}{ SAR Upgrades/Updates } \\
\hline $\begin{array}{l}\text { Each facility has separate and different SAR } \\
\text { upgrade/update processes }\end{array}$ & $\begin{array}{l}\text { Consistent site-wide guidelines for upgrading/updating } \\
\text { SARs }\end{array}$ \\
\hline $\begin{array}{l}\text { LMITCO prepares SARs independent of DOE; } \\
\text { SARs prepared by analysts and reviewed by } \\
\text { others }\end{array}$ & $\begin{array}{l}\text { LMITCO/DOE team prepares SAR, scopes contents, } \\
\text { resolves issues, and approves SAR, reducing rejection } \\
\text { rate and review process; revise SAR preparation process } \\
\text { to make more cost-effective }\end{array}$ \\
\hline Each facility has separate SAR review criteria & Consistent site-wide review criteria \\
\hline
\end{tabular}


Table 4.1.4. (continued).

\begin{tabular}{l|l}
\hline \multicolumn{1}{c|}{ As-Is } & \multicolumn{1}{c}{ To-Be } \\
\hline DOE reviews not appealed & $\begin{array}{l}\text { Assign LMITCO/DOE SAR steering board to resolve } \\
\text { issues }\end{array}$ \\
\hline \multicolumn{1}{|c}{ SAR Upgrades/Updates } \\
\hline All SARs updated annually & $\begin{array}{l}\text { Update SARs biennially, instead of annually, or only by } \\
\text { letter after technical change review indicates no change }\end{array}$ \\
\hline Standard SAR sections not available & $\begin{array}{l}\text { Establish site-wide computerized database of standard } \\
\text { SAR sections }\end{array}$ \\
\hline
\end{tabular}

Technical Safety Requirements (TSRs)

\begin{tabular}{l|l}
\hline $\begin{array}{l}\text { TSRs for safety features to avoid extreme } \\
\text { releases that exceed DOE orders }\end{array}$ & Define TSRs using site-wide guidelines \\
\hline
\end{tabular}

\section{Consistent Approach}

\begin{tabular}{l|l}
\hline $\begin{array}{l}\text { SAR problems not defined across INEEL; no } \\
\text { consistent INEEL approach to defining the } \\
\text { safety envelope }\end{array}$ & Implement consistent approach to define safety envelope \\
\hline Graded approach not applied & Apply graded approach of DOE orders \\
\hline
\end{tabular}

\subsubsection{Major FY 1997 Phase III Activities}

Three of the activities have been completed and the other two will be completed early in FY 1998. The project includes the following five deliverables:

- Generation and implementation of a site-wide SAR implementation plan (complete)

- Annual SAR updates to be evaluated and letter written when no significant changes need to be made instead of revising the SAK (complete)

- Implementation of a team effort for SAR preparations (scheduled for completion 4/3/98)

- Implementation of an electronic database of standard chapters and requirements tracking (scheduled for completion 3/6/98)

- Implementation of site-wide risk evaluation guidelines for all SAR preparation and revisions (completed).

The changes that produced cost savings from the improvements completed in FY 1997 have been incorporated into the current budget preprarations for FY 1998. The work identified to be eliminated and the efficiencies in SAR preparation have been factored into the lowered activity-based budgets in the form of reduced funding for those activities. The balance of the improvements that will be completed in FY 1998 will be factored into the budget planning and preparation as cost savings for FY 1999. The personnel who write and revise SARs evaluated the changes and prepared the cost avoidance and savings estimates for this project. The description of the improvements and the associated changes are provided in a table that also identifies implementation tracking metrics that will be used to ensure that benefits are achieved and improvements are sustained. 
Site-wide SAR Implementation Plan. The generation and implementation of a site-wide SAR implementation plan has allowed an exemption to the requirement to upgrade fifteen SARs to the new DOE 5480.22 and 5480.23 orders. The facilities that will receive the exemptions are in a state of cold standby waiting for the decontamination and dismantling (D\&D) activities to begin. Upgrading to the new DOE orders is not required because the facilities will no longer operate. The budgets for FY 1998 were prepared without the funding for the upgrades. The exemptions provide a significant cost avoidance of $\$ 7,692 \mathrm{~K}$ in FY 1998.

Annual SAR Updates. The DOE orders that direct the preparation of the SARs require an annual update. Both the order and the LMITCO management control procedure (MCP) allow the evaluation of the SAR and submittal of the update by letter. The reengineering effort has established acceptance of this practice by the DOE customer, and the efficiency will be begin by the end of FY 1997 . The cost savings are $\$ 45 \mathrm{~K}$ in FY 1998 and \$90 K annually for years FY 1999 through FY 2002.

Team Preparations of SARs. A team will be established to prepare SARs with the responsibility of each team member to assist in the document preparations or revisions, and each team member will also obtain assistance from experts in their organizations to reduce review and approvals to one cycle. The savings using the team approach will be $\$ 300 \mathrm{~K}$ annually starting in the second half of FY 1998.

Implementation of an Electronic Database. The INEEL will have standard site description chapters of SARs that are approved by DOE-ID and can be used in every SAR that is prepared and revised. These standard descriptions can be applied to all safety documents used across the INEEL. There will be chapters that define how the company applies safety programs across the INEEL, which will be approved by DOE-ID and can be used in any SAR that is prepared and revised. Having the chapters preapproved by the DOE-ID SAR committee will eliminate the writing, review, and approval cycle for at least eight of the SAR chapters. The chapters for actual analysis will have company-defined standard approaches for evaluating events using approved seismic, geological, risk evaluation guidelines, etc., allowing timely preparation and review of the SAR revisions and preparations. The database will also provide the traceability and linking of requirements from safety regulations and requirements to contents of safety documents that control work at LMITCO. The standard SAR chapters will allow a one-time savings of $\$ 1,650 \mathrm{~K}$ in FY 1998 as three new SARs are written and seven other SARs are upgraded. The standard chapters will also produce annual savings of $\$ 1,560 \mathrm{~K}$ as 50 other safety documents are prepared and revised each year.

INEEL Risk Evaluation Guidelines. The reengineering effort has established a single risk evaluation guideline that defines the risk limits controls for all INEEL facilities. All nuclear and nonnuclear Category II and III facilities will be evaluated for risks and control measures will be taken to protect workers, the public, and the environment to the same level across the INEEL. The standard risk evaluation guidelines are the first set applied across an entire DOE site, anywhere in the DOE complex. The cost savings for this improvement is realized in the electronic database savings.

Total annual savings from these improvements will be $\$ 9,687 \mathrm{~K}$ for FY 1998 , and $\$ 1,950 \mathrm{~K}$ annually for FY 1999 through FY 2002 (detailed in Table 4.1.8). The cost savings projected for FY 1998 will help to minimize the anticipated shortfall in funding for the all Environmental Management programs. 


\subsubsection{Major FY 1998 Phase III Activities}

The majority of actions for SAR improvements were completed in FY 1997. Two activities from this project will carry over into FY 1998 . The team approach to SAR preparation and revision will continue as an ICPP improvement effort. The second activity will be the completion of standard SAR chapter approval and the application and completion of the institutionalization of the safety requirement tracking and linking system. This second effort is being pursued as a reengineering activity in FY 1998. The effort for tracking and linking requirements has been named the Safety Hazard Analysis Management Utility (SHAMU).

The SHAMU is an innovative electronic methodology that uses existing computer software and platforms to greatly change and improve the way the INEEL creates and manages the multitude of safety analysis documents. This project will enable the INEEL to develop requisite safety analysis documents and analyses more technically consistent and more efficiently. It will enhance safety and environmental compliance and provide better safety awareness and management, at the same time saving significant dollars. The SHAMU will have site-wide accessibility from any personal computer and will be easy to use by both analysts and management, inexpensive to maintain, and transparent to regulators, auditors, and the public.

\subsubsection{Documentation of Results and Savings}

The status of the Phase III activities for SAR improvements were reported to J. VanVliet by T. A. Mathews, the executive champion, by letter TAM-137-97. The letter defines the major activities and their status and defines the economic impact of the changes.

\subsubsection{Estimated Financial Benefit and Measurement Metrics}

The estimated financial benefits after the Phase III work of the reengineered SAR process are as follows:

FY 1998

$\$ 9.687$ million
FY 1998-2002

$\$ 17.49$ million

Implementation details and metrics are provided in Table 4.1.8.

Table 4.1.8. Safety Analysis Reports reengineering project implementation benefits and tracking.

Note: Assumed \$75/hour labor rate.

\section{Site-Wide SAR Implementation Plan Upgrade Exemptions}

Implementation Benefits:

\begin{tabular}{|l|l|l|}
\hline \multicolumn{1}{|c|}{ Activity } & Implementation Date & \multicolumn{1}{c|}{ Benefit Goal } \\
\hline - Site-wide implementation of SAR & Implemented 9/30/97, budgets & Cost avoidance of \\
Implementation Plan allows 15 SARs to & for upgrades eliminated, & $\$ 7,692,000$ in FY-98 \\
be exempt from updates to DOE Orders & DOE-HQ approval of \\
5480.22 and 5480.23 & exemption list expected 1/30/98 & \\
\hline
\end{tabular}


Table 4.1.8. (continued).

Implementation Tracking:

\begin{tabular}{|l|l|l|l|l|}
\hline $\begin{array}{l}\text { Implementation Process } \\
\text { Performance Indicators }\end{array}$ & Metric & Baseline & Commitment & Data Source \\
\hline $\begin{array}{l}\text { Do not perform the } \\
\text { upgrades to the DOE Order } \\
\begin{array}{l}5480.22 \text { and 5480.23 } \\
\text { formats for the 15 SARs. }\end{array}\end{array}$ & $\begin{array}{l}\text { Time } \\
\text { required for } \\
\text { the upgrades }\end{array}$ & $\begin{array}{l}\text { Budgets for FY-98 } \\
\text { have targets } \\
\text { reduced from } \\
\text { FY-97 for this work }\end{array}$ & 102,560 hours & $\begin{array}{l}\text { SAR } \\
\text { preparation } \\
\text { and revision } \\
\text { organizations }\end{array}$ \\
\hline
\end{tabular}

\section{Annual SAR Updates}

Implementation Benefits:

\begin{tabular}{|l|l|l|}
\hline \multicolumn{1}{|c|}{ Activity } & Implementation Date & \multicolumn{1}{c|}{ Benefit Goal } \\
\hline $\begin{array}{l}\text { Implement requirement for annual updates only when } \\
\text { the SAR has significant change, otherwise a letter } \\
\text { stating that evaluation has shown no update required }\end{array}$ & $9 / 30 / 1997$ & $\begin{array}{l}\text { \$45 K FY-98 } \\
\text { \$9 K FY-99 and } \\
\text { annually }\end{array}$ \\
\hline
\end{tabular}

Implementation Tracking:

\begin{tabular}{|c|c|c|c|c|}
\hline $\begin{array}{l}\text { Implementation Process } \\
\text { Performance Indicators }\end{array}$ & Metric & Baseline & Commitment & Data Source \\
\hline $\begin{array}{l}\text { Submit letters in FY-97 for } 5 \\
\text { facility-specific SARs and } 3 \\
\text { general plant SARs } \\
\text { - Submit letters in FY-98 for } 10 \\
\text { facility-specific SARs and } 6 \\
\text { general plant SARs }\end{array}$ & $\begin{array}{l}\text { Reduction in total } \\
\text { time spent updating } 8 \\
\text { SARs in FY-97, and } \\
16 \text { in FY-99 and each } \\
\text { year thereafter }\end{array}$ & $\begin{array}{l}\text { The time for } \\
\text { SARs updates } \\
\text { will be reduced } \\
\text { from current } \\
\text { budgets. }\end{array}$ & $\begin{array}{l}600 \text { hours in } \\
\text { FY }-97 \\
1200 \text { hours in } \\
\text { FY }-98\end{array}$ & $\begin{array}{l}\text { SAR } \\
\text { preparation } \\
\text { and revision } \\
\text { organizations }\end{array}$ \\
\hline
\end{tabular}

\section{Team SAR Preparation and Review Improvements}

Implementation Benefits:

\begin{tabular}{|l|l|c|}
\hline \multicolumn{1}{|c|}{ Activity } & Implementation Date & Benefit Goal \\
\hline - Complete revision of technical standards and MCP & Begin team approach & $\$ 300 \mathrm{~K}$ annually \\
revision to allow team SAR revision and preparation & $4 / 1 / 98$ & \\
- Train analysts and support team members on team process & & \\
- Begin the team revision and preparation process & & \\
\hline
\end{tabular}

Implementation Tracking:

\begin{tabular}{|c|c|c|c|c|}
\hline $\begin{array}{l}\text { Implementation Process } \\
\text { Performance Indicators }\end{array}$ & Metric & Baseline & Commitment & Data Source \\
\hline $\begin{array}{l}\text { - DOE approval of technical standard } \\
\text { changes } \\
\text { - LMITCO approval of MCP changes } \\
\text { - Implement team effort for SAR } \\
\text { revision or preparation } \\
\text { - Team procedure is being followed }\end{array}$ & $\begin{array}{l}\text { Reduced } \\
\text { FTE time to } \\
\text { write SARS }\end{array}$ & $\begin{array}{l}4 / 1 / 98 \\
\text { Begin team } \\
\text { approach }\end{array}$ & 4,000 hours & $\begin{array}{l}\text { SAR } \\
\text { preparation } \\
\text { and revision } \\
\text { organizations }\end{array}$ \\
\hline
\end{tabular}


Table 4.1.8. (continued).

SAR Electronic Database/INEEL Risk Evaluation Guidelines

Implementation Benefits:

\begin{tabular}{|c|c|c|}
\hline Activity & Implementation Date & Benefit Goal \\
\hline $\begin{array}{l}\text { - Standard SAR chapters for } \\
\text { descriptions and institutional } \\
\text { program implementation } \\
\text { - Standard SAR analysis } \\
\text { approach chapters } \\
\text { - Requirements tracking }\end{array}$ & $1 / 1 / 98$ & $\begin{array}{l}\$ 1,650 \mathrm{~K} \text { one-time savings for new SARs } \\
\text { and remaining upgrades for nuclear } \\
\text { facilities, } 30 \text { nonnuclear SAR updates and } \\
\text { preparation. } \\
\$ 1,560 \text { annual savings, including revision } \\
\text { and preparation of } 50 \text { other safety } \\
\text { documents using the standard chapter } \\
\text { descriptions and processes }\end{array}$ \\
\hline
\end{tabular}

Implementation Tracking:

\begin{tabular}{|c|c|c|c|c|}
\hline $\begin{array}{l}\text { Implementation Process } \\
\text { Performance Indicators }\end{array}$ & Metric & Baseline & Commitment & Data Source \\
\hline $\begin{array}{l}\text { Use the standard chapters } \\
\text { for the next } 10 \mathrm{SAR} \\
\text { upgrades to DOE } \\
5480.22 \text { and } .23 \text { formats } \\
\text { for nuclear facilities and } \\
30 \text { nonnuclear facilities }\end{array}$ & $\begin{array}{l}\text { Reduced FTE } \\
\text { time charged to } \\
\text { prepare } \\
\text { upgrades }\end{array}$ & $\begin{array}{l}\text { Reduce SAR } \\
\text { upgrade time by } \\
1 / 4 \text { FTE average }\end{array}$ & 22,000 hours & $\begin{array}{l}\text { SAR preparation and } \\
\text { review organizations, } \\
\text { then check people } \\
\text { charging against SAR } \\
\text { work }\end{array}$ \\
\hline $\begin{array}{l}\text { - Use the standard chapters } \\
\text { for } 50 \text { other safety } \\
\text { documents }\end{array}$ & $\begin{array}{l}\text { Reduced FTE } \\
\text { time charged to } \\
\text { prepare safety } \\
\text { documents }\end{array}$ & $\begin{array}{l}\text { Reduced safety } \\
\text { document } \\
\text { preparation time } \\
\text { by } 20 \% \text { of an } \\
\text { FTE average } \\
\end{array}$ & 20,800 hours & $\begin{array}{l}\text { Safety document } \\
\text { preparation and review } \\
\text { organizations, check } \\
\text { people charging against } \\
\text { a SAR work }\end{array}$ \\
\hline
\end{tabular}

Note: Costs associated with initial implementation tracking and follow up will be funded through Change Management Governance.

\subsubsection{Implementation Completion Date}

The reengineered SAR process will be implemented September 30, 1998.

\subsubsection{Major Changes Since Phase I Estimate}

The Phase I FY 1998 estimate of $\$ 6.7$ million decreased to $\$ 3.15$ million. The Phase I FY $1998-2002$ estimate of $\$ 27.76$ million decreased to $\$ 5.30$ million. This decrease was because of the Phase II direction to continue to produce and maintain the operations requirements manuals. The Phase III implementation actions found documents beyond SAR upgrades and updates that will benefit from standardized SAR chapters and additional exemptions from updating fifteen SARs to DOE Orders 5480.22 and 5480.23 formats. The Phase III estimated savings are $\$ 9.687$ million in FY 1998 and $\$ 17.49$ million over the 5 years. 


\subsection{Occurrence Reporting (\#3)}

\subsubsection{Purpose}

The purpose of the occurrence reporting (OR) reengineering project was to examine the occurrence reporting process from notifications to closing corrective actions in order to generate a zero-defects OR program where all DOE timetables are met and recurring events are eliminated. The project team emphasized reducing the number and time lost due to critiques and determined an approach for occurrence reporting that provides effective investigations and corrective actions leading to safe operations and activities.

\subsubsection{Scope}

The scope of the project included all INEEL facilities, to improve the occurrence reporting process and reduce incidents.

\subsubsection{Major Phase II Activities}

The OR project team examined the following activities to determine the as-is process: notification, critiques, investigations, determination of appropriate corrective actions, and closeout of corrective actions. They prepared and presented a brown paper showing the as-is occurrence reporting process, and then validated the process. The team found wide variations of critique and occurrence reporting processes across the INEEL. They developed an improved, more efficient and cost-effective to-be process that complies with all requirements and began preparing a plan to implement the reengineered occurrence reporting process at all INEEL facilities.

\subsubsection{As-Is/To-Be Analysis}

The results of the as-is/to-be analysis are shown in Table 4.2.4.

Table 4.2.4. Occurrence Reporting reengineering project components of change.

\begin{tabular}{l|l}
\hline \multicolumn{1}{c|}{ As-Is } & \multicolumn{1}{c}{ To-Be } \\
\hline $\begin{array}{l}\text { Critiques conducted too early, } \\
\text { sometimes add little value }\end{array}$ & $\begin{array}{l}\text { Reduce the number of critiques and time lost due to ineffective critiques } \\
\text { by using trained investigators when needed }\end{array}$ \\
\hline Graded approach not used & $\begin{array}{l}\text { Apply a graded approach to occurrence reporting, while achieving an } \\
\text { effective response and continuing to promote safe operations and } \\
\text { activities }\end{array}$ \\
\hline $\begin{array}{l}\text { Different occurrence reporting } \\
\text { process used at different } \\
\text { facilities }\end{array}$ & $\begin{array}{l}\text { Follow the same occurrence reporting process at all facilities, while } \\
\text { achieving effective investigations and corrective actions and ensuring safe } \\
\text { operations and activities }\end{array}$ \\
\hline $\begin{array}{l}\text { Root causes not always } \\
\text { properly identified, } \\
\text { investigators not immediately } \\
\text { involved }\end{array}$ & $\begin{array}{l}\text { Investigators conduct fact-finding immediately after an abnormal event } \\
\text { for more disciplined fact-finding and use of critiques, better root cause } \\
\text { analysis, more effective corrective actions; revise procedure; train facility } \\
\text { managers and investigators on the streamlined process and revised } \\
\text { procedure }\end{array}$ \\
\hline
\end{tabular}


Table 4.2.4. (continued).

\begin{tabular}{l|l}
\hline \multicolumn{1}{c|}{ As-Is } & \multicolumn{1}{c}{ To-Be } \\
\hline $\begin{array}{l}\text { Lessons learned from ORs } \\
\text { communicated on database }\end{array}$ & $\begin{array}{l}\text { Communicate and share lessons learned from completed ORs at biweekly } \\
\text { staff meeting of ES\&H directors, which will reduce repeated abnormal } \\
\text { events with similar root causes }\end{array}$ \\
\hline $\begin{array}{l}\text { Focus on direct causes, instead } \\
\text { of root causes }\end{array}$ & $\begin{array}{l}\text { Revise training to focus corrective actions on root causes, instead of direct } \\
\text { causes, so that fewer abnormal events occur }\end{array}$ \\
\hline
\end{tabular}

\subsubsection{Major FY 1997 Phase III Activities}

The project identified and began implementing five areas of improvement. The improvements have been incorporated into LMITCO MCP-190, which controls the occurrence reporting process; the procedure revision has been sent out for review and approval. Improvements will be completed early in FY 1998 for the following improvement areas:

- Encourage completing the reports before the 45-day maximum time limit allowed by DOE.

- Provide guidelines for the application of the critique process as a part of the OR.

- Add institutional steps to the occurrence reporting process to improve the investigation, root cause determination, and corrective action identification.

- Establish and track performance of root cause identification.

- Provide a process that will allow application of corrective actions site-wide, to effect change and improvement beyond the area of the incident.

Improvement savings will begin shortly after the training on the use of the revised MCP, in early FY 1998. The savings will be achieved through reduced reporting due to the improved process for identifying correct root causes and providing corrective actions in the proper places across the INEEL, which will reduce or eliminate recurring incidents and reduce the total number of incidents. The savings from reducing the occurrences by $10 \%$ using the institutionalization of several steps and assessment of the root causes to find and improve problem areas will yield savings of $\$ 320 \mathrm{~K}$ per year. The major problem identified for improvement was root cause analysis to correct the actual problems and using a minimum process for the entire investigation reporting process from the findings through corrective actions. No cost savings will be predicted for operating efficiencies due to reduced occurrences

Reporting Period. The current DOE order allows for a maximum of 45 days to prepare and submit the pre-final report in the occurrence reporting process. The DOE-ID customer asked that the time used to submit the pre-final report be reduced to correct the perception that the INEEL is not responsive in identifying and correcting deficiencies. A review of the time required to submit reports shows that the majority of reports are transmitted to DOE at the end of the 45-day maximum timing. The team felt that a recommendation to complete the report within 14 days should be incorporated in MCP-190. The benefits of the reduced time include driving the corrective action sooner and gathering current data and witness information (when the incident is fresh in everyone's mind); in addition, facility managers are less likely to postpone the report and become pressed to complete it after 40 days have passed. Finally, the reduced time shows the regulators that the INEEL is concerned about correcting deficiencies. 
Guidelines for Critique Process. The critique process was defined and an application standard for critiques will be included in MCP-190. The protocol will define appropriate uses of the critique as support for the investigation of an occurrence. The current use is for anything from information dissemination to fact-finding. The improvement in critique use will assist in the determination of accurate root causes. The use of critiques should be broadened to allow evaluation of actions and identification of positive results that will also improve the operation, not just to find root causes of incidents.

Root Cause and Corrective Actions Institutional Improvements. The facility managers and their personnel who conduct the investigations will be provided an action checksheet in MCP-190. The checksheet will allow for earlier fact-finding and will guide the investigators through the steps of the investigation without the need to remember all the steps or wait for more experienced help to start the process. A standard investigation recording form will also be included to remind the investigator of the minimum steps to be completed for the investigation and report. The department and facility managers involved in investigations and reporting will receive training on the process to provide knowledgeable direction and approval visibility.

Root Cause Tracking. The root causes will be reviewed and assessed each quarter to verify that adequate investigations and findings are establishing correct root causes. This review will allow for correcting problem areas in a timely manner. Problem facilities and personnel can be changed in an expeditious manner to improve the root cause determination process. Determination of actual root causes will also allow for application of proper corrective actions to eliminate the incidents.

Site-wide Corrective Action. In the past, facility managers who had incidents only considered correcting the problems within their sphere of influence and could not effect a change across the site. The new sitewide Issues Communication and Resolution Environment (ICARE) system will allow assignment of corrective actions across the INEEL instead of just correcting deficiencies at one facility. Correcting deficiencies across the site will reduce the total incidents by preventing recurring problems at different facilities. The MCP-190 appendix containing the corrective action determination will be revised to include the evaluation of actions site-wide and use the Process Deficiency Resolution (PDR) process as a tool for proper corrective action application.

\subsubsection{Major FY 1998 Phase III Activities}

The revised MCP for occurrence reporting will be approved, the investigators and facility managers will receive training on the improvement to the process, and occurrence reporting will begin operating with the improvements. The FY 1998 effort will be completed by the company OR coordinator.

\subsubsection{Documentation of Results and Savings}

The status of the Phase III activities for OR improvements were reported to J. A. VanVliet by B. H. Hamilton, the executive champion, by letter BHH-06-97. The letter defines the major activities and the economic impact of the changes. 


\subsubsection{Estimated Financial Benefit and Measurement Metrics}

The estimated financial benefits of the reengineered occurrence reporting process are as follows:

FY 1998

$\$ .262$ million

FY 1998-2002

$\$ 1.0$ million

Implementation details and metrics are provided in Table 4.2.8.

Table 4.2.8. Occurrence Reporting reengineering project implementation benefits and tracking.

Note: Assumed \$75/hour labor rate.

Implementation Benefits:

\begin{tabular}{|l|l|l|}
\hline \multicolumn{1}{|c|}{ Activity } & \multicolumn{1}{|c|}{ Implementation Date } & \multicolumn{1}{|c|}{ Benefit Goal } \\
\hline $\begin{array}{l}\text { Establishing institutional rigor and assessment of root } \\
\text { causes will reduce the occurrences beginning in FY-98. } \\
\text { - FY-96 had } 162 \text { occurrences }\end{array}$ & $10 / 31 / 97$ & Cost savings of \\
- FY-97 is tracking numbers of occurrences as FY-96 & & S in FY-98; \\
- Reduce the occurrences with the rigor and & from occurrence \\
assessments. & & reductions \\
\hline
\end{tabular}

Implementation Tracking:

\begin{tabular}{|l|l|l|l|l|}
\hline $\begin{array}{l}\text { Implementation Process } \\
\text { Performance Indicators }\end{array}$ & Metric & Baseline & Commitment & Data Source \\
\hline $\begin{array}{l}\text { - Train on new MCP improvements. } \\
\text { - Reduce the number of occurrences } \\
\text { by 10\% from the FY-96 number. }\end{array}$ & $\begin{array}{l}\text { Less occurrences } \\
\text { that need } \\
\text { investigation and } \\
\text { reporting. }\end{array}$ & $\begin{array}{l}\text { FY-96 } \\
\text { occurrence } \\
\text { reports. }\end{array}$ & $\begin{array}{l}4,267 \text { hours } \\
\text { ORPS report } \\
\text { of occurrence } \\
\text { reported }\end{array}$ \\
\hline
\end{tabular}

Note: Costs associated with initial implementation tracking and follow up will be funded through Change Management Governance of Compliance Reengineering.

\subsubsection{Implementation Completion Date}

The occurrence reporting process will be implemented by October 31, 1997.

\subsubsection{Major Changes Since Phase I Estimate}

The Phase I FY 1998 estimate of $\$ .262$ million decreased to $\$ 0.14$ million to allow for the initial learning curve. Phase I FY 1998-2002 estimate of $\$ 1.0$ million did not change. The effort identified improvements to the occurrence reporting process that will result in timely and correct identification of root causes and corrective actions that will eliminate or reduce incidents.

The team identified problems with the Issues Management Electronic Database (IMED) system for tracking corrective actions and will coordinate findings with the new ICARE tracking system as part of the occurrence reporting project. 


\subsection{RCRA Part B (\#10)}

\subsubsection{Purpose}

The purpose of the RCRA Part B permit reengineering project was to review the interpretation and implementation of the Resource Conservation Recovery Act (RCRA) Part B permit at the Radioactive Waste Management Complex (RWMC) to eliminate costly unnecessary details and activities not specifically required by the permit to meet 40 CFR 264 ("Protection of the Environment, Standards for Owners and Operators of Hazardous Waste Treatment, Storage, and Disposal") requirements. The project team identified and recommended to management the possibilities for reducing unneeded monitoring, surveillance, record-keeping, training, and maintenance activities.

\subsubsection{Scope}

The scope of the RCRA project included the RWMC RCRA Part B permit (Volume 5).

\subsubsection{Major Phase II Activities}

To determine the as-is RCRA process and its costs, the RCRA project team reviewed the interpretation of the RCRA Part B permit at the RWMC, performed independent validation of inspection requirements, determined the cost of requirements, the unit cost of training, and the total cost for excessive training, coordinated with the training and maintenance reengineering project teams, reviewed the preventive maintenance list, and arranged for a RCRA specialist to perform an independent validation of the preventive maintenance activities not required under RCRA or the permit.

During the as-is analysis, the team found costly unnecessary details that were not specifically mandated by the permit to meet $40 \mathrm{CFR} 264$ requirements and could therefore be eliminated. They found that of the 377 RCRA operational requirements in the permit, 202 of them were not RCRA-related, but may be required for other reasons. At least 117 of the requirements were not funded during the period reviewed. The team estimated that about $\$ 265,000$ is spent annually on training required by the permit, but not required by RCRA. They transferred the training issues to the training project team in the compliance reengineering operations stream for site-wide resolution. They also determined that the existing permit allows some flexibility in preventive maintenance.

The team developed a to-be RCRA process that reduced or eliminated costly, non-value-added, overcompliance activities.

\subsubsection{As-Is/To-Be Analysis}

The results of the as-is/to-be analysis are shown in Table 4.3.4. 
Table 4.3.4. RCRA Part $B$ reengineering project components of change.

\begin{tabular}{l|l}
\hline \multicolumn{1}{c|}{ As-Is } & \multicolumn{1}{c}{ To-Be } \\
\hline $\begin{array}{l}\text { Excessive training not required by RCRA; no site-wide } \\
\text { RCRA training plan; training not tracked; RCRA } \\
\text { training required for access to RWMC operations }\end{array}$ & $\begin{array}{l}\text { Reduce excessive training, consistent with a } \\
\text { site-wide training plan and requirements matrix }\end{array}$ \\
\hline $\begin{array}{l}\text { Non-essential maintenance activities performed } \\
\text { Excessive, maximum RCRA permit modification } \\
\text { funding }\end{array}$ & Reduce non-essential maintenance activities \\
\hline Requirements overly and inconsistently applied & $\begin{array}{l}\text { Reduce RCRA permit modification funding } \\
\text { requirements }\end{array}$ \\
\hline
\end{tabular}

\subsubsection{Major FY 1997 Phase III Activities}

The Phase III activities focused in three areas of improvements:

- Reduction in permit support costs

- Streamlining of RCRA-related maintenance activities

- Streamlining of RCRA-related training

Permit Support Costs. The following process improvements have been implemented at the RWMC for maintenance of the RCRA Part B permit:

- Combined Class 1 and Class 2 modifications

- Eliminated one review and notice of deficiency (NOD) cycle

- Reduced the number of planned modifications

- Implemented automated data gathering for assimilating waste information to prepare reports

- Reduced manual data entry and calculation.

The implementation of these improvements will result in savings of $\$ 300 \mathrm{~K}$ in FY $1998, \$ 274 \mathrm{~K}$ in FY 1999 , and $\$ 296 \mathrm{~K}$ each year in FY 2000 through FY 2002, for a total savings of $\$ 1460 \mathrm{~K}$. The completed implementation and resulting savings were documented in letter TLC-063-97.

RCRA-Related Maintenance. The following improvements have been implemented at the RWMC to streamline RCRA-related maintenance activities:

- Removal of radiation area monitors from selected RCRA operational areas

- Removal of fire hoses from selected RCRA operational areas

- Reconfiguration of waste from intermediate-level transuranic storage facilities (ILTSFs) to waste storage facilities (WSFis), resulting in elimination of costly vault inspections

- Streamlining of selected RCRA-related preventive maintenance procedures

The implementation of these improvements will result in savings of $\$ 158 \mathrm{~K}$ each year in FY 1998 through FY 2001 and $\$ 168 \mathrm{~K}$ in FY 2002 , for a total savings of $\$ 800 \mathrm{~K}$. 
RCRA-related Training. Work to prepare revised training guidance has been performed in conjunction with the training reengineering activity (Section 4.4). When fully implemented, this change will allow a reduction in non-essential training for selected non-affected administrative and support personnel. Specific RCRA-related training targeted for reduction includes OSHA 24-hour HAZWOPER training, OSHA 8hour refresher, HAZMAT refresher, respirator refresher, and Medic First refresher. Full implementation of some of these changes may require a Class 2 modification to the INEEL RCRA Part B permit, which is scheduled for mid-year in FY 1998. The implementation of these improvements will result in savings of $\$ 25 \mathrm{~K}$ in FY 1998 and $\$ 50 \mathrm{~K}$ each year in FY 1999 through FY 2002, for a total savings of \$225 K.

\subsubsection{Major FY 1998 Phase III Activities}

No major activities are planned for FY 1998. Full implementation of the training improvements will be performed as part of the training reengineering activity.

\subsubsection{Documentation of Results and Savings}

The status of the Phase III activities for RCRA Part B improvements were reported to J. A. VanVliet by M. J. Wolters, the executive champion, by letter MJW-126-97. The letter defines the major activities and the economic impact of the changes.

\subsubsection{Estimated Financial Benefit and Measurement Metrics}

The estimated financial benefits of the reengineered RCRA permit process are as follows:
FY 1998
FY 1998-2002
$\$ .483$ million
$\$ 2.485$ million

Implementation details and metrics are provided in Table 4.3.8

Table 4.3.8 RCRA Part B project implementation benefits and tracking.

Note: Assumes $\$ 75 /$ hour labor costs.

\section{Permit Support Costs}

Implementation Benefits:

\begin{tabular}{|c|c|c|}
\hline Activity & Implementation Date & Benefit Goal \\
\hline Reduce RWMC RCRA Part B permit support costs & Completed & $\$ 1460 \mathrm{~K}$ \\
\hline
\end{tabular}

Implementation Tracking:

\begin{tabular}{|l|l|l|l|l|}
\hline $\begin{array}{l}\text { Implementation Process } \\
\text { Performance Indicators }\end{array}$ & Metric & Baseline & Commitment & Data Source \\
\hline $\begin{array}{l}\text { - Combined Class 1 and 2 modifications } \\
\text { - Eliminated one review and NOD cycle }\end{array}$ & $\begin{array}{l}\text { Reduction in total } \\
\text { budget allocated to } \\
\text { - Reduced number of planned } \\
\text { modifications }\end{array}$ & $\begin{array}{l}\text { FY 1997 } \\
\text { budget }\end{array}$ & $\begin{array}{l}\text { \$300 K for } \\
\text { FY 1998 } \\
\text { revision of the } \\
\text { RWMC RCRA }\end{array}$ & Letter \\
- Implemented automated data gathering \\
$\begin{array}{l}\text { for assimilating waste information } \\
\text { required to prepare report } \\
\text { Reduced manual data entry and } \\
\text { calculation }\end{array}$ & Part B permit & & \\
\hline
\end{tabular}


Table 4.3.8. (continued).

RCRA-Related Maintenance

Implementation Benefits:

\begin{tabular}{|c|l|l|}
\hline \multicolumn{1}{|c|}{ Activity } & Implementation Date & Benefit Goal \\
\hline Streamline RCRA-related maintenance activities. & Completed & $\$ 800 \mathrm{~K}$ \\
\hline
\end{tabular}

Implementation Tracking:

\begin{tabular}{|c|c|c|c|c|}
\hline $\begin{array}{l}\text { Implementation Process } \\
\text { Performance Indicators }\end{array}$ & Metric & Baseline & Commitment & Data Source \\
\hline $\begin{array}{l}\text { - Removal of radiation area } \\
\text { monitors from selected RCRA } \\
\text { operational areas } \\
\text { - Removal of fire hoses from } \\
\text { selected RCRA operational areas } \\
\text { Reconfiguration of waste from } \\
\text { ILTSFs to WSFs } \\
\text { - Streamlining of selected RCRA- } \\
\text { related maintenance procedures }\end{array}$ & $\begin{array}{l}\text { - PMs deleted } \\
\text { - PMs deleted } \\
\text { - Inspections deleted } \\
\text { - Reduced hours to } \\
\text { manage and perform } \\
\text { PM procedures }\end{array}$ & $\begin{array}{l}\text { FY } 1997 \\
\text { budget }\end{array}$ & $\begin{array}{l}\$ 40 \mathrm{~K} \text { annually } \\
(533 \text { hours) } \\
\\
\$ 23 \mathrm{~K} \text { annually } \\
(307 \text { hours) } \\
\$ 65 \mathrm{~K} \text { annually } \\
\text { (867 hours) } \\
\$ 30 \mathrm{~K} \text { annually } \\
\text { (400 hours) }\end{array}$ & $\begin{array}{l}\text { FY } 1998 \\
\text { work } \\
\text { package }\end{array}$ \\
\hline
\end{tabular}

\section{RCRA-Related Training}

Implementation Benefits:

\begin{tabular}{|l|l|l|}
\hline \multicolumn{1}{|c|}{ Activity } & Implementation Date & Benefit Goal \\
\hline $\begin{array}{l}\text { Streamline RCRA-related training at the } \\
\text { RWMC. }\end{array}$ & July 1998 & $\$ 225 \mathrm{~K}$ \\
\hline
\end{tabular}

Implementation Tracking:

\begin{tabular}{|l|l|l|l|l|}
\hline $\begin{array}{l}\text { Implementation Process } \\
\text { Performance Indicators }\end{array}$ & Metric & Baseline & Commitment & Data Source \\
\hline $\begin{array}{l}\text { Reduction in non-essential training of } \\
\begin{array}{l}\text { OSHA 24-hour, OSHA 8-hour } \\
\text { refresher, HAZMAT refresher, } \\
\text { respirator refresher, and Medic First } \\
\text { refresher }\end{array}\end{array}$ & $\begin{array}{l}\text { Reduced FTE } \\
\text { enrolled in non- } \\
\text { essential training }\end{array}$ & $\begin{array}{l}\text { FY 1997 } \\
\text { costs }\end{array}$ & $\begin{array}{l}450 \text { hours for } \\
\text { FY 1998 }\end{array}$ & $\begin{array}{l}\text { Revised } \\
\text { personnel } \\
\text { training plans }\end{array}$ \\
\hline
\end{tabular}

\subsubsection{Implementation Completion Date}

The reengineered RCRA Part B process was implemented September 30, 1997, with the exception of the training, which will be fully implemented by July, 1998.

\subsubsection{Major Changes Since Phase I Estimate}

The Phase I FY 1998 estimate of \$1.35 million decreased to \$.483 million. The Phase I FY 1998 through FY 2002 estimate of $\$ 4.8$ million decreased to $\$ 2.485$ million. The estimate has been reduced primarily because of a reduction in potential savings in training due to concerns by facilities that untrained personnel could gain unauthorized access. 


\subsection{Training (\#11)}

\subsubsection{Purpose}

The training reengineering project's goal was to increase operational productivity while supporting high safety performance standards. The project emphasized reducing the unnecessary INEEL training while improving the necessary and added-value training, identifying the costs of training, and recommending solutions to increase training effectiveness and efficiency. Increasing operational productivity required a new approach to interpreting and applying training requirements, decreasing the widespread use of "just-in-case" training, and identifying training delivery options.

\subsubsection{Scope}

The training project team targeted INEEL-wide environment, safety, and health (ES\&H) training at the request of operations and program personnel. Because the INEEL does not have a baseline of training costs, the team could not estimate the cost of ES\&H training nor estimate what percent of training resources are used for ES\&H training.

\subsubsection{Major FY 1997 Phase II Activities}

The project team analyzed and documented the as-is INEEL training process at the INEEL by examining the following items: the external and internal regulations that drive ES\&H training; INEL Institute 1996 Reengineering Report; INEEL Training Matrix; DOE Headquarters training requirements; INEEL training statistics reports; 1997 budget data; and INEEL training process. The team profiled as-is training hours as well as the available cost and industry benchmark data.

The team identified opportunities for efficiency and effectiveness improvements and designed to-be training. The team's activities included meetings with subject matter experts, multiple value engineering workshops with training, operations, and subject matter experts, and identification of over 90 training drivers, such as federal regulations (over $30 \mathrm{CFRs}$ ), nuclear regulations, legal agreements (for example, Batt Agreement), DOE-LMITCO contract and performance evaluation criteria, DOE orders, company policies and procedures (more than 20 management control procedures and more than 20 program requirements documents), and facility-specific policies and procedures. To maximize results, the team coordinated with the following activities: RCRA and maintenance reengineering teams; INEEL Institute (Technical Training and Center for Performance Improvement); projectization project, Enhanced Work Planning, HAZWOPER committee, and safety initiatives such as the Voluntary Protection Program.

The team designed an improved, cost-effective to-be training process that meets the requirements and adds value. The to-be training includes the following key components:

- Training only those who need ES\&H training to perform their jobs

- Emphasizing accountability to perform as trained

- Increasing training efficiency and effectiveness

- Adopting INEEL training performance measures.

The to-be training process will be piloted, then implemented INEEL-wide. 


\subsubsection{As-Is/To-Be Analysis}

The resuits of the as-is/to-be analysis are shown in Table 4.4.4.

Table 4.4.4. Training reengineering project components of change.

As-Is
To-Be

\section{Training Delivery}

- Primarily classroom training

- Some computer-based training

- Limited test-out options

- Redundant material between courses (for example, respirator covered in 3 courses)

- Lack of integration since stove-piped requirements have been implemented in subject area training

- No equivalency options
- Design process reviewed and prioritization tree developed (frequency, difficulty, consequences)

- Graded approach criteria applied to all training

- Training accommodates operational schedules and needs

- Increased use of test-out, CBT, alternative delivery options

- All organizations and customers involved in training methods development, review, and implementation process

- As practical, training offered at each facility to avoid student travel and accommodate operations' shift needs

\section{Accountability}

- At least one mandate of widespread training - If employee does not perform as trained, focus on per year in response to an incident; mandated widespread training often done before incident/accident investigation even complete

- Additional training and meetings held, and new costly procedures instituted, regardless of source of performance problem responsible person, instead of retraining large group of employees

- Personnel accountable for maintaining training qualifications and certifications

- Personnel accountable to perform as trained

Individual Training

- Training is tracked on multiple information systems; information is not universally accessible nor uniformly documented; no universal access to all training plans/records

- Extensive just-in-case training (for example, train all personnel just in case they are needed or just in case they enter certain areas)

- Training audience guidelines leave room for wide variations in interpretation and therefore training decisions
- Train for job-specific and facility-specific requirements; do not overtrain, instead train the employee to perform the job correctly and safely

- Review training plan annually

- Target training audience with precise guidance

- Adopt just-in-time training capability and/or escort capability to resolve crisis needs

- Training needs analysis done with graded approach

- Rebaseline training requirements to evaluate employee needs

- Individual accountability to perform as trained

- Table-top review/process used beyond security and safeguards training organization

\section{Training Audience}

- Considerable just-in-case, unnecessary training and overtraining

- some employees do not need or use the training they receive
- Target training audience; only train those who need the training to perform their jobs

- Establish contingency training capacity to provide just-in-time training

- Provide information training when appropriate, as opposed to training sufficient to perform the job 
Table 4.4.4. (continued).

\begin{tabular}{l|l}
\hline \multicolumn{1}{c|}{ As-Is } & \multicolumn{1}{c}{ To-Be } \\
\hline \multicolumn{2}{|c}{ Training Quality } \\
\hline $\begin{array}{l}\text { Training needs analysis does not drive } \\
\text { identification of training }\end{array}$ & - Improve stakeholder/customer involvement in training \\
- Stakeholders/customers not involved in \\
training identification, design, and \\
$\begin{array}{l}\text { development } \\
\text { Weak links from requirements/regulatory } \\
\text { organizations to Training, resulting in } \\
\text { training crises }\end{array}$ & Periodically review need, delivery, and depth of each \\
course \\
Individual performance on the job not used \\
to establish training plans
\end{tabular}

Budget

- Current charging practices cumbersome and paperwork intensive

- Budget for training and materials

- Responsibility for conducting training within budget

- Difficult to control and manage resources; for example, the Coleman billing does not provide information needed by operations/program management

- Training better able to react to customer needs

- Less paperwork; better information to manage costs

- Improved planning, budget control, and use of training resources

- Time lost chasing accounting issues instead of training

- Indirect-funded groups struggle to pay for training

\section{Training Schedules}

- Courses scheduled without 12-month operations schedule

- Training peaks and valleys

- Limited ability to support emergency demands for training

- No-show rate fairly high; training charges for no-shows and uses trainer time less efficiently

- Productivity losses include travel time to and from classes often on company time, frequent training interrupts work

- Training schedule changes (15-30 adds/deletes/time changes per month)

- Fully integrated long-term operations/program schedules provided to training organization; training scheduled during operations/program slow periods

- Training more responsive to operations needs (for example, just-in-time training is available)

- Increased use of technology and alternative delivery of training

- More flexible qualification and expiration dates (for example, evaluate $+/-1$ month flexibility in annual qualifications, where not prohibited by law or regulation)

- Restructuring of training courses to decrease time away from job and number of interruptions of work (for example, block scheduling) 
Table 4.4.4. (continued).

\begin{tabular}{l|l}
\hline \multicolumn{1}{c|}{ As-Is } & \multicolumn{1}{c}{ To-Be } \\
\hline \multicolumn{2}{c}{ Proficiency and Equivalency } \\
\hline $\begin{array}{l}\text { Limited use of proficiency or equivalency to } \\
\text { avoid unnecessary/redundant training }\end{array}$ & $\begin{array}{l}\text { Take credit for job performance and related training, } \\
\text { eliminating unnecessary training where appropriate }\end{array}$ \\
covered in radiation, respirator, and & $\begin{array}{l}\text { Option to conduct performance review in field to } \\
\text { demonstrate and document proficiency }\end{array}$ \\
HAZWOPER classes) & $\begin{array}{l}\text { Accept equivalent or relevant training from other } \\
\text { courses }\end{array}$ \\
& $\begin{array}{l}\text { Increase use of test-out option } \\
\text { Eliminate redundancy between courses }\end{array}$ \\
\hline
\end{tabular}

\section{INEEL Training Management}

- INEEL Training Management Council (ITMC) has limited, unofficial role; charter exists, but not signed

- Anyone within INEEL can create new training requirements, choose a training delivery method, and identify who must be trained
- Training management board reviews and oversees INEEL training

- Enforce training management board accountability and responsibility for balancing new training requirements and operational needs

- Develop feedback loop

Training Mandates

- Training mandated without funding

- Document unfunded training mandates and track costs

\subsubsection{Major FY 1997 Phase III Activities}

The Phase III activities for training centered on the deliverables listed below:

- Institute executive training board to oversee and integrate training

- Institute tracking of INEEL training time and costs so that the company will have a valid performance baseline in the future

- Revise training audience guidance and implementing documents

- Perform site-wide scrub of training plans and rosters to align training with revised training audience guidance

- Recommend streamlined training delivery methods to reduce costs of attending and delivering compliance-related training

- Recommend block training to decrease total time away from job and reduce the number of times training interrupts operation/programs

\section{Accomplishments in FY 1997:}

- Executive INEEL training board established to ensure integration of company training requirements, policies, and practices; supports company response to corporate training audit (INEEL Institute action)

- Compliance Reengineering Steering Board adopted training reengineering strategy 
- Gained company-wide consensus to revise training audience guidance for nine major ES\&H areas

- Achieved company consensus on training audience guidance for HAZWOPER courses; estimate reducing HAZWOPER attendance from 1200 people per year to $700-800$ people per year

- Achieved company consensus on an additional eight training course audience guidance matrices, with benefits to be validated as the training rosters are scrubbed; consensus areas are asbestos, confined space, fall protection, high energy/electrical safety, packaging and transportation (DOT HAZMAT), lockout/tagout, radiological worker, respirator

- Identified alternatives for company-wide training measurement

- Identified expedited implementation plan to scrub planned training using new training audience guidance

- Supported company effort to revised training audience guidance for proposed environmental courses; company followed the reengineering process, used for HAZWOPER plus other courses, to better target the audience for the new environmental courses proposed by Environmental Affairs.

\subsubsection{Major FY 1998 Phase Ill Activities}

Scrubbing Training Rosters. Fully implement the new training audience guidance, scrubbing the training rosters and removing personnel who by the new guidance do not need specific training. This will be a joint activity by first-line management, facility training managers, and regulatory support personnel.

Alternative Training Delivery and Block Training. Recommend specific alternative training delivery and block training that will increase the effectiveness and efficiency of training.

Improved Training Measurement. Recommend specific training measurement changes.

\subsubsection{Documentation of Results and Savings}

The status of the Phase III activities for FY 1997 training improvements will be reported to J. A. VanVliet by J. E. Hovinga, the training executive champion. The J. Hovinga letter will define the major activities and the economic impact of the changes.

\subsubsection{Estimated Financial Benefit and Measurement Metrics}

The estimated financial benefits (includes cost savings plus cost avoidance) of implementing the reengineered training process are as follows:

FY 1998

$\$ 1.3$ million
FY 1998-2002

$\$ 6.6$ million

The operations and programs organizations will realize the majority of these savings since the greatest cost of training is the time away from the job. Implementation details and metrics are provided in Table 4.4.8. These benefits do not include proposed changes to reengineered environmental training program. 
Table 4.4.8 Training project implementation benefits and tracking.

Note: Assumes $\$ 60 /$ hour labor rate.

\section{INEEL Executive Training Board}

Implementation Benefits:

\begin{tabular}{|l|l|l|}
\hline \multicolumn{1}{|c|}{ Activity } & Implementation Date & \multicolumn{1}{c|}{ Benefit Goal } \\
\hline $\begin{array}{l}\text { Institute and empower new } \\
\text { executive training board to ensure } \\
\text { integration of company training }\end{array}$ & Original date 9/30/97 & $\begin{array}{l}\text { \$165 K savings annually } \\
\text { INEEL will avoid establishing } \\
\text { unwarranted training. }\end{array}$ \\
\hline
\end{tabular}

Implementation Tracking:

\begin{tabular}{|l|l|l|l|l|}
\hline $\begin{array}{l}\text { Implementation Process Performance } \\
\text { Indicators }\end{array}$ & Metric & Baseline & Commitment & Data Source \\
\hline $\begin{array}{l}\text { Approved executive training board charter } \\
- \text { authority and scope established } \\
\text { - Board members appointed }\end{array}$ & $\begin{array}{l}\text { Board members } \\
\text { analyzing and } \\
\text { voting on site- } \\
\text { wide training }\end{array}$ & $\begin{array}{l}\text { voting by } \\
10 / 97\end{array}$ & $\begin{array}{l}2,750 \text { hours } \\
\text { of course time } \\
\text { eliminated }\end{array}$ & $\begin{array}{l}\text { Training time } \\
\text { avoidance for } \\
\text { Operations } \\
\text { personnel }\end{array}$ \\
\hline
\end{tabular}

\section{Training Measurement}

Implementation Benefits:

\begin{tabular}{|l|l|l|}
\hline \multicolumn{1}{|c|}{ Activity } & Implementation Date & \multicolumn{1}{c|}{ Benefit Goal } \\
\hline $\begin{array}{l}\text { Institute and enforce tracking of training } \\
\text { time and costs to provide the INEEL with } \\
\text { a valid performance baseline }\end{array}$ & $\begin{array}{l}\text { second quarter, } \\
\text { FY } 1998\end{array}$ & $\begin{array}{l}\text { Cost-benefit neutral . Essential } \\
\text { for INEEL to manage use of } \\
\text { training resources. }\end{array}$ \\
\hline
\end{tabular}

Implementation Tracking:

\begin{tabular}{|l|l|l|l|l|}
\hline $\begin{array}{l}\text { Implementation Process } \\
\text { Performance Indicators }\end{array}$ & Metric & Baseline & Commitment & Data Source \\
\hline $\begin{array}{l}\text { Report with training hours/cost } \\
\text { - Scope: training delivery and } \\
\text { attendance }\end{array}$ & $\begin{array}{l}\text { Cost-benefit neutral. } \\
\text { Essential for INEEL } \\
\text { to rnanage use of } \\
\text { training. }\end{array}$ & $\begin{array}{l}\text { Begin tracking } \\
\text { costs third } \\
\text { quarter } \\
\text { Frequency: monthly }\end{array}$ & $\begin{array}{l}\text { No reduction } \\
\text { in hours }\end{array}$ & TBD \\
\end{tabular}

\section{Training Requirements}

Implementation Benefits:

\begin{tabular}{|l|l|l|}
\hline \multicolumn{1}{|c|}{ Activity } & Implementation Date & \multicolumn{1}{c|}{ Benefit Goal } \\
\hline $\begin{array}{l}\text { Revise training audience } \\
\text { guidance for nine major ES\&H } \\
\text { areas }\end{array}$ & $9 / 30 / 97$ & $\begin{array}{l}\text { Cost-benefit neutral activity, but a } \\
\text { prerequisite to scrub of training; } \\
\text { application of graded approach to } \\
\text { training audience critical to reducing } \\
\text { unnecessary compliance training. }\end{array}$ \\
\hline
\end{tabular}


Table 4.4.8. (continued).

Implementation Tracking:

\begin{tabular}{|c|c|c|c|c|}
\hline $\begin{array}{l}\text { Implementation Process } \\
\text { Performance Indicators }\end{array}$ & Metric & Baseline & Commitment & Data Source \\
\hline $\begin{array}{l}\text { - Training guidance - defines } \\
\text { who needs HAZWOPER } \\
\text { training } \\
\text { - Revised training audience } \\
\text { guidance INEEL training } \\
\text { matrix } \\
\text { - Policy/procedures to implement } \\
\text { new training guidance }\end{array}$ & $\begin{array}{l}\text { Cost-benefit neutral. } \\
\text { Application of } \\
\text { graded approach to } \\
\text { training audience } \\
\text { critical to reducing } \\
\text { unnecessary } \\
\text { compliance training. }\end{array}$ & $\begin{array}{l}\text { Complete } \\
\text { revised training } \\
\text { matrix } 9 / 30 / 97 \\
\text { issue matrix as } \\
\text { company policy } \\
\text { by } 11 / 1 / 97\end{array}$ & $\begin{array}{l}\text { No reduction } \\
\text { in hours }\end{array}$ & $\begin{array}{l}\text { not } \\
\text { applicable }\end{array}$ \\
\hline
\end{tabular}

\section{Scrubbing Training Rosters}

Implementation Benefits:

\begin{tabular}{|l|l|l|}
\hline \multicolumn{1}{|c|}{ Activity } & Implementation Date & \multicolumn{1}{c|}{ Benefit Goal } \\
\hline $\begin{array}{l}\text { Perform site-wide scrub of training } \\
\text { plans/rosters to align training with revised } \\
\text { training audience guidance requirements. }\end{array}$ & $12 / 1 / 97$ & $\begin{array}{l}\text { \$910 K savings annually; INEEL } \\
\text { will focus its training resources } \\
\text { on those who need training }\end{array}$ \\
\hline
\end{tabular}

Implementation Tracking:

\begin{tabular}{|c|c|c|c|c|}
\hline $\begin{array}{l}\text { Implementation Process } \\
\text { Performance Indicators }\end{array}$ & Metric & Baseline & Commitment & Data Source \\
\hline $\begin{array}{l}\text { Scrubbed training plans } \\
\text { per revised guidance }\end{array}$ & $\begin{array}{l}\text { Reduce hours } \\
\text { Operations personnel } \\
\text { spend in training; } \\
\text { reduce training delivery }\end{array}$ & $\begin{array}{l}\text { Begin } \\
\text { reducing } \\
\text { hours } \\
12 / 97\end{array}$ & 15,167 hours & $\begin{array}{l}\text { Training time } \\
\text { reduced for } \\
\text { operations } \\
\text { personnel and } \\
\text { training personnel }\end{array}$ \\
\hline
\end{tabular}

Alternative Training Delivery

Implementation Benefits:

\begin{tabular}{|l|l|l|}
\hline \multicolumn{1}{|c|}{ Activity } & Implementation Date & \multicolumn{1}{c|}{ Benefit Goal } \\
\hline $\begin{array}{l}\text { Recommend streamlined training } \\
\text { delivery methods to reduce the costs } \\
\text { of attending and delivering } \\
\text { compliance-related training. }\end{array}$ & third quarter FY 1998 & $\begin{array}{l}\text { \$225 K savings annually. Technical } \\
\text { Training owns the related CPAF } \\
\text { criteria to reduce FY 1997 training } \\
\text { costs compared with FY 1996 }\end{array}$ \\
\hline
\end{tabular}

Implementation Tracking:

\begin{tabular}{|c|c|c|c|c|}
\hline $\begin{array}{l}\text { Implementation Process } \\
\text { Performance Indicators }\end{array}$ & Metric & Baseline & Commitment & Data Source \\
\hline $\begin{array}{l}\text { - Recommended additional alternative } \\
\text { delivery for specific courses } \\
\text { - New alternatives available to classroom } \\
\text { courses (Technical Training) } \\
\text { - Recommended program for } \\
\text { HAZWOPER equivalency courses }\end{array}$ & $\begin{array}{l}\text { Reduce hours } \\
\text { Operations } \\
\text { personnel spend } \\
\text { in training }\end{array}$ & $\begin{array}{l}\text { Began } \\
\text { reducing } \\
\text { hours in } \\
\text { FY } 1997\end{array}$ & 3,750 hours & $\begin{array}{l}\text { Training } \\
\text { time reduced } \\
\text { for all } \\
\text { INEEL } \\
\text { personnel }\end{array}$ \\
\hline
\end{tabular}


Table 4.4.8. (continued).

\section{Block Scheduled Training}

Implementation Benefits:

\begin{tabular}{|l|l|l|}
\hline \multicolumn{1}{|c|}{ Activity } & Implementation Date & \multicolumn{1}{c|}{ Benefit Goal } \\
\hline $\begin{array}{l}\text { Recommend block training to decrease time away } \\
\text { from job and reduce the number of training } \\
\text { interruptions to Operations/Programs. }\end{array}$ & third quarter FY 1998 & $\begin{array}{l}\text { Savings to be determined } \\
\text { in concert with training } \\
\text { functions. }\end{array}$ \\
\hline
\end{tabular}

Implementation Tracking:

\begin{tabular}{|l|l|l|l|l|}
\hline $\begin{array}{l}\text { Implementation Process } \\
\text { Performance Indicators }\end{array}$ & Metric & Baseline & Commitment & Data Source \\
\hline $\begin{array}{l}\text { Recommendations for block- } \\
\text { scheduled courses: INEEL } \\
\text { and/or facility-specific }\end{array}$ & $\begin{array}{l}\text { Savings to be } \\
\text { determined in concert } \\
\text { with training functions }\end{array}$ & $\begin{array}{l}\text { Begin } \\
\text { reducing hours } \\
\text { in FY 1998 }\end{array}$ & $\begin{array}{l}\text { Technical } \\
\begin{array}{l}\text { Training to } \\
\text { implement }\end{array}\end{array}$ & $\begin{array}{l}\text { not } \\
\text { applicable }\end{array}$ \\
\hline
\end{tabular}

\subsubsection{Implementation Completion Date}

The training reengineering project will be implemented by March 31, 1998.

\subsubsection{Major Changes Since Phase I Estimate}

The Phase I project team estimated a FY 1998 savings of \$3.0 million and FY 1998-2002 savings of $\$ 12.2$ million. With more information, the Phase II team decreased the estimated savings. The Phase II team projected a FY 1998 savings of $\$ 1.3$ million and FY 1998-2002 savings of \$6.6 million. That savings projection remained constant in Phase III.

The training reengineering project team and the INEEL Institute's Center for Performance Improvement are collaborating on the EM-1 and ES\&H Training Improvement Partnership Pilot. The INEEL is one of three DOE sites selected for this training pilot. The INEEL is awaiting the DOE Headquarters funding decision.

The HAZWOPER committee took responsibility for analyzing and revising the HAZWOPER course content and for implementing an equivalency program. The committee made its recommendations but does not yet have an estimate of the savings.

The compliance reengineering training team supported the reengineering of the proposed environment training program developed by Environrnental Affairs and Technical Training. At the request of operations and programs, the joint effort reevaluated the training audience guidance and recommended some changes in course content and the implementation schedule.

The Lockheed Martin corporate training audit of INEEL training resulted in a company plan to establish an executive training board ancl expedited the consolidation of training records, and the streamlining of training. The INEEL training board was chartered and members were chosen in September 1997. 


\subsection{Maintenance $(\# 12,16)$}

\subsubsection{Purpose}

The purpose of the maintenance reengineering project was to streamline the maintenance process to eliminate redundant procedures, eliminate non-value-added preventive maintenance procedures, simplify existing procedures, and bring support-to-worker ratio in line with industry standards.

\subsubsection{Scope}

The scope of the maintenance project included maintenance activities performed at INEEL EM-funded nonreactor, nuclear facilities including RWMC, ICPP, WERF/WROC, and TAN. Specific maintenance improvements will be piloted at the RWMC.

\subsubsection{Major Phase II Activities}

To evaluate the as-is maintenance program process, the maintenance project team completed a value engineering study set up a war room, and prepared charts documenting the process.

To develop the to-be maintenance process, the team prepared a vision statement for maintenance excellence, defined and developed performance measures and standards and criteria for maintenance excellence at the INEEL, validated performance measures and performance indicators with RWMC line management and maintenance support personnel, and conducted a value engineering workshop to identify potential improvements, cost benefits, critical success factors, interfaces, implementation issues, and requirements. The team designed an improved, cost-effective maintenance process that reflects maintenance excellence for the INEEL and complies with all requirements and a detailed implementation plan to achieve the desired improvements. The team validated the to-be process with maintenance personnel at RWMC to prepare for implementation.

\subsubsection{As-Is/To-Be Analysis}

The results of the as-is/to-be analysis are shown in Table 4.5.4.

Table 4.5.4. Maintenance reengineering project components of change.

\begin{tabular}{l|l}
\hline \multicolumn{1}{c|}{ As-Is } & \multicolumn{1}{c}{ To-Be } \\
\hline $\begin{array}{l}\text { The current maintenance scheduling process is } \\
\text { different at each facility and inconsistently applied } \\
\text { resources }\end{array}$ & $\begin{array}{l}\text { Implement standardized, integrated (long-range, } \\
\text { medium-range, and short-range) detailed site-wide } \\
\text { scheduling system and software for labor and } \\
\text { non-labor resources that is linkable between projects } \\
\text { and supports projectization; prioritize work orders; } \\
\text { this will improve control and coordination of } \\
\text { resources, optimize staffing levels, provide timely } \\
\text { forecasts based on needs, improve backlog } \\
\text { management, improve responsiveness to customer } \\
\text { needs }\end{array}$ \\
\hline
\end{tabular}


Table 4.5.4. (continued).

As-Is
Preventive maintenance is conducted periodically
and has not been optimized with regard to system,
structure, and component (SSC) condition, needs, or
programmatic risk

job complexity or job hazards

Improve preventive maintenance program by

eliminating unnecessary and duplicate preventive

maintenance procedures and activities; consolidate

preventive maintenance procedures to optimize

resource use while maintaining appropriate level of

control and oversight; optimize periodic

maintenance activities by incorporating predictive

and reliability maintenance concepts

The level of work planning is the same regardless of

Develop and implement a graded approach that

clearly identifies the level of planning required

based on the complexity and hazards of the job

(skill of the craft vs. team planning including

involvement of the crafts personnel)

Work control processes are different at each of the

INEEL facilities; workers moving from one facility to the next must adapt to different methods and requirements for accomplishing work

Develop a standardized work control process that includes common procedures, common roles and responsibilities, common terminology, identical computer maintenance management system (CMMS) and scheduling systems, common hazard identification tool, identical work control forms, and common priority system

Work order requests are low in quality and not complete; planners spend time trying to understand the request

Screen work order requests prior to entry into work control system to ensure quality and completeness and to improve use of time and resources; standardize work request format

There is no effective performance measurement system to track and evaluate maintenance

Measure maintenance activities by developing and implementing a standardized performance measurement system, baselining maintenance activities to developed indicators, comparing activities with industry standards, trending indicators to measure effectiveness of maintenance improvement initiatives, and ensuring that data is available

\subsubsection{Major FY 1997 Phase III Activities}

The Phase III activities have focused in four areas of improvement:

- Developing and implementing standardized site-wide maintenance performance indicators

- Developing and piloting a standardized preventive maintenance optimization process

- Procuring a standardized Computer Maintenance Management System (CMMS) for site-wide use

- Implementing specific maintenance enhancements at the RWMC.

Maintenance Performance Indicators. A set of maintenance performance indicators were developed by an INEEL cross-functional team and implemented site-wide to provide management with a standardized 
tool to measure performance against targets and to take corrective actions where necessary. The measures also allow the baselining of current maintenance performance across the site in order to quantify and maintain the effect of continuous improvement activities.

Maintenance Optimization Process. A standardized process has been selected for the evaluation, justification, and optimization of a facilities preventive maintenance process. Approximately 30 individuals have been trained in the process and a pilot program has been performed at the ICPP to implement learned principles.

Computer Maintenance Management System. A modern CMMS system has been procured to provide a standardized platform for all maintenance activities at the INEEL.

RWMC Maintenance Enhancements. The following improvements have been implemented at the RWMC as a result of the projectization and compliance reengineering activities:

- Improved process for work control resulting in reduction of work order administration

- Streamlined preventive maintenance procedures

- Eliminated funding for discretionary facility modifications

The implementation of these improvements will result in savings of $\$ 830 \mathrm{~K}$ each year in FY 1998 through FY 2002, for a total savings of $\$ 4140 \mathrm{~K}$.

\subsubsection{Major FY 1998 Phase III Activities}

FY 1998 activities include support for site-wide implementation of the standardized department-level performance indicators for maintenance activities. The preventive maintenance optimization pilot will be completed at an INEEL facility and the learned principles will be implemented at the following facilities: ICPP, TAN, RWMC, WERF/WROC, and CFA. Work will also continue to complete implementation of the standardized CMMS system. Projected savings from implementation of the maintenance optimization process and CMMS are \$573 K in FY 1998 and \$1136 K each year in FY 1999 through FY 2002, for a total savings of $\$ 5117 \mathrm{~K}$.

\subsubsection{Documentation of Results and Savings}

The status of the Phase III activities for Maintenance improvements were reported to J. A. VanVliet by P. S. Yela, the executive champion, by letter PSY-22-97. The letter defines the major activities and the economic impact of the changes.

\subsubsection{Estimated Financial Benefit and Measurement Metrics}

The estimated financial benefits of the reengineered maintenance process are as follows:

FY 1998

$\$ 1.403$ million
FY 1998-2002

$\$ 9.257$ million

Implementation details and metrics are provided in Table 4.5.8. 
Table 4.5.8. Maintenance reengineering project implementation benefits and tracking.

\section{Maintenance Performance Indicators}

Implementation Benefits:

\begin{tabular}{|l|c|l|}
\hline \multicolumn{1}{|c|}{ Activity } & Implementation Date & Benefit Goal \\
\hline $\begin{array}{l}\text { Standardize maintenance performance } \\
\text { indicators }\end{array}$ & $10 / 1 / 97$ & $\begin{array}{l}\text { Cost neutral but will provide a } \\
\text { driver to track and reduce costs }\end{array}$ \\
\hline
\end{tabular}

Implementation Tracking:

\begin{tabular}{|l|l|l|l|l|}
\hline $\begin{array}{l}\text { Implementation Process } \\
\text { Performance Indicators }\end{array}$ & Metric & Baseline & Commitment & Data Source \\
\hline $\begin{array}{l}\text { Standardized maintenance } \\
\text { performance measurement } \\
\text { system }\end{array}$ & $\begin{array}{l}- \text { Safety } \\
- \text { Reliability } \\
- \text { Cost-effectiveness } \\
- \text { Responsiveness }\end{array}$ & N/A & N/A & N/A \\
\hline
\end{tabular}

\section{Maintenance Optimization Process}

Implementation Benefits:

\begin{tabular}{|l|l|l|}
\hline \multicolumn{1}{|c|}{ Activity } & Implementation Date & Benefit Goal \\
\hline Maintenance optimization & $6 / 30 / 97$ & $\$ 4460 \mathrm{~K}$ \\
\hline
\end{tabular}

Implementation Tracking:

\begin{tabular}{|l|l|l|l|l|}
\hline $\begin{array}{l}\text { Implementation Process } \\
\text { Performance Indicators }\end{array}$ & Metric & Baseline & Commitment & Data Source \\
\hline $\begin{array}{l}\text { Streamline preventive } \\
\text { maintenance processes at } \\
\text { RWMC, WERF/WROC, } \\
\text { ICPP, TAN, and CFA }\end{array}$ & $\begin{array}{l}\text { - PMs deleted frequency modified } \\
\text { based on risk and } \\
\text { equipment history } \\
\text { Reduced hours to } \\
\text { manage and perform PM } \\
\text { program }\end{array}$ & $\begin{array}{l}\text { FY } 1997 \\
\text { maintenance } \\
\text { budget }\end{array}$ & $\begin{array}{l}\$ 500 \mathrm{~K} \text { in } \\
\text { FY 1998; } \\
\$ 990 \mathrm{~K} \text { for FY } \\
1999-2002\end{array}$ & $\begin{array}{l}\text { FY 1998 } \\
\text { compliance } \\
\text { reengineerin } \\
\text { g report }\end{array}$ \\
\hline
\end{tabular}

\section{Computerized Maintenance Management System}

Implementation Benefits:

\begin{tabular}{|l|l|l|}
\hline \multicolumn{1}{|c|}{ Activity } & Implementation Date & Benefit Goal \\
\hline Standardized CMMS & $9 / 30 / 98$ & $\$ 658 \mathrm{~K}^{*}$ \\
\hline
\end{tabular}

* Note: Additional savings will be achieved upon integration with the FY 1998 Enhanced Work Planning initiative to develop and implement a standardized site-wide work control system. 
Table 4.5.8. (continued).

Implementation Tracking:

\begin{tabular}{|l|l|l|l|l|}
\hline $\begin{array}{l}\text { Implementation Process } \\
\text { Performance Indicators }\end{array}$ & \multicolumn{1}{|c|}{ Metric } & Baseline & Commitment & Data Source \\
\hline Implement standardized & $\begin{array}{l}\text { Reduced administrative } \\
\text { CMMS at INEEL }\end{array}$ & $\begin{array}{l}\text { FY } 1997 \\
\text { budget }\end{array}$ & $\$ 68 \mathrm{~K}$ & TBD \\
& $\begin{array}{l}\text { - Reduced network support } \\
\text { - Reduced training }\end{array}$ & & $\$ 9 \mathrm{~K}$ \\
& - Better utilization of spares \\
& Reduced system maintenance \\
procedures & & $\$ 13 \mathrm{~K}$ & \\
& $\$ 30 \mathrm{~K}$ & \\
& & & \\
\hline
\end{tabular}

\subsubsection{Implementation Completion Date}

The maintenance project will be implemented by June 30, 1998.

\subsubsection{Major Changes Since Phase I Estimate}

The Phase I FY 1998 estimate of $\$ 3.3$ million decreased to $\$ 1.4$ million. The Phase I FY 1998-2002 estimate of $\$ 17.2$ million decreased to $\$ 9.3$ million.

The Enhanced Work Planning (EWP) initiative for the development and implementation of standardized work control practices throughout the INEEL was deferred until FY 1998. The portion of this project that depends on successful implementation of EWP was removed. Note that EWP is funded by Compliance Reengineering in FY 1998. 


\subsection{Shorten General Plant Project (GPP) Time Frame (\#18, 19c)}

\subsubsection{Purpose}

The purpose of the reengineering project to shorten project time frames was to design methods to effectively reduce the overall duration of construction general plant projects (GPP). This reduction in time will result in cost savings without adverse impacts to safety or quality.

\subsubsection{Scope}

The scope of this project was to review the complexities of the GPP process, review operating expense funded projects (OEFP) and capital equipment projects (CEP) that will be active during FY 1998, and introduce methods to promote a systematic graded approach to the project inception, design, construction, and acceptance phases. The project team's design concentrated on construction and waste management projects, while remaining flexible so that concepts can be applied to other company projects if applicable.

\subsubsection{Major Phase II Activities}

The team for the project to shorten project time frames determined the as-is process by reviewing the complexities of the GPP process, developing an as-is flow diagram and validating it, brainstorming potential process improvements, and developing war room charts. The team interfaced with related initiatives teams, such as the project management reengineering team, the INEEL projectization team, and the quality steering team/process improvement team, and consulted stakeholders. The team designed a to-be process to shorten project time frames that ensures safety and quality and complies with requirements. Senior project managers, a projectization representative, a DOE-ID representative, and many other operations, facilities, and support personnel validated the design. The team identified industry benchmarks from the Construction Industry Institute and the Project Management Institute, and they established performance measurements for measuring implementation during Phase III. The team prepared an implementation plan and strategy and identified and validated the project savings.

\subsubsection{As-Is/To-Be Analysis}

The results of the as-is/to-be analysis are shown in Table 4.6.4.

Table 4.6.4. Reengineering project to shorten project time frames components of change.

\begin{tabular}{l|l}
\hline \multicolumn{1}{c|}{ As-Is } & \multicolumn{1}{c}{ To-Be } \\
\hline Prioritization of projects by program & Priocess \\
\hline Project initiation cumbersome & "One stop shopping" for project requester \\
\hline No continuity between project phases & Minimize breaks in project momentum \\
\hline Project activities focused around fiscal year & Plan project activities around construction season \\
\hline DOE-ID makes all critical decisions & DOE-ID makes one critical decision \\
\hline Each phase treated as a deliverable & Phases support end product/construction \\
\hline
\end{tabular}


Table 4.6.4. (continued).

\begin{tabular}{|c|c|}
\hline As-Is & To-Be \\
\hline Annual call letter for request of GPP projects & $\begin{array}{l}\text { Develop continuous standardized site-wide process } \\
\text { for GPP project requests }\end{array}$ \\
\hline Duration approximately 4 fiscal years per project & Duration approximately 3 fiscal years per project \\
\hline \multicolumn{2}{|c|}{ Process } \\
\hline Different players in each part of process & $\begin{array}{l}\text { Same team members throughout process, taking out } \\
\text { the stops }\end{array}$ \\
\hline $\begin{array}{l}\text { Each project is unique with no comparison of } \\
\text { projects }\end{array}$ & Utilize standardized boiler plates \\
\hline Redundant/multiple reviews & In-process team interactive reviews \\
\hline Full-blown conceptual design performed & $\begin{array}{l}\text { Conceptual design effort commensurate with project } \\
\text { complexity }\end{array}$ \\
\hline \multicolumn{2}{|c|}{ Organization } \\
\hline $\begin{array}{l}\text { Each facility and/or program initiates and } \\
\text { prioritizes work requests }\end{array}$ & $\begin{array}{l}\text { Provide single organization for project screening and } \\
\text { prioritization }\end{array}$ \\
\hline Project manager assigned at conceptual phase & Project manager assigned as soon as beneficial \\
\hline $\begin{array}{l}\text { Functional orientation with individual program } \\
\text { focus }\end{array}$ & $\begin{array}{l}\text { Project orientation with site goals, company mission, } \\
\text { and future planning }\end{array}$ \\
\hline $\begin{array}{l}\text { Project manager given responsibility without } \\
\text { authority }\end{array}$ & $\begin{array}{l}\text { Project manager given responsibility with } \\
\text { accountability and authority }\end{array}$ \\
\hline $\begin{array}{l}\text { Support groups do not understand deliverables } \\
\text { (lack of involvement) }\end{array}$ & $\begin{array}{l}\text { Project objectives and support organization } \\
\text { responsibilities are clearly defined }\end{array}$ \\
\hline $\begin{array}{l}\text { Projects tied to specific specialized needs of } \\
\text { facilities, individuals }\end{array}$ & Projects tied to company goals and objectives \\
\hline Project prioritization by crisis & Project priority based on mission need \\
\hline \multicolumn{2}{|c|}{ Procedures and Requirements } \\
\hline No one understands graded approach & $\begin{array}{l}\text { Project core team applies graded approach } \\
\text { commensurate with actual risk }\end{array}$ \\
\hline Zero risk mentality & $\begin{array}{l}\text { Project core team applies graded approach } \\
\text { commensurate with actual risk }\end{array}$ \\
\hline Contain redundancies and conflicts & $\begin{array}{l}\text { Revise requirements to eliminate redundancies and } \\
\text { streamline tasks. Consolidate approximately } 12 \\
\text { project documents }\end{array}$ \\
\hline $\begin{array}{l}\text { Current life cycle asset management (LCAM) } \\
\text { order does include DOE-ID until critical } \\
\text { decision } \# 1\end{array}$ & Include DOE-ID on project team \\
\hline Justification paperwork causes process slow down & $\begin{array}{l}\text { Obtain performing organization's buy-in at } \\
\text { Estimating's Jury Review }\end{array}$ \\
\hline
\end{tabular}


Table 4.6.4. (continued).

\begin{tabular}{l|l}
\hline \multicolumn{1}{c|}{ As-Is } & \multicolumn{1}{c}{ Team Work } \\
\hline \multirow{2}{*}{$\begin{array}{l}\text { Participating organizations do not understand } \\
\text { their deliverables }\end{array}$} & $\begin{array}{l}\text { Project objectives identified and understood by all key } \\
\text { stakeholders }\end{array}$ \\
\hline Team assembles only in design reviews & Project team involved throughout duration \\
\hline \multirow{2}{*}{ Team concept not fully supported } & $\begin{array}{l}\text { All project participants striving to achieve project } \\
\text { goals }\end{array}$ \\
\hline \multirow{2}{*}{$\begin{array}{l}\text { Support organizations not involved in projects at } \\
\text { functions }\end{array}$} & Early, timely involvement of key stakeholders \\
\cline { 2 - 2 } & $\begin{array}{l}\text { Encourage problem resolution rather than problem } \\
\text { identification }\end{array}$ \\
\cline { 2 - 2 } & Core project team established early in planning stages \\
\cline { 2 - 2 } & $\begin{array}{l}\text { Key project stakeholder involvement throughout life } \\
\text { of project }\end{array}$ \\
\cline { 2 - 2 } & $\begin{array}{l}\text { Central Planning organization provides annual work } \\
\text { scope to support organization }\end{array}$ \\
\cline { 2 - 2 } & Early project team involvement curtails scope growth \\
\hline
\end{tabular}

\subsubsection{Major FY 1997 Phase III Activities}

As a result of the team's close contact with other initiatives during Phase $I$, the opportunity to consolidate and integrate with those similar findings was mutually beneficial. The initiatives that were integrated were P/CM directorate QST's roles and responsibilities and project teams. The implementation of the Phase II findings was concentrated on the development of a standard construction project's formulation process and a project's execution and closeout stages. Improvements to the P/CM Directorate Guidebook is an ongoing process, but the team made specific recommendations to the committee (i.e., core team approach, roles and responsibilities, and the quantification of the graded approach). The new project management guide published 9/8/97 includes these improvements.

Although the initiative deferred its recommendation for a central construction project initiation and prioritization entity (a similar recommendation is being worked at an upper management level), the need for viewing the resource requirements for an entire fiscal year was still a necessity and the team has taken on that task. The GPP FY 1998 budget and number of projects uncertainties has caused a reassessment of impacts and projected savings.

Project Formulation. As of September 30, 1997, the effort to standardize the GPP request process is complete. This effort concluded with a computerized initiation form that is user-friendly and can be initiated at any time. The format for the various prioritization lists that are submitted to DOE-ID for approval has also been standardized. A process has also been implemented to analyze an entire fiscal year's GPP activities site-wide and initiate performing organization planning. This will include stakeholder input to organize upcoming GPP information to optimize the construction season and facilitate resource planning for all performing organizations. 
Project Execution. Several changes have been made to the P/CM guidebook that direct efficiencies in the management of GPPs. Specific definitions (1) institute project team concepts and roles and responsibilities, (2) quantify the graded approach to eliminate non-value added activities, (3) initiate more effective design reviews, and (4) use the project baseline estimate as resource documentation for support organization planning.

Project closeout. The P/CM guidebook now promotes efficiency processes in GPP closeout activities. Recommendations to project managers include combining closeout walkthroughs and reviews to reduce redundancies. Closeout planning in the early stages of a project will help to eliminate costly after-the-fact changes.

\subsubsection{Major FY 1998 Phase III Activities}

Tracking and validating the benefits from the team's collective findings will be carried out throughout the fiscal year. There are also various P/CM directorate training programs that will be carried out and the project formulation process will be viewed for resulting improvements.

\subsubsection{Documentation of Results and Savings}

Further analysis of the potential benefits will have to be made after the actual FY 1998 GPP budget has stabilized and the complexity of those projects can be better determined. This is necessary because of the significant reduction in FY 1998 GPPs that were anticipated during Phase II.

Savings are estimated at $3 \%$ to $4 \%$ of the final FY 1998 GPP budget. The savings are documented in the W.A. Baxter letter to J. VanVliet on Compliance Reengineering Implementation (WAB-25-97, dated 9/19/97).

\subsubsection{Estimated Financial Benefit and Measurement Metrics}

The estimated financial benefits of shortening project time frame are as follows:

FY 1998

$\$ .4$ million
FY 1998-2002

$\$ 2.0$ million

The estimated benefit of shortening project time frame is $3 \%$ to $4 \%$ of the GPP final budgets for FY 1998-2002. Both operating and capital expenditures will be tracked for the key findings of this initiative. Variances will be analyzed against the original cost projections. Both variances will be evaluated and categorized to identify the reason and ownership by using checklists and the responsible project manager narratives. Project schedules and durations will also be tracked to determine which activities and processes most effectively maintained construction project momentum and continuity.

Implementation details and metrics are provided in Table 4.6.8. 
Table 4.6.8. Total reengineering project to shorten GPP time frames implementation benefits and tracking.

Implementation Benefits:

\begin{tabular}{|c|l|l|}
\hline \multicolumn{1}{|c|}{ Activity } & Implementation Date & Benefit Goal \\
\hline Reduce duration of GPP projects & $\begin{array}{l}\text { Begin 10/1/97; improvements in project } \\
\text { management guide issued 9/8/97 }\end{array}$ & $\$ 2,000 \mathrm{~K}$ \\
\hline
\end{tabular}

Implementation Tracking:

\begin{tabular}{|c|c|c|c|c|}
\hline $\begin{array}{l}\text { Implementation Process } \\
\text { Performance Indicators }\end{array}$ & Metric & Baseline & Commitment & Data Source \\
\hline $\begin{array}{l}\text { - Reduce GPP project duration to } \\
20 \text { months } \\
\text { - Perform capital expeditive } \\
\text { portion of work in one fiscal } \\
\text { year }\end{array}$ & $\begin{array}{l}\text { Duration of } \\
\text { project } \\
\text { preconception } \\
\text { through } \\
\text { closeout }\end{array}$ & $\begin{array}{l}\text { Projects prior } \\
\text { to FY } 1998 \\
\text { had 24-month } \\
\text { duration }\end{array}$ & $\begin{array}{l}4 \% \text { of project } \\
\text { costs estimate in } \\
\text { combination } \\
\text { with capital } \\
\text { expenditure } \\
\text { changes }\end{array}$ & $\begin{array}{l}\text { FY-98 GPP } \\
\text { budget ( } \$ 10 \\
\text { million), } \\
\text { assume it stays } \\
\text { constant in FY } \\
1999-2002\end{array}$ \\
\hline
\end{tabular}

\subsubsection{Implementation Completion Date}

The shorten GPP time frame process was implemented by September 30, 1997.

\subsubsection{Major Changes Since Phase I Estimate}

The Phase I FY 1998 estimate of $\$ .885$ million increased to $\$ 1.57$ million. The Phase I FY 1998-2002 estimate of $\$ 9.15$ million increased to $\$ 10.0$ million. These changes were due to the number of specific projects expected during the FY 1998-2002 period. The Phase III estimates were reduced because of the small number of projects budgeted in FY 1998. 


\subsection{Integration of Facility Closure (\#19a)}

\subsubsection{Purpose}

The purpose of the reengineering project for the integration of facility closures was to reengineer facility closures to eliminate multiple transfers and plans, and to and integrate the Resource Conservation and Recovery Act (RCRA) and the Comprehensive Environmental Response, Compensation, and Liability Act (CERCLA) requirements for facility closures.

\subsubsection{Scope}

The scope of the project was to integrate the deactivation, facility disposal initiative (FDD) and decontamination and dismantlement (D\&D) processes to eliminate inefficiencies and redundancies and to create an innovative closure process that integrates RCRA and CERCLA requirements.

\subsubsection{Major Phase II Activities}

The reengineering project team for the integration of facility closures analyzed and validated the as-is process. They found that the as-is process is divided among five organizations and two separate funding sources.

To develop the to-be process, the team conducted a problem-solving session, prepared a brown paper, identified critical success factors, and prepared a DACI (doer, accountability, consult, inform) chart and a components of change chart. They developed a to-be closure process that complies with RCRA and CERCLA requirements and eliminates conflicting requirements. The team validated the to-be integrated closure process and gathered 10-year-plan budget information to determine and document the savings of the to-be process. The team prepared an implementation plan and implementation strategy for the new closure process. The team coordinated implementation with the projectization team.

\subsubsection{As-ls/To-Be Analysis}

The results of the as-is/to-be analysis are shown in Table 4.7.4.

Table 4.7.4. Integration of facility closure components of change.

\begin{tabular}{l|l}
\hline \multicolumn{1}{c|}{ As-Is } & \multicolumn{1}{c}{ To-Be } \\
\hline $\begin{array}{l}\text { Closure processes are not } \\
\text { integrated }\end{array}$ & $\begin{array}{l}\text { Integrate the following closure processes: deactivation, D\&D, FDI, } \\
\text { RCRA, CERCLA }\end{array}$ \\
\hline No coordinated closure process & $\begin{array}{l}\text { Fund integrated closure processes under one facility closure } \\
\text { organization, which will coordinate scheduling, budgeting, } \\
\text { prioritization, and use of resources; the centralized closure } \\
\text { organization will reduce management and soils and waste repositories } \\
\text { and eliminate duplicate documents }\end{array}$ \\
\hline $\begin{array}{l}\text { End state for Level 1 and Level 2 } \\
\text { not defined }\end{array}$ & $\begin{array}{l}\text { Define an end state for Level 1 (INEEL) and Level 2 (facility areas, } \\
\text { such as ICPP, RWMC, TAN) areas that will describe the area's end } \\
\text { condition; this will allow integration of engineering design of closure } \\
\text { activities consistent and compatible with the area's defined end state }\end{array}$ \\
\hline
\end{tabular}


Table 4.7.4. (continued).

\begin{tabular}{l|l}
\hline $\begin{array}{l}\text { No closure coordination, no } \\
\text { position assignment }\end{array}$ & $\begin{array}{l}\text { Assign coordinator position, reporting directly to the director of the } \\
\text { closure organization to maintain oversight and coordination of closure } \\
\text { activities and ensure that closure activities are consistent with the } \\
\text { area's end state }\end{array}$ \\
\hline
\end{tabular}

\subsubsection{Major FY 1997 Phase III Activities}

Phase III activities were initiated in FY 1997 and will be completed in FY 1998. A resource-loaded schedule was created for the Phase III projects to implement the three major recommendations: (1) integrate closure organization and funding resources; (2) establish an "end state" for the facility areas for closure projects; and (3) maintain the end states in a living document. Implementation of these three recommendations will create integrated closure projects and subsequent cost savings. A total of $\$ 3.7$ million in cost savings will be generated by FY 2002 . Organization consolidation will achieve $\$ .6$ million and soil repository consolidation will generate $\$ 3.1$ million (in savings). In order to achieve these savings, nine activities were planned, six for FY 1997 and three for FY 1998. In FY 1997, five of the six were completed. The ICPP pilot was also completed in FY 1997, beyond the original scope of the project. The seven activities for FY 1997 are described below.

Level 2 (Facility-Specific) End State Vision. The vision for the end state will be contained in the INEEL Environmental Management End State Flan. This plan will cover the six major INEEL operations or facility areas: Test Area North (TAN), Test Reactor Area (TRA), Idaho Chemical Processing Plant (ICPP), Central Facilities Area (CFA), Power Burst Facility (PBF), and Radioactive Waste Management Complex (RWMC). The vision for the end state plan has been completed and the entire plan will be completed in FY 1998. The plan will contain a chapter for each of the six major facilities, with a drawing showing the end state of the facility for the year 2094 and identification of the major activities and assumptions necessary for that facility to reach the specified end state. This end state vision for each facility is necessary for all the different programs at a facility to work toward a common goal. Developing and implementing the end state vision will produce savings in planning and performance, with reductions in planning, rework, and oversight review. (complete)

ICPP Pilot. It was necessary to revise the schedule to take advantage of the ICPP pilot performed to develop the process and goals of the end state plan. The pilot project was performed to test and refine the requirement, scope, and cost to build the end state plan and is the basis for the detailed end state plan and FY 1998 cost estimate. The changes as a result of the pilot include a clear description of the end state plan scope for the INEEL and how that plan is to be developed. (complete)

Detailed Level 2 End State Vision. The detailed Level 2 end state vision will be included in the six facility-specific chapters of the INEEL End State Plan, to be completed by the end of FY 1998. The detailed end states will include details about the buildings, structures, utilities, CERCLA sites, and infrastructure. Developing the detailed end state plan is the most costly part of this compliance reengineering project and will identify the greatest savings. The process of building the end state plan brings together the different entities necessary to close a building, structure, CERCLA site, or utility at an INEEL facility. This process of bringing together affected parties will result in additional savings. The collection and tracking of these additional savings is part of the scope for this activity. (pilot completed in FY 1997 and plan to be completed in FY 1998) 
Modification of Project Breakdown Structure. The Environmental Restoration (ER) manager has modified the ER project breakdown structure (PBS). The consolidation of scope common to a facility in the same PBS will allow the program to plan and coordinate the scope more effectively. (complete)

DOE approval of PBS. The ER manager has worked closely with the DOE counterpart and has obtained approval. Customer satisfaction with the organization of project scope, schedule, and budget has been and continues to be very important to the development of the project breakdown structures. (complete)

Alignment of Closure Organization Breakdown Structure Around Projects. The ER manager has aligned the new ER organization breakdown structure (OBS) so that projects involving a common scope and facility have one project to carry out the work and a single project manager. (complete)

Designation of PBS Managers. The ER manager has selected the PBS managers based on project scope, schedule, budget, and facilities. This selection provides a common PBS manager leading the major facilities to a common end state. The common management, end state, and project establish the most effective process to bring the INEEL major facilities to the end of their useful life. (complete)

\subsubsection{Major FY 1998 Phase III Activities}

In FY 1998, the project team will produce the detailed INEEL End State Plan. The basis date for end-state planning is the year 2094; this date was selected based on the INEEL Long Range Plan date. During FY 1998, three major tasks will be completed: (1) finalizing the INEEL End State Plan; (2) developing a forecast and tracking system for the savings; and (3) implementing management of the end state plan. At the end of FY 1998, the reengineering of facility closure integration will be complete and the INEEL will have a process and plan for a cost-effective compliant closure.

INEEL End State Plan. The FY 1998 scope for the INEEL End State Plan includes four chapters about the INEEL and the six chapters that describe the end state of the major facilities. This plan is the tool that will allow the INEEL to close facilities in compliance and at the lowest cost possible.

Forecast and Tracking System for the Savings. A forecast and tracking system for additional savings will be developed in FY 1998 to proved detail information of the savings associated with the implementation of the INEEL End State Plan. This system will allow for the information in different type of cost estimates to be evaluated to determine the real savings from end state planning.

Management to the INEEL End State Plan. The key to the successful implementation of the INEEL End State Plan will be managing all INEEL closure work to the defined plan. Establishing management of the plan and control functions for changing the plan is part of the FY 1998 activities and will be an ongoing activity but will only be funded by the Compliance Reengineering Project in FY 1998.

Management of the plan and end states will allow for changes when required and the required coordination of these changes.

\subsubsection{Documentation of Results and Savings}

The status of the Phase III activities for Integration of Facility Closure improvements were reported to J. A. VanVliet by K. L. Falconer, the executive champion, by letter KLF-194-97. The letter defines the major activities and the economic impact of the changes. 


\subsubsection{Estimated Financial Benefit and Measurement Metrics}

The estimated financial benefits of integrating facility closures are as follows:

FY 1998

$\$ .61$ million
FY 1998-2002

$\$ 6.7$ million

Implementation details and metrics are provided in Table 4.7.8.

Table 4.7.8. Integration of facility closure implementation benefits and tracking.

Note: Assumes \$80/hour labor rate.

Implementation Benefits:

\begin{tabular}{|l|c|l|}
\hline \multicolumn{1}{|c|}{ Activity } & Implementation Date & \multicolumn{1}{|c|}{ Benefit Goal } \\
\hline Consolidation of organization & $9 / 30 / 97$ & $\begin{array}{l}\$ 600 \mathrm{~K} \\
(\$ 120 \mathrm{~K} / \text { year for 5 years })\end{array}$ \\
& $\begin{array}{l}\text { Will achieve additional cost } \\
\text { savings in dollars and in reduction } \\
\text { of rework in the out years. The } \\
\text { amount of savings is to be } \\
\text { developed as part of the FY 1998 } \\
\text { INEEL end state planning process. }\end{array}$ \\
\hline
\end{tabular}

Implementation Tracking:

\begin{tabular}{|l|l|l|l|l|}
\hline $\begin{array}{l}\text { Implementation Process } \\
\text { Performance Indicators }\end{array}$ & Metric & Baseline & Commitment & Data Source \\
\hline $\begin{array}{l}\text { Combine INEEL organizations for } \\
\text { D\&D, FDI, and other closure } \\
\begin{array}{l}\text { activities; to be managed by one } \\
\text { department manager }\end{array}\end{array}$ & $\begin{array}{l}\text { Eliminate } \\
\text { funding for } \\
\text { one manager }\end{array}$ & $\begin{array}{l}\text { ICPP D\&D } \\
\text { management } \\
\text { budget } \\
\text { reduced }\end{array}$ & 1,500 hours & $\begin{array}{l}\text { ICPP D\&D } \\
\text { EM-60 budget } \\
\text { management } \\
\text { charges }\end{array}$ \\
\hline
\end{tabular}

Implementation Benefits:

\begin{tabular}{|l|l|l|}
\hline \multicolumn{1}{|c|}{ Activity } & Implementation Date & \multicolumn{1}{c|}{ Benefit Goal } \\
\hline $\begin{array}{l}\text { Creation of end states integration, } \\
\text { redundant soil/waste repository }\end{array}$ & $\begin{array}{l}\text { Common soil disposal } \\
\text { option completed by } \\
2002\end{array}$ & $\begin{array}{l}\text { \$3,100 K } \\
\text { Will achieve additional cost } \\
\text { savings in dollars and in reduction } \\
\text { of rework in the out years. The } \\
\text { amount of savings is to be } \\
\text { developed as part of the FY 1998 } \\
\text { INEEL end state planning process. }\end{array}$ \\
\hline
\end{tabular}


Table 4.7.8. (continued).

Implementation Tracking:

\begin{tabular}{|l|l|l|l|l|}
\hline $\begin{array}{l}\text { Implementation Process } \\
\text { Performance Indicators }\end{array}$ & Metric & Baseline & Commitment & Data Source \\
\hline Reduce number of repositories & $\begin{array}{l}\text { Close } \\
\text { repositories }\end{array}$ & $\begin{array}{l}\text { Budgets } \\
\text { FY 1998 }\end{array}$ & $\$ .5 \mathrm{M}$ & $\begin{array}{l}\text { Closure work } \\
\text { packages that } \\
\text { fund } \\
\text { repositories in } \\
\text { the year of the } \\
\text { reduction }\end{array}$ \\
& FY 1999 \\
& FY 2000 & $\$ .1 .1 \mathrm{M}$ \\
FY 2001 & $\$ .5 \mathrm{M}$ & \\
& & FY 2002 & & \\
\hline
\end{tabular}

\subsubsection{Implementation Completion Date}

The completion date has changed from January 1, 1998 to September 30, 1998. This change was necessary to accommodate the scope addition of the ICPP pilot for the end state plan and the Level 3 activities (tracking and planning tables for buildings, structures, CERCLA sites, utilities, and infrastructure) from reengineering project recommendations.

\subsubsection{Major Changes Since Phase I Estimate}

The Phase I FY 1998 estimate of \$3.7 million decreased to \$0.12 million. The Phase IFY 1998-2002 estimate of $\$ 11.4$ million decreased to $\$ 3.1$ million. These decreases occurred because the closure activities of greatest potential benefit will occur after the FY 1998-2002 period. Savings, after that time, however, will be substantially more than the original $\$ 11.4$ million estimate. The major savings are projected for the out years (after FY 2002) and will be based on the schedule/escalation of facility closure. 


\subsection{LMITCO/Parsons Internal Document Review Process (\#8)}

\subsubsection{Purpose}

The purpose of the reengineering project for LMITCO/Parsons Environmental Restoration (ER) internal review process was to streamline the process to eliminate inefficiencies and redundancies.

\subsubsection{Scope}

The scope of the project was to examine the Parsons internal review process, the LMITCO ER internal/independent review process, and the facility review process to eliminate redundancies and to simplify, integrate, or streamline the process to eliminate inefficiencies.

\subsubsection{Major Phase II Activities}

To determine the as-is process, the project team for LMITCO/Parsons internal document reviews examined the following processes: Parsons internal reviews, LMITCO ER internal/independent reviews, and LMITCO ER facilities reviews. The team prepared an as-is document and flow process and validated the as-is process. The team consolidated the LMITCO/Parsons internal review process. They prepared a memorandum of understanding to include facilities in the internal review committee and revised the applicable procedures to reflect the consolidated process. As a followup to a murder board recommendation, a baseline change proposal (BCP) was issued to streamline the ER review process, while improving the quality of the documents through the implementation of a peer review team.

\subsubsection{As-Is/To-Be Analysis}

The results of the as-is/to-be analysis are shown in Table 4.8.4

Table 4.8.4. LMITCO/Parsons internal review components of change.

\begin{tabular}{|c|c|}
\hline As-Is & To-Be \\
\hline $\begin{array}{l}\text { Parsons, Environmental Restoration, facilities, } \\
\text { DOE, Environmental Protection Agency (EPA), and } \\
\text { Idaho Department of Health and Welfare (IDHW) } \\
\text { have separate review processes }\end{array}$ & \multirow{2}{*}{$\begin{array}{l}\text { Include Parsons and facilities on the internal review } \\
\text { committee, which will consolidate the process, } \\
\text { eliminate redundancies in disciplines, reduce review } \\
\text { cycles, implement a cross-organizational team } \\
\text { approach, standardize the review process across all } \\
\text { waste area groups (WAGs) and facilities, improve } \\
\text { communication, increase morale, and reduce costs }\end{array}$} \\
\hline $\begin{array}{l}\text { Redundancies and inefficiencies; processes that can } \\
\text { be simplified, integrated, or streamlined }\end{array}$ & \\
\hline
\end{tabular}

\subsubsection{Major FY 1997 Phase III Activities}

Improvement actions associated with this project were identified during the murder boards. A baseline change proposal (BCP) has been implemented, which resulted in cost savings through reduced review cycles while increasing the quality of documents through the use of a peer review team. The BCP documents the reallocation of $\$ 300 \mathrm{~K}$ per year to other needed scope. Cost savings are also being realized through consolidation of facility reviews with the new streamlined Independent Review Committee (IRC) process within Environmental Restoration. 


\subsubsection{Major FY 1998 Phase III Activities}

There will be no major activities, other than tracking of savings, which is covered as part of the Change Management project.

\subsubsection{Documentation of Results and Savings}

The status of the Phase III activities for LMITCO/Parsons Internal Document Review Process improvements were reported to J. A. VanVliet by K. L. Falconer, the executive champion, by letter KLF-194-97. The letter defines the major activities and the economic impact of the changes.

\subsubsection{Estimated Financial Benefit and Measurement Metrics}

The estimated financial benefits of the reengineered internal review process are as follows:

$\frac{\text { FY } 1998}{\$ .30 \text { million }} \quad \frac{\text { FY 1998-2002 }}{\$ 1.475 \text { million }}$

Implementation details and metrics are provided in Table 4.8.8.

Table 4.8.8. LMITCO/Parsons internal document review process implementation benefits and tracking.

Note: Assumes \$60/hour labor rate.

Implementation Benefits:

\begin{tabular}{|l|l|c|}
\hline \multicolumn{1}{|c|}{ Activity } & Implementation Date & Benefit Goal \\
\hline $\begin{array}{l}\text { Develop and implement a streamlined review } \\
\text { process for technical solutions }\end{array}$ & $7 / 8 / 97$ & $\$ 300 \mathrm{~K}$ annually \\
\hline
\end{tabular}

Implementation Tracking:

\begin{tabular}{|c|c|c|c|c|}
\hline $\begin{array}{l}\text { Implementation Process } \\
\text { Performance Indicators }\end{array}$ & Metric & Baseline & Commitment & Data Source \\
\hline $\begin{array}{l}\text { - Review of documents performed by } \\
\text { one hand-picked committee } \\
\text { represented by Lockheed, Parsons, } \\
\text { and facility (vs. three committees) } \\
\text { - Up to two facility people only, } \\
\text { represented on internal review } \\
\text { committee }\end{array}$ & $\begin{array}{l}\text { Total review } \\
\text { time per ER } \\
\text { document }\end{array}$ & TBD & 5,000 hours & $\begin{array}{l}\text { ERPC control } \\
\text { account }\end{array}$ \\
\hline
\end{tabular}

\subsubsection{Implementation Completion Date}

The LMITCO/Parsons internal review process was implemented July 8, 1997.

\subsubsection{Major Changes Since Phase I Estimate}

The Phase I FY 1998 estimate of $\$ 0.976$ million decreased to $\$ 0.30$ million. The Phase I FY 1998-2002 estimate of $\$ 3.9$ million decreased to $\$ 1.475$ million. The Phase I estimate assumed more time was spent in the reviews than was validated after closer examination. 


\subsection{LMITCO/Parsons Project Management Interface (\#20)}

\subsubsection{Purpose}

The purpose of the LMITCO/Parsons project management interface reengineering project was to streamline the project management interfaces, tools, and systems and to eliminate redundant procedures.

\subsubsection{Scope}

The scope of the project was to examine current project management interfaces, roles and responsibilities, acquisition of services, project management tools and systems (such as software and hardware), and procedures to eliminate inefficiencies and redundancies.

\subsubsection{Major Phase II Activities}

To determine the as-is process, project team examined the following items: current project management interfaces, roles and responsibilities, acquisition of services, tools and systems, and procedures. They completed a flow diagram of the as-is process showing the combined administrative and technical support of the DOE-ID, LMTTCO, and Parsons project management organizations. They validated the flow diagram and identified redundant roles. The team developed a to-be process that eliminated the inefficiencies and redundancies they found during the as-is analysis. The to-be process complies with all requirements. The team developed as-is and to-be process flow charts and an implementation plan to achieve the to-be process during Phase III.

\subsubsection{As-Is/To-Be Analysis}

The results of the as-is/to-be analysis are shown in Table 4.9.4

Table 4.9.4. LMITCO/Parsons project management interface components of change.

\begin{tabular}{l|l}
\hline \multicolumn{1}{c|}{ As-Is } & \multicolumn{1}{c}{ To-Be } \\
\hline $\begin{array}{l}\text { Duplicate positions, roles, and } \\
\text { responsibilities }\end{array}$ & $\begin{array}{l}\text { Establish a single line organizational structure including } \\
\text { roles and responsibilities, project control systems, acquisition } \\
\text { of services, project management tools (hardware, software), } \\
\text { matrix and support organizational interface requirements, } \\
\text { estimating, and internal review committee }\end{array}$ \\
\hline
\end{tabular}

\subsubsection{Major FY 1997 Phase III Activities}

A reengineered project staffing process has been implemented, which eliminates layered and redundant LMTCO/Parsons project management, resulting in annual savings of $\$ 984 \mathrm{~K}$. In addition, LMITCO and Parsons are now working to one technical/cost/schedule baseline. A more accurate accounting of Parsons' costs has also been instituted through real-tine data entry of labor charges instead of accruals, and Parsons' ability to use charge numbers within LMITCO's system. These improvements will result in an additional $\$ 1.25 \mathrm{M}$ in savings annually. 


\subsubsection{Major FY 1998 Phase III Activities}

There will be no major activities, other than tracking of savings, which is covered as part of the Change Management project.

\subsubsection{Documentation of Results and Savings}

The status of the Phase III activities for LMITCO/Parsons Project Management Interface improvements were reported to J. A. VanVliet by K. L. Falconer, the executive champion, by letter KLF-194-97. The letter defines the major activities and the economic impact of the changes.

\subsubsection{Estimated Financial Benefit and Measurement Metrics}

The estimated benefits of the reengineered LMITCO/Parsons project management interface are as follows:

FY 1998

$\$ 2.242$ million
FY 1998-2002

$\$ 11.21$ million

The reengineered LMITCO/Parsons project management interface will result in the following non-financial improvements: eliminates layered and redundant positions and administrative controls; allows for skill and expertise staffing of projects; improves skill mix; provides quicker access to resources; eliminates duplicate/parallel administrative controls; provides a standard mission, policy, plan, and implementing process; positions the LMITCO/Parsons ER team for global market competitiveness; reduces costs; improves communications with DOE; and standardizes baseline management.

Implementation details and metrics are provided in Table 4.9.8.

Table 4.9.8. LMITCO/Parsons project management interface implementation benefits and tracking.

Note: Assumes $\$ 140 /$ hour labor rate.

Implementation Benefits:

\begin{tabular}{|l|l|l|}
\hline \multicolumn{1}{|c|}{ Activity } & Implementation Date & \multicolumn{1}{c|}{ Benefit Goal } \\
\hline $\begin{array}{l}\text { Reengineer and implement a single line } \\
\text { organizational structure that eliminates } \\
\text { layered and redundant positions }\end{array}$ & $\bullet 9 / 30 / 98$ & $\begin{array}{l}\text { \$984 K annual savings, plus } \\
\text { skill and expertise staffing, frees } \\
\text { up resources, eliminates } \\
\text { duplicate administrative } \\
\text { controls, defines roles and } \\
\text { responsibilities. } \\
\$ 1,250 \mathrm{~K} \text { annually }\end{array}$ \\
$\begin{array}{l}\text { Reengineer the project control (cost } \\
\text { and schedule) interface to (1) create an } \\
\text { electronic link between the } \\
\begin{array}{l}\text { LMITCO/Parsons baselines, (2) recluce } \\
\text { information transfer time, and (3) } \\
\text { enhance the task agreement process } \\
\text { time }\end{array}\end{array}$ & $-9 / 30 / 98$ & \\
\hline
\end{tabular}


Table 4.9.8. (continued).

Implementation Tracking:

\begin{tabular}{|c|c|c|c|c|}
\hline $\begin{array}{l}\text { Implementation Process } \\
\text { Performance Indicators }\end{array}$ & Metric & Baseline & Commitment & Data Source \\
\hline $\begin{array}{l}\text { - One project manager per project } \\
\text { - Process for completing baseline } \\
\text { detail is followed } \\
\text { - Monthly status reporting } \\
\text { guidelines are followed by } \\
\text { LMITCO and Parsons } \\
\text { - Parsons timesheets entered into } \\
\text { CAPS daily }\end{array}$ & $\begin{array}{l}\text { Reduced FTE } \\
\text { time charged to } \\
\text { management } \\
\text { project }\end{array}$ & $\begin{array}{l}\text { Will be } \\
\text { developed in } \\
1998 \text { field } \\
\text { season by } 7 / 98\end{array}$ & 15,932 hours & $\begin{array}{l}\text { Printout of } \\
\text { people } \\
\text { charging } \\
\text { against a } \\
\text { project }\end{array}$ \\
\hline
\end{tabular}

Note: Costs associated with initial implementation tracking and followup will be funded through Change Management Governance.

\subsubsection{Implementation Completion Date}

The LMITCO/Parsons project management interface reengineering project was implemented September 30, 1997.

\subsubsection{Major Changes Since Phase I Estimate}

The Phase IFY 1998 estimate of $\$ 2.0$ million increased to $\$ 2.242$ million. The Phase I FY $1998-2002$ estimate of $\$ 8.0$ million increased to $\$ 11.21$ million. 


\subsection{LMITCO/Parsons Project File and Vendor Data Management Systems (\#21)}

\subsubsection{Purpose}

The purpose of the reengineering project was to streamline the LMITCO/Parsons project file and vendor data management systems and requirements.

\subsubsection{Scope}

The scope of the project was to examine current project file and vendor data management systems and requirements to eliminate inefficiencies and redundancies and to examine vendor data deliverables and LMITCO/Parsons project file management for cost-effective improvements.

\subsubsection{Major Phase II Activities}

To determine the as-is process, the project team prepared flow diagrams of LMITCO and Parsons' processes and validated them, examined current LMITCO/Parsons project file and vendor data management systems and requirements and identified inefficiencies and redundancies that can be eliminated, compared the INEEL construction project management vendor data system to the Environmental Restoration system and evaluated costs and potential long-term savings, and evaluated vendor data deliverables and LMITCO/Parsons project file management to identify cost-effective improvements. They examined contractual and proprietary issues, identified safety, health, and quality restraints and impacts, examined liability issues, and reviewed lessons learned form the current LMITCO Construction Project Management Vendor Data System. The team designed cost-effective improvements and eliminated inefficiencies and redundancies they found during the as-is analysis. They streamlined and consolidated the LMITCO/Parsons project file and vendor data management systems and requirements while continuing to comply with all requirements. The team prepared a flow diagram of the to-be process and validated it. They revised the applicable procedures to incorporate the consolidated process and prepared a DACI (doer, accountable, consult, inform) chart and an implementation plan and strategy.

\subsubsection{As-Is/To-Be Analysis}

The results of the as-is/to-be analysis are shown in Table 4.10.4

Table 410.4. LMITCO/Parsons project file and vendor data management systems components of change.

\begin{tabular}{l|l}
\hline \multicolumn{1}{c|}{ As-Is } & \multicolumn{1}{c}{ To-Be } \\
\hline Duplicate organization, process & $\begin{array}{l}\text { Establish one centralized ER process, procedure, and } \\
\text { processing center to administer vendor data }\end{array}$ \\
\hline Duplicate procedure, process, processing & $\begin{array}{l}\text { Establish one ER document control procedure, process, and } \\
\text { processing center }\end{array}$ \\
\hline Excessive volume & Establish one ER library \\
\cline { 2 - 2 } & $\begin{array}{l}\text { Establish one ER optical imaging system/administrative record } \\
\text { document control (OIS/ARDC) }\end{array}$ \\
\hline
\end{tabular}




\subsubsection{Major FY 1997 Phase III Activities}

Four improvement areas will result in a total of $\$ 182 \mathrm{~K}$ in savings annually. Specific changes implemented include the consolidation of LMTTCO and Parsons document control and optical scanning functions, as well as their libraries. In addition, the ER vendor data process has been streamlined, which dramatically reduces contract approval time and simplifies LMITCO vendor data management with Parsons.

\subsubsection{Major FY 1998 Phase III Activities}

There will be no major activities, other than tracking of savings, which is covered as part of the Change Management project.

\subsubsection{Documentation of Results and Savings}

The status of the Phase III activities for LMITCO/Parsons Project File and Vendor Data Management Systems improvements were reported to J. A. VanVliet by K. L. Falconer, the executive champion, by letter KLF-194-97. The letter defines the major activities and the economic impact of the changes.

\subsubsection{Estimated Financial Benefitt and Measurement Metrics}

The estimated financial benefits from the reengineered LMITCO/Parsons project file and vendor data management systems are as follows:
FY 1998
FY 1998-2002
$\$ .183$ million
$\$ .914$ million

The non-financial benefits of this project include reduced number of procedures, space requirements for filing, and distribution, quicker accesis to files and information, and better communication and record accessibility. Implementation details and metrics are provided in Table 4.10.8.

Table 4.10.8. LMITCO/Parsons project file and vendor data management systems implementation benefits and tracking.

Note: Assumes $\$ 72 /$ hour labor rates.

Implementation Benefits:

\begin{tabular}{|c|c|c|}
\hline Activity & Implementation Date & Benefit Goal \\
\hline - Consolidate LMITCO/Parsons document control & Completed & $\$ 28.4 \mathrm{~K}$ annually \\
\hline - Consolidate LMITCO/Parsons library & Completed & $\$ 11 \mathrm{~K}$ annually \\
\hline $\begin{array}{l}\text { - Reengineer and consolidate LMITCO/Parsons optical } \\
\text { imaging scanning (OIS) process }\end{array}$ & $5 / 31 / 97$ & $\$ 98 \mathrm{~K}$ annually \\
\hline $\begin{array}{l}\text { - Develop and implement a reengineered vendor data } \\
\text { process }\end{array}$ & $5 / 31 / 97$ & $\$ 45 \mathrm{~K}$ annually \\
\hline
\end{tabular}


Table 4.10.8. (continued).

Implementation Tracking:

\begin{tabular}{|c|c|c|c|c|}
\hline $\begin{array}{l}\text { Implementation Process } \\
\text { Performance Indicators }\end{array}$ & Metric & Baseline & Commitment & Data Source \\
\hline $\begin{array}{l}\text { Document control performed by } \\
\text { LMTTCO only } \\
\text { LMITCO/Parsons library remains } \\
\text { consolidated } \\
\text { - Optical image scanning of } \\
\text { LMTTCO/Parsons documents is on } \\
\text { schedule } \\
\text { - Vendor data procedure is being } \\
\text { followed }\end{array}$ & $\begin{array}{l}\text { Reduced FTE } \\
\text { time to process } \\
\text { document } \\
\text { handling }\end{array}$ & May 1997 & 2,545 hours & $\begin{array}{l}\text { Timesheets } \\
\text { for Parsons } \\
\text { document } \\
\text { control } \\
\text { personnel }\end{array}$ \\
\hline
\end{tabular}

\subsubsection{Implementation Completion Date}

The reengineered LMITCO/Parsons project file and vendor data management systems was implemented September 30, 1997.

\subsubsection{Major Changes Since Phase I Estimate}

The Phase I FY 1998 estimate of $\$ .50$ million decreased to $\$ .183$ million. The Phase IFY 1998-2002 estimate of $\$ 2.0$ million decreased to $\$ .914$ million. 


\subsection{Project Management System (\#22, 23, 24 19b)}

\subsubsection{Purpose}

The purpose of the project management system reengineering project is to develop a standard approach to project management, planning, estimating, and reporting for the EM program, to develop a project manager job family, and to establish an EM standard project management software.

\subsubsection{Scope}

Developing standard project management for EM projects includes defining work package/control account development, baseline control process, change control process, cost estimate basis requirements, life-cycle planning, standardized documentation, training requirements for work package/control account managers, and consistent reporting and roll-ups. The standardized project management process will be implemented by all projects in EM.

Developing a project management job family includes establishing a project manager advisory board, developing project manager standards and criteria, identifying project manager training and development, and assigning project manager roles and responsibilities.

Establishing standard project management software includes identifying functional requirements, developing an evaluation plan and evaluation criteria for measuring potential software, selecting potential vendor products, evaluating products, and selecting software.

\subsubsection{Major Phase II Activities}

The project team determined the as-is process by interviewing representatives from Waste Operations, Nuclear Operations, Environmental Restoration, and other EM organizations and by coordinating with other initiatives, such as the projectization team, the procedures consolidation integrated product team, and the compliance reengineering cost-estimating team. They reviewed project management requirements for project scoping, work package/control account development, baseline control, change control, performance measurement, risk management, cost estimating, work authorization, and reporting. The team conducted a risk management assessment and a cost-estimating assessment and documented the as-is process, issues and solutions, and approaches to issues. The Phase II team developed an implementation plan (INEEL/INT-97-00444, May 1997) that established four recommendations:

- Standardize the EM program project management processes

- Establish an INEEL EM Program life-cycle baseline

- Establish an EM program office

- Replace the current LMITCO legacy business management system.

The project management job family team developed standards and criteria for the program and project manager job family, suggested potential training for the project managers, and determined appropriate roles and responsibilities for the PM job family. 
To determine which project management software to implement, the team established functional requirements for project management software, identified mandatory requirements and assigned weights to requirements, developed an evaluation plan and evaluation criteria against which potential project management software would be measured, prepared benchmarks and identified reviewers, identified potential project management software to evaluate, and evaluated project management software.

\subsubsection{As-Is/To-Be Analysis}

Table 4.12.4. Project management systems components of change.

\begin{tabular}{l|l}
\hline \multicolumn{1}{c|}{ As-Is } & \multicolumn{1}{c}{ To-Be } \\
More than one EM Program project management & $\begin{array}{l}\text { Standardize all EM Program project management } \\
\text { processes }\end{array}$ \\
\hline No EM Program life-cycle baseline & Establish an INEEL EM Program life-cycle baseline \\
\hline No EM Program Office & Establish an EM Program Office \\
\hline $\begin{array}{l}\text { Existing legacy business management system } \\
\text { ineffective }\end{array}$ & Replace legacy business management system \\
\hline Many different reporting systems and reports in EM & Standardize reporting \\
\hline Inconsistent project cost estimating & Standardize cost estimating \\
\hline Inconsistent planning documentation & $\begin{array}{l}\text { Standardize control accounts and work package } \\
\text { documentation }\end{array}$ \\
\hline Many different change control boards and processes & Implement one change control process for EM \\
\hline $\begin{array}{l}\text { Company procedures not implemented consistently } \\
\text { across EM }\end{array}$ & Implement company procedures \\
\hline No project management roles and responsibilities & $\begin{array}{l}\text { Establish specific project manager roles and } \\
\text { responsibilities }\end{array}$ \\
\hline $\begin{array}{l}\text { Project manager job title applied with no specific } \\
\text { criteria }\end{array}$ & $\begin{array}{l}\text { Establish project manager advisory board to } \\
\text { establish and maintain criteria for project managers }\end{array}$ \\
\hline No project management career path & Establish project management job family \\
\hline $\begin{array}{l}\text { Several project management software packages are } \\
\text { used in EM }\end{array}$ & $\begin{array}{l}\text { Implement one project management software as an } \\
\text { EM standard }\end{array}$ \\
\hline
\end{tabular}

\subsubsection{Major FY 1997 Phase III Activities}

The Phase III reengineering project team, named the Project Management Systems Reengineering (PMSR) team, made significant advancernents towards improving and standardizing the EM project management processes, using a systems engineering approach and an emphasis on team work, user involvement, and communication. The PMSR Phase III Requirements Document was approved by the steering board and major accomplishments were completed in four specific projects: PM system reengineering, PM scheduling software, F'M job family, and legacy business system.

Project Management System Reengineering (standarization of project management process, lifecycle baseline, and EM program office). The EM 21-step project management process and the management of projects process have been reviewed by users and approved by the steering board; the inputs and outputs for the process are being defined and standardized; and the PM manual to explain and 
implement the process is being developed. The functions and responsibilities of the EM program office have been established, and standard processes for work authorization, reporting and performance measures, change control, prioritization, and data warehousing are being established and incorporated into the PM manual. The Davis \& Dean Project Management Simulation training was piloted and approved by the steering board to be used as part of the site-wide PM training.

PM Job Family. The team defined responsibilities and minimum requirements for project and program managers, obtained approvals, and submitted the project management job family for implementation by Human Resources.

Project Management Scheduling Software. After vendor demonstrations and field-testing were completed, Project Scheduler 7 (P/S 7) was selected as the LMITCO standard, and a contract was awarded for developing the interface between the P/S 7 and the current Dekker-Tracker program.

Legacy Business Management Systems. The replacement of the Legacy Business Management System will be separated in FY 1998 because of the significance and magnitude of the project.

\subsubsection{Major FY 1998 Phase III Activities}

- Continue the following FY 1997 Project Management System Reengineering activities: complete EM project management PM processes and procedures; develop standard cost-estimating practices; develop and implement life-cycle planning capability; develop resource management support capability.

- Complete the EM Project Management manual: define the project scoping procedure, uniform milestone criteria, and other manual sections; revise company management control procedures (MCPs) as necessary; finalize and distribute the PM manual to appropriate EM personnel; complete any FY 1997 activities (change control, reporting, prioritization, work authorization, project closeout, project management control data, etc.).

- Complete the Management of Projects manual: define EM program office function and other EM PM manual sections; finalize Management of Projects manual and turn over the EM program office for use and maintenance; distribute the manual.

- Implement the standard PM software in EM: provide software training for EM programs; complete utility upgrades; implement the PM software (P/S 7 and DT Windows) in the EM programs.

- Institutionalize the project management system: communicate team activities with the company, users, key individuals, and the steering board; provide training of the PM process.

\subsubsection{Documentation of Results and Savings}

The status of the Phase III activities for Project Management System Reengineering improvements were reported to J. A. VanVliet by S. A. Scobby, the executive champion, by letter SAS-117-97. The letter defines the major activities and the economic impact of the changes. 


\subsubsection{Estimated Financial Benefit and Measurement Metrics}

The estimated financial benefits of the reengineered project management systems are as follows: FY 1998

FY 1998-2002

Standardize all EM Program project management processes

$\$ 13.4 \mathrm{M}$

Establish an INEEL EM Program life-cycle baseline

$\$ 19.4 \mathrm{M}$

Establish an EM Program Office

$\$ 4.7 \mathrm{M}$

Project management job family

One standard project management software

$\$ 5.6 \mathrm{M}$

Replace Legacy Business Management System

$\$ 3.9 \mathrm{M}$

Total

$\$ 18.7 \mathrm{M}^{*}$

$\$ 61.8 \mathrm{M}$

* Not included in total; legacy business system replacement was moved to a separate company initiative.

The non-financial benefits of implementing one EM project management system are: elimination of redundant and unnecessary requirements and activities; increased credibility of the EM Program; reduced audit findings and eased audit process; mobility of project management personnel across EM; building and maintaining core competency of EM Program; fulfilling proposal promise to bring effective project management techniques to INEEL; allowing program level analysis; and providing consistent and credible information to management. Implementation details and metrics are provided in Table 4.12.8.

Table 4.12.8. Project Management System Reengineering implementation benefits and tracking.

Note: Assumes \$53/hour labor rate.

\section{Standardizing of Project Management Processes}

Implementation Benefits:

\begin{tabular}{|c|c|c|}
\hline Activity & Implementation Date & Benefit Goal \\
\hline Standardizing project management processes & FY 1998-1999 & \$13.4 million \\
\hline
\end{tabular}

Implementation Tracking:

\begin{tabular}{|c|c|c|c|c|}
\hline $\begin{array}{l}\text { Implementation Process } \\
\text { Performance Indicators }\end{array}$ & Metric & Baseline & Commitment & Data Source \\
\hline $\begin{array}{l}\text { Marked improvements } \\
\text { in project planning, } \\
\text { project execution, and } \\
\text { performance reporting } \\
\text { - Marked reduction in un- } \\
\text { compensated overtime } \\
\text { - Marked improvement in } \\
\text { LMITCO/DOE-ID } \\
\text { project management } \\
\text { capability, competence, } \\
\text { communication and } \\
\text { interface }\end{array}$ & $\begin{array}{l}\text { - Baseline change } \\
\text { proposal (BCP) } \\
\text { documenting savings } \\
\text { - Funds change } \\
\text { notification (FCN) } \\
\text { documenting savings } \\
\text { - Completed work in } \\
\text { accordance with } \\
\text { validated scope, } \\
\text { schedule and budget } \\
\text { Approved DOE-ID } \\
\text { cost savings/ } \\
\text { productivity } \\
\text { improvement form }\end{array}$ & $\begin{array}{l}\text { Reduction of } \\
\text { approximately } \\
203,800 \text { hours } \\
\text { in planned } \\
\text { labor in FY } \\
1998 \text { through } \\
\text { FY } 2002\end{array}$ & \begin{tabular}{|l|} 
Resources \\
reduced by \\
approximately \\
22 FTEs over \\
the period FY \\
1998 through \\
FY 2002
\end{tabular} & $\begin{array}{l}\text { - Individual } \\
\text { project } \\
\text { performance } \\
\text { baseline } \\
\text { information } \\
\text { Documented } \\
\text { cost savings/ } \\
\text { productivity } \\
\text { improvements } \\
\text { (included in } \\
\text { LMTTCO PEP } \\
\text { self- } \\
\text { assessment } \\
\text { document) }\end{array}$ \\
\hline
\end{tabular}


Table 4.12.8. (continued).

\section{Life Cycle Planning for EM Program}

Implementation Benefits:

\begin{tabular}{|c|c|c|}
\hline Activity & Implementation Date & Benefit Goal \\
\hline Life cycle planning for EM Program & FY 1998-1999 & \$19.4 million \\
\hline
\end{tabular}

Implementation Tracking:

\begin{tabular}{|c|c|c|c|c|}
\hline $\begin{array}{l}\text { Implementation Process } \\
\text { Performance Indicators }\end{array}$ & Metric & Baseline & Commitment & Data Source \\
\hline $\begin{array}{l}\text { Elimination of annual } \\
\text { project replanning } \\
\text { process } \\
\text { - Marked improvements } \\
\text { in project planning, } \\
\text { project execution and } \\
\text { performance reporting } \\
\text { - Marked reduction in } \\
\text { un-compensated } \\
\text { overtime }\end{array}$ & $\begin{array}{l}\text { - Baseline change } \\
\text { proposal (BCP) } \\
\text { documenting savings } \\
\text { - Funds change } \\
\text { notification (FCN) } \\
\text { documenting savings } \\
\text { - DOE-ID cost } \\
\text { savings/ productivity } \\
\text { improvement form } \\
\text { - Completed work in } \\
\text { accordance with } \\
\text { validated scope, } \\
\text { schedule, and budget }\end{array}$ & $\begin{array}{l}\text { Reduction of } \\
\text { approximately } \\
294,200 \text { hours } \\
\text { in planned } \\
\text { labor over the } \\
\text { period FY } \\
1998 \text { through } \\
\text { FY } 2002\end{array}$ & $\begin{array}{l}\text { Resources } \\
\text { reduced by } \\
\text { approximately } \\
24 \text { FTEs over } \\
\text { the period FY } \\
1998 \text { through } \\
\text { FY } 2002\end{array}$ & $\begin{array}{l}\text { - Individual } \\
\text { project } \\
\text { performance } \\
\text { baseline } \\
\text { information } \\
\text { - Documented } \\
\text { cost savings/ } \\
\text { productivity } \\
\text { improvements } \\
\text { (included in } \\
\text { LMITCO PEP } \\
\text { self-assessment } \\
\text { document) }\end{array}$ \\
\hline
\end{tabular}

\section{EM Program Office}

Implementation Benefits:

\begin{tabular}{|c|c|c|}
\hline Activity & Implementation Date & Benefit Goal \\
\hline EM Program Office & FY 1998-1999 & $\$ 4.7$ million \\
\hline
\end{tabular}

Implementation Tracking:

\begin{tabular}{|c|c|c|c|c|}
\hline $\begin{array}{l}\text { Implementation Process } \\
\text { Performance Indicators }\end{array}$ & Metric & Baseline & Commitment & Data Source \\
\hline $\begin{array}{l}\text { Marked improvements in } \\
\text { project planning, project } \\
\text { execution and } \\
\text { performance reporting } \\
\text { - Marked reduction in un- } \\
\text { compensated overtime } \\
\text { - Marked improvement in } \\
\text { LMITCO/DOE-ID } \\
\text { project management } \\
\text { capability, competence, } \\
\text { communication and } \\
\text { interface }\end{array}$ & $\begin{array}{l}\text { - Increased response } \\
\text { time to DOE-ID and } \\
\text { DOE-HQ inquiries } \\
\text { - Increased integrity/ } \\
\text { credibility of program } \\
\text { information } \\
\text { - Reduced project } \\
\text { management costs as a } \\
\text { percentage of total } \\
\text { project costs. } \\
\text { - Completed work in } \\
\text { accordance with } \\
\text { validated scope, } \\
\text { schedule and budget }\end{array}$ & $\begin{array}{l}\text { Reduction of } \\
\text { approximatel } \\
\text { y } 71,300 \\
\text { hours in } \\
\text { planned } \\
\text { labor over } \\
\text { the period } \\
\text { FY } 1998 \\
\text { through FY } \\
2002\end{array}$ & $\begin{array}{l}\text { Resources } \\
\text { reduced by } \\
\text { approximately } \\
12 \text { FTEs over } \\
\text { the period FY } \\
1998 \text { through } \\
\text { FY } 2002\end{array}$ & $\begin{array}{l}\text { - Individual } \\
\text { project } \\
\text { performance } \\
\text { baseline } \\
\text { information } \\
\text { - Documented } \\
\text { cost savings/ } \\
\text { productivity } \\
\text { improvements } \\
\text { (included in } \\
\text { LMITCO PEP } \\
\text { self- } \\
\text { assessment } \\
\text { document) }\end{array}$ \\
\hline
\end{tabular}


Table 4.12.8. (continued).

Project Management Software Change

Implementation Benefits:

\begin{tabular}{|c|c|c|}
\hline Activity & Implementation Date & Benefit Goal \\
\hline Project management software change & FY 1998-1999 & $\$ 5.6$ million \\
\hline
\end{tabular}

Implementation Tracking:

\begin{tabular}{|c|c|c|c|c|}
\hline $\begin{array}{l}\text { Implementation Process } \\
\text { Performance Indicators }\end{array}$ & Metric & Baseline & Commitment & Data Source \\
\hline $\begin{array}{l}\text { - Increased understanding and } \\
\text { use of scheduling and } \\
\text { performance concepts } \\
\text { - Marked improvements in } \\
\text { project planning, project } \\
\text { execution and performance } \\
\text { reporting } \\
\text { - Marked reduction in un- } \\
\text { compensated overtime } \\
\text { - Marked improvement in } \\
\text { LMITCO/DOE-ID project } \\
\text { management capability, } \\
\text { competence, communication } \\
\text { and interface }\end{array}$ & $\begin{array}{l}\text { - Reduced } \\
\text { dependence on } \\
\text { Project Control } \\
\text { representatives to } \\
\text { provide scheduling } \\
\text { and baseline } \\
\text { support } \\
\text { - Increased visibility } \\
\text { of project } \\
\text { schedules }\end{array}$ & $\begin{array}{l}\text { Reduction of } \\
\text { approximately } \\
85,000 \text { hours } \\
\text { in planned } \\
\text { labor over the } \\
\text { period FY } \\
1998 \text { through } \\
\text { FY } 2002\end{array}$ & $\begin{array}{l}\text { Resources } \\
\text { reduced by } \\
\text { approximately } \\
\text { five FTEs over } \\
\text { the period FY } \\
1998 \text { through } \\
\text { FY } 2002\end{array}$ & $\begin{array}{l}\text { - Individual } \\
\text { project } \\
\text { performance } \\
\text { baseline } \\
\text { information } \\
\text { - Program } \\
\text { Control } \\
\text { staffing } \\
\text { information }\end{array}$ \\
\hline
\end{tabular}

\section{Legacy Business Management System Replacement}

Implementation Benefits:

\begin{tabular}{|l|c|c|}
\hline \multicolumn{1}{|c|}{ Activity } & Implementation Date & Benefit Goal \\
\hline $\begin{array}{l}\text { Legacy Business Management System } \\
\text { replacement }\end{array}$ & FY 1998-1999 & \$18.7 million \\
\hline
\end{tabular}

The legacy business management system replacement activity has moved from the project management stream to a separate company initiative. Savings previously associated with this activity are no longer included in this stream.

\subsubsection{Implementation Completion Date}

A standardized project management process, life-cycle baseline, and EM Program Office will be implemented in April 1998. 


\subsubsection{Major Changes Since Phase I Estimate}

Phase I projects number 22 (Budgeting), number 23 (Data and Information), number 24 (Performance Measures), and number $19 \mathrm{~b}$ (Cost Engineering) were determined to be only band-aids for the more comprehensive project management issues. As a result, the scope was significantly changed. Therefore, the shorter term (1998) benefit decreased from $\$ 12.7$ million to $\$ 3.9$ million, but the longer term (1998-2002) benefit increased from $\$ 33.2$ million to $\$ 43.1$ million.

During Phase III, it was determined that the legacy business management systems should be managed as a separate company initiative due to the complexity, magnitude, and impact of the project. Additionally, it was determined during Phase III that further analysis of the as-is/to-be models developed in Phase II needed to be completed before implementation of a standard PM process could be recommended and detailed. 
Table 5-1. FY 1998 compliance reengineering potential and selected projects.

(Potential reengineering projects are listed below. The projects approved by the Compliance Reengineering Steering Board for FY 1998 Phase III are shaded.)

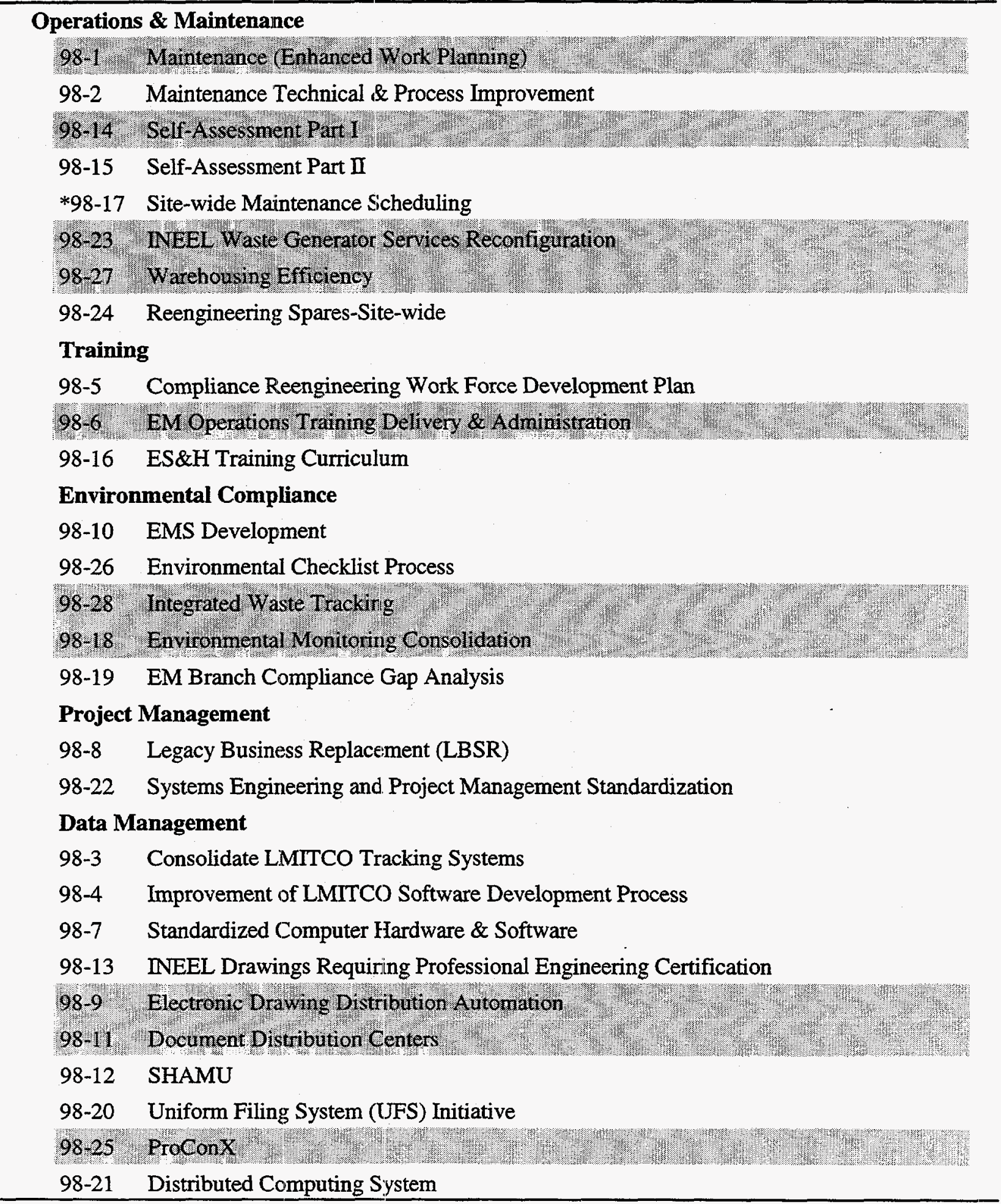


Table 5-2. Compliance reengineering projects selected for FY 1998.

Enhanced Work Planning (98-1)

\section{Purpose:}

The Enhanced Work Planning project will evaluate and improve the site work management programs for identifying, planning, approving, controlling, and executing work to improve efficiency, productivity, safety, and environmental compliance.

\section{Scope:}

Work management programs will be changed so that work is performed more effectively and safely, requiring less time and cost. Specific activities include (1) standardizing and streamlining the approval process for work through the application of a graded approach, (2) increasing efficiency by using a common standardized work package format and common work control procedures, (3) streamlining training for maintenance and work control personnel, (4) reducing the number of procedures requiring document control, and (5) improving safety with standardized hazard identification and mitigation.

\section{Reengineering Benefit/Cost:}

FY 1999-2002 benefit: $\$ 5.0$ million $\quad$ FY 1998 cost: $\$ .7$ million

Projected Implementation Date: September 1998

EM Operations Training Delivery and Administration (98-6)

\section{Purpose:}

The EM Operations Training Delivery and Administration project will implement an information and training delivery system that will be accessible and useable by all EM employees in order to improve the efficiency of the training administration and personnel qualification process.

\section{Scope:}

The information and training delivery system netRESULTS will be implemented for all EM programs and will be available for other operations. This system will provide access to qualification status information for operations and crafts personnel, desktop delivery of computer and network training, and registration and scheduling for training courses. Downloadable qualification standards and checklists will include a central repository of standards.

\section{Reengineering Benefit/Cost:}

FY 1999-2002 benefit: $\$ 9.9$ million FY 1998 cost: $\$ .3$ million

Projected Implementation Date: September 1998 
Table 5-2. (continued)

Electronic Drawing Distribution Automation (98-9)

Purpose:

The Electronic Drawing Distribution Automation project will reduce the turnaround time for access to new or revised drawings and to reduce the costs for releasing, printing, and controlling drawings.

\section{Scope:}

By enhancing the Electronic Document Management (EDM) imaging system, all EM drawings will be electronically imaged and made available to customers at their personal computers or common-use work stations and the drawing release cycle (currently 2 to 4 weeks) can be reduced to approximately 24 hours.

\section{Reengineering Benefit/Cost:}

FY 1999-2002 benefit: \$1.6 million FY 1998 cost: $\$ .3$ million

Projected Implementation Date: September 1998

\section{Document Distribution Centers (98-11)}

\section{Purpose:}

The Document Distribution Centers project will establish document libraries for personnel access to company-wide manuals in order to reduce the time and costs involved with document issue and control (paper copies).

\section{Scope:}

Approximately 15 document distribution centers will be established throughout the site to store complete sets (paper copies) of the company-wide manuals, which will be available 24 hours a day. The company standard for access to the documents will be provided by computer work stations to access the documents on-line. Paper distribution of these documents beyond the distribution centers will be eliminated. Implementing this project includes providing for training for personnel access to documents and performing an engineering analysis to determine where distribution centers will be necessary and what costs will be involved.

\section{Reengineering Benefit/Cost:}

FY 1999-2002 benefit: \$4.3 million FY 1998 cost: $\$ .2$ million

Projected Implementation Date: September 1998 
Table 5-2. (continued)

Environmental Monitoring Consolidation (98-18)

Purpose:

The Environmental Monitoring Consolidation project will establish a site-wide environmental monitoring program to integrate the monitoring and increase efficiency.

\section{Scope:}

The site-wide environmental monitoring program will integrate monitoring schedules and reduce the number of analytes sampled to only those that are required by permits or CERCLA agreements. An evaluation of methods for more efficient use of resources and equipment and improved tracking and reporting will also be performed.

\section{Reengineering Benefit/Cost:}

FY 1999-2002 benefit: \$1.5 million FY 1998 cost: $\$ .1$ million

Projected Implementation Date: third quarter, FY 1998

\section{INEEL Waste Generator Services Reconfiguration (98-23)}

\section{Purpose:}

The INEEL Waste Generator Services Reconfiguration project will consolidate the LMITCO waste generators services functions into a centralized organization of waste management professionals optimizing resources, improving efficiencies, minimizing waste rejection rates, improving oversight and customer relationships, and ensuring compliance.

\section{Scope:}

The consolidated waste management functions (information management systems for waste, RRWAC compliance, waste characterization and certification, packaging and transportation, waste forecasts, up-front generation approval, and temporary storage) will provide a single point of responsibility and remove those issues from facility operations.

\section{Reengineering Benefit/Cost:}

FY 1999-2002 benefit: $\$ 3.0$ million $\quad$ FY 1998 cost: $\$ .2$ million

Projected Implementation Date: third quarter, FY 1998 
Table 5-2. (continued)

Self-Assessment Pilot (98-14)

\section{Purpose:}

The Self-Assessment Pilot project will develop self-assessment processes and procedures to improve operational safety, compliance to environmental and operational requirements, efficiency of operations, and employee involvement in work processes. The self-assessment process will help sustain improvements made through the site-wide improvement programs currently underway.

\section{Scope:}

The process developed for the pilot will involve a cross-functional team representing the major INEEL operations and maintenance areas, and will be piloted at RWMC for 6 months to identify measures and enhancements. Lessons learned will be incorporated following the pilot.

\section{Reengineering Benefit/Cost:}

FY 1999-2002 benefit: $0 \quad$ FY 1998 cost: \$.06 million

Projected Implementation Date: April 1998

ProConX Procedure Compliance Update (98-25)

\section{Purpose:}

The ProConX Procedure Compliance Update project will reduce project management planning costs and provide an automated expert system (Project Control Expert system, ProConX) that institutionalizes a consistent company approach to project management by reinforcing Project Management Institute (PMI) principles, integration of LMITCO's MCPs, and maintenance of regulatory compliance.

\section{Scope:}

Improvements will include establishing a consistent company-wide methodology for project management compliance using an automated expert system to establish project criteria, maintain compliance with applicable procedures, and electronically store an audit trail.

\section{Reengineering Benefit/Cost:}

FY 1999-2002 benefit: \$1.4 million FY 1998 cost: $\$ .2$ million

Projected Implementation Date: October 1, 1998 
Table 5-2. (continued)

Integrated Waste Tracking (98-28)

Purpose:

The Integrated Waste Tracking project will maintain required waste characterization, generation, treatment, storage, and disposal information, provide system ownership by operations personnel, satisfy facility owners' fundamental operational needs, and use client/server and network technology to overcome limitations.

\section{Scope:}

Improvements will include the development and implementation of a site-wide system for facility inventory control, cost tracking for waste shipment, processing, and disposal, and reporting. Activities will include waste inventory assessment, container identification and coding, system deployment, facility-specific modifications, and archival of legacy database systems.

Reengineering Benefit/Cost:

FY 1999-2002 benefit: \$6.6 million FY 1998 cost \$.8 million

Projected Implementation Date: September, 1998

Systems Engineering Support (98-22)

Purpose:

The Systems Engineering Support project will improve project management documentation and training related to systems engineering.

\section{Scope:}

Improvements will include developing documentation detailing the steps necessary to produce required systems engineering documents and providing training materials for project management training related to systems engineering processes and tools.

\section{Reengineering Benefit/Cost:}

FY 1999-2002 benefit: $0 \quad$ FY 1998 cost: $\$ .06$ million

Note: Benefits are included with project management systems reengineering benefits.

Projected Implementation Date: April 1998 
Table 5-2. (continued)

Material Availability/Warehousing (98-27)

\section{Purpose:}

The Material Availability/Warehousing project will increase operations, maintenance, and research productivity and reduce material costs.

\section{Scope:}

Improvements will include the development and implementation of operational supportability analysis (quantitative technical analysis methods to determine material support requirements for EM operational systems), stocked material disposal (a unique process to dispose of excess stocked material inventory assets), and supply chain management (material supply methods that reduce material costs). The implementation of these key actions is interrelated; each item leverages information from OSA (operational supportability analysis).

\section{Reengineering Benefit/Cost:}

FY 1999-2002 benefit: \$.9 million $\quad$ FY 1998 cost: \$.3 million

Projected Implementation Date: September 1998 


\section{CRITICAL SUCCESS FACTORS}

In order to successfully implement transformational change, the INEEL must address and overcome the obstacles to change. The Compliance Reengineering Project identified seven critical success factors necessary to achieve implementation. Project personnel are continuing to work with senior LMITCO management through the Lockheed Quality Steering Team (LQST) and with DOE-ID management to implement these factors. The matrix in Table 6-1 shows how these factors are necessary for successful implementation of the specific improvement projects and therefore for achieving the savings resulting from the improvements. The numbered critical success factors in the table correspond to the numbered critical success factors in the following subsections.

\subsection{Mind Set}

1. LMITCO is the supplier; DOE is the customer.

2. Value revolves around successful project completion, not effort.

3. Performance measures drive the business; budgets do not.

4. Each person has personal accountability for his or her own safety and the safety of others.

5. Everyone wins when well-defined objectives are met.

6. Drive decision-making to the lowest practical level.

7. Correct and appropriate training is an investment, not an expense.

8. Functional managers must have funds for training personnel.

9 Functional managers must maintain core capabilities.

10. Each person must be willing to accept personal accountability

11. Continuous improvement is a necessity.

\subsection{Job Security}

1. There will be substantial cross-functional training.

2. Performance will replace entitlement.

3. Employees will share responsibility for skills development.

4. An effective process for redeployment of people is necessary.

5. Enhanced skills assessment and frequent performance evaluations will be the norm.

6. There will be a bigger penalty for not trying, rather than trying and failing.

\subsection{Power and Influence}

1. Resource and project management authority will replace functional line and territorial authority.

2. Power and influence will be created by project management successes.

3 Rewards will be based on achievement.

\subsection{Compliance}

1. Focus on applying personal safety first, then compliance.

2. Provide streamlined occurrence reporting. 
3. Define and utilize graded approach.

4. Enforce non-negotiables.

\subsection{Skills, Information Systems, Processes and Procedures}

1. Provide integrated program and project management systems.

2. Replace most legacy systems.

3. Provide master resource scheduling.

4. Define core project management standards.

5. Develop more efficient training delivery techniques.

\subsection{Products and Requirements}

1. Produce specific products that meet specific requirements.

2. Be responsive to changes in requirements.

3. Evaluate effect of process changes on ability to still meet requirements.

4. All activities will be tied to the successful delivery of INEEL core products.

5. Support functions will be performed only as their value-added to INEEL core products is commensurate with their cost.

\subsection{Work Organization}

1. Work will be consolidated into non-segmented work breakdown structures while implementing the matrix system.

2. Consolidation of organizations is required to obtain projected cost savings. 


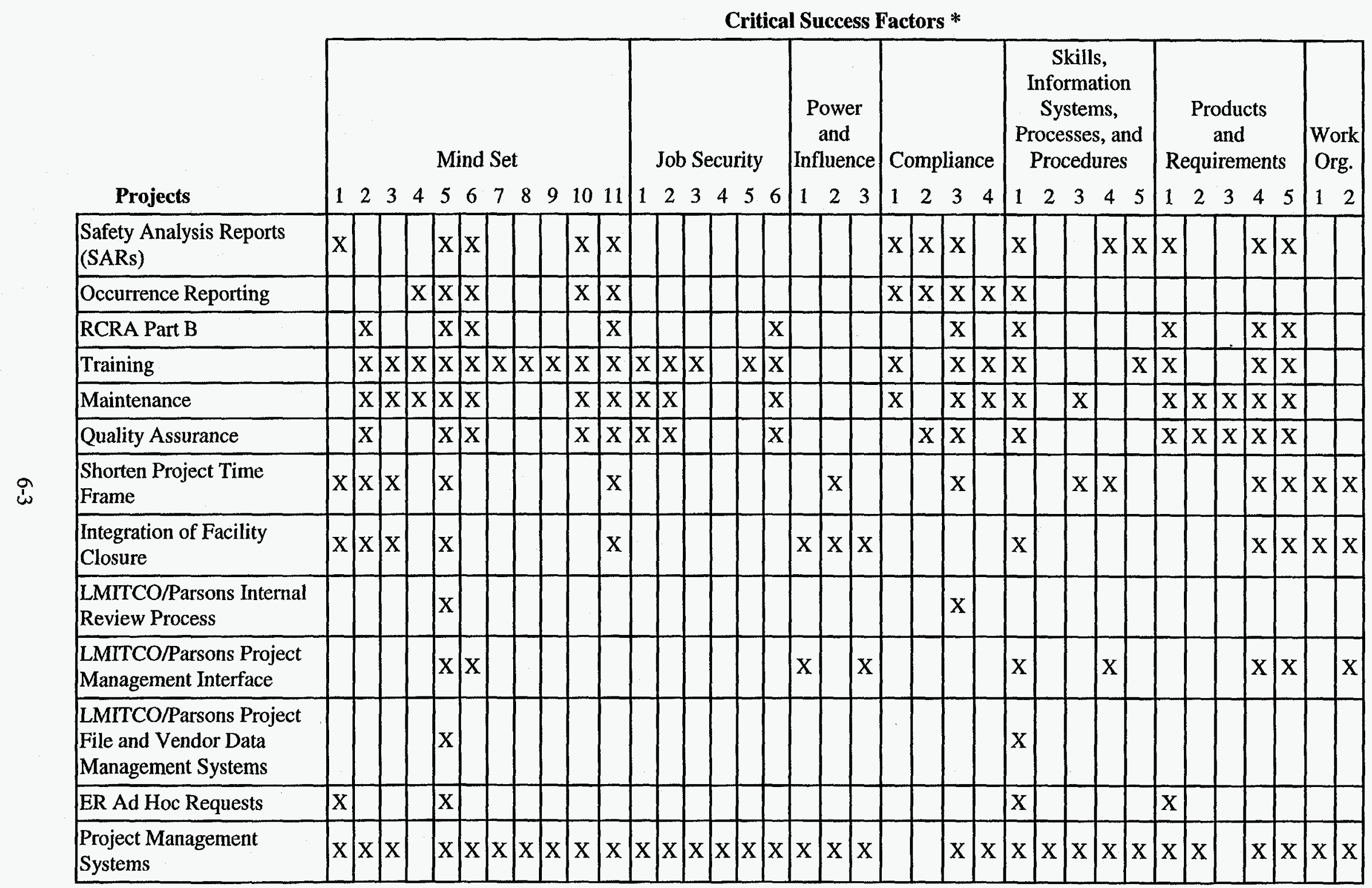

* numbers correspond to items listed in this section

Figure 6-1. Compliance reengineering projects critical success factors matrix. 


\section{REFERENCES}

J. C. Baker, R. J. Bargelt, L. M. Birkinbine, D. A. Groetzinger, M. P. Hodel, A. B. Hubbard, J. L. Tripp, Environmental Management Project Management Systems Reengineering Implementation Plan, INEL/INT-9700444, May 1997.

Code of Federal Regulations, Title 40, Protection of the Environment, Part 264, (40 CFR 264), "Standards for Owners and Operators of Hazardous Waste Treatment, Storage, and Disposal."

G. E. Ellis letter, GEE-27-97, Transmittal of Environmental Management Compliance Reengineering Phase One Report, January 31, 1997.

J. A. VanVliet, Environmental Management Compliance Reengineering Project Phase I Report, INEL/INT-97-00108, January 1997.

J. A. VanVliet letter, JVV-33-97, Transmittal of Environmental Management Compliance Reengineering Phase II Report, May 30, 1997.

J. A. VanVliet, Environmental Management Compliance Reengineering Project Phase II Report, INEL/INT-97-00268, May 1997. 


\section{Appendix A}

\section{Compliance Reengineering Document: Phase I}




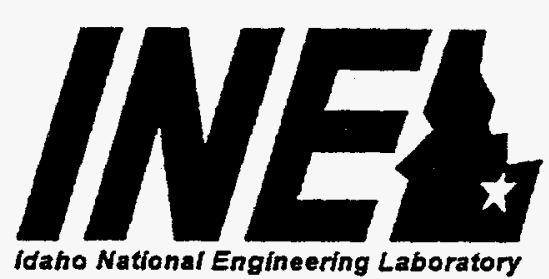

idaho National Engineering Laboratory
LOCKHEED

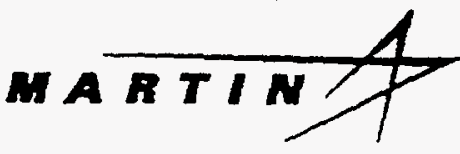

Lockheed Martin Idaho Technologies Company

P. O. Box 1625

Idaho Falls, ID 83415-3940

Telephone: (208) 526-8632

Facsimile: (208) 526-8632

Mailstop 3940

December 23, 1996

Mr. J. L. Lyle, Assistant Manager

Office of Program Execution

U.S. Department of Energy

Idaho Operations Office

850 Energy Drive, MS 1203

Idaho Falls, ID 83401-1563

\section{COMPLETION OF ENVIRONMENTAL MANAGEMENT COMPLIANCE REENGINEERING IMPROVEMENT PLAN, PHASE ONE - GEE-89-96}

Dear Mr. Lyle:

We have selected the initial projects to be included in the INEL Environmental Management (EM) Compliance Reengineering Improvement Plan. Following a disciplined analysis process, twenty improvement opportunities, organized into five major improvement projects were selected for final design and implementation in Fiscal Year (FY) 1997. This represents the completion of Phase 1 of the FY 1997 Compliance Reengineering Task.

This selection was made by a combined Lockheed Martin Idaho Technologies Company (LMITCO) and Department of Energy, Idaho (DOE-ID) Steering Board on Thursday, December 19, 1996, on the recommendation of a combined LMITCO and DOE-ID Compliance Reengineering Team. I appreciate the valuable contributions made by DOE-ID personnel, as members of the Compliance Reengineering Team and as Steering Board Members in this process. We have once again demonstrated our ability to work as one team in solving NEL challenges.

The process used for Phase 1 involved several hundred personnel from EM and support organizations within LMITCO and DOE-ID in evaluating how compliance related work is now accomplished at the INEL and in making specific recommendations for improvements. LMITCO and DOE-ID partnered with a private sector company, Gerald Dunn Inc. (GDI) for Phase 1, to obtain expert consultation on reengineering processes and tools. Of special note was the focus of the process on defining conflicting cultural and organizational obstacles.

Frequent Compliance Reengineering Steering Board Meetings provided direction as the Team designed potential projects on the basis of hundreds of comments and recommendations received in a very interactive process from INEL personnel. 
Mr. J. L. Lyle

December 23, 1996

GEE-89-96

Page 2

The twenty opportunities, as organized into the five major projects, with opportunity numbers corresponding to the Project Element indicated on the attached INEL Project Sort Analysis, are:

Areas of Opportunity for Improvement

I. Safety

1. Operational Requirements Manual Elimination - NWCF/CPP

2. SAR Reports (SARs)

3. Occurrence Reporting

II. Environmental

8. Environmental Restoration - Streamlining Document Review

10. Permitting - RCRA Part B- eliminate unnecessary detail

Environmental

III. Operations

11.a. Training - Trainee Time

11.b. Training - Training Staffing Levels

12. Maintenance

13. Quality

15. Engineering Support

16. Work Processes

IV. Project Management

18. Shorten Project Time Frame

Safety

1998

Benefits

$\$ \mathrm{~K}$

2,500

4,200

262

6,962

976

1,350

2,326

1,600

1,400

2,800

2,400

3,300

1,500

Operations
1998-2002

Benefits

\$K

10,860

16,904

1,048

28,812

19.a. Consolidate Roles \& Responsibilities - Construction Pjc't Mgm't

8,700

19.b. Consolidate Roles \& Responsibilities - Cost Estimating

200

6,500

5,700

11,200

9,800

13,200

5,000

51,400

19.c. Consolidate Roles \& Responsibilities - Facility Closedown, Deactivation \& Demolition

20. LMITCO/Parsons - eliminate organizational redundancies

21. Subcontractor Project Management Systems

V. Budgeting \& Performance Measures

22. Budgeting

3,000

11,400

8,000

2,000

24,950

23. Data and Information

5,000

8,000

12,000

24. Performance Measures

4,500

12,000

32,000

Budgeting \& Performance Measures

12,500

145,862 
Mr. J. L. Lyle

December 23, 1996

GEE-89-96

Page 3

Please treat these as preliminary estimates. As we continue to develop and execute the implementation plans for these projects, it is anticipated that these projected savings may change and some projects may be added or dropped. We have, however, identified sufficient opportunities to meet the Compliance Reengineering cost savings target for FY 98 through 2002.

A report detailing the projects as well as explaining the disciplined process which lead to our decisions will be forwarded to DOE-ID in January 1997.

Please address specific questions relative to this task to J. A. Van Vliet, LMITCO Compliance Reengineering Board Chairman, or J. N. Davis, LMITCO Project Manager.

Sincerely,

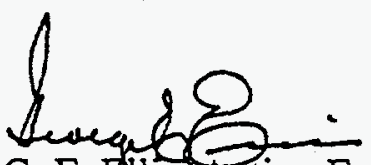

G. E. Ellis, Acting Executive Vice President Operations

$\mathrm{dkm}$

Attachment:

NNEL Projects Sort Analysis

cc: DOE-ID

M. R. Arenaz, MS 1150

G. L. Beausoleil, MS 4201

J. L. Burns, MS 1244

J. T. Case, MS 1118

R. C. Cullison, MS 1146

P. J. Dirkmaat, MS 1154

B. G. Edgerton, MS 5121

L. L. Fritz, MS 1118

J. W. Hobbs, MS 4160

N. R. Jensen, MS 4160

W. D. Jensen, MS 5121

W. H. Leake Jr., MS 1117

W. G. Lloyd, MS 1244

R. A. Taft, MS 4160

R. M. Stallman, MS 1101

M. V. Willcox, MS 1146

A. C. Williams, MS 1103
LMITCO

W. A. Baxter, MS 3670

L. M. Coggins, MS 3133

W. J. Denson, MS 2437

K. M. O'Donnell, MS 3406

K. L. Falconer, MS 3921

F. L. Grant, MS 2437

J. E. Hovinga, MS 5233

J. F. Jaggers, MS 3750

A. M. Jensen, MS 3204

T. H. Judd, MS 3670

T. A. Mathews, MS 5229

S. A. Scobby, MS 3580

R. N. Snelling, MS 2213

C. L. Tellez, MS 3428

J. A. VanVliet, MS 3406

M. J. Wolters, MS 3940

P. S. Yela, MS 5108

GDI

A. G. Dunn 


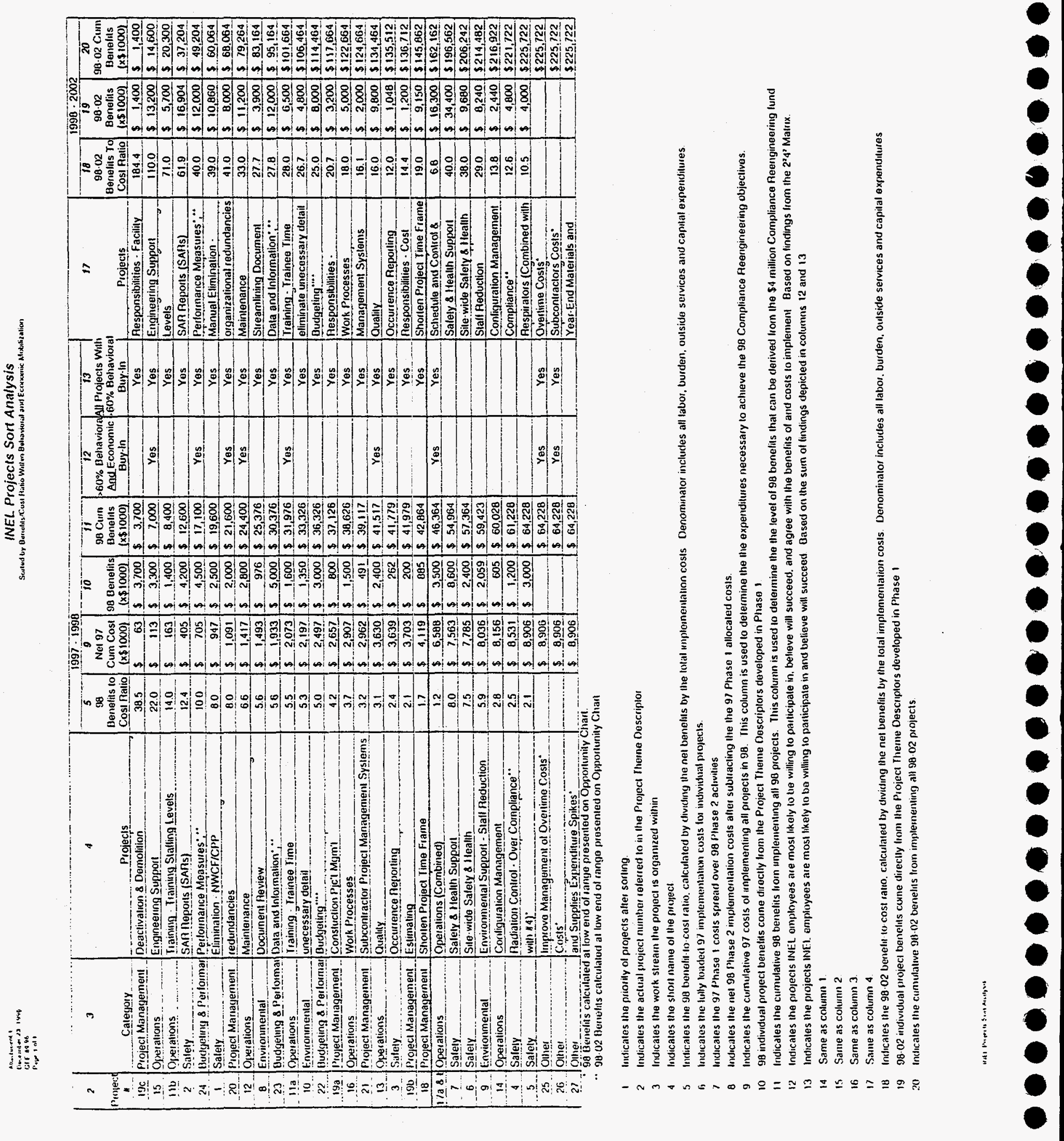




\section{Appendix B \\ FY 1997 Projects \\ Benefits of Compliance Reengineering}


Table B1. FY 1997 projects benefits (in \$M) of compliance reengineering - phase I, II, and III comparison.

\begin{tabular}{|c|c|c|c|c|c|c|c|}
\hline \multirow[b]{2}{*}{ Stream/Project $*$} & \multicolumn{2}{|c|}{ Phase I Estimate } & \multirow{2}{*}{\multicolumn{2}{|c|}{$\frac{\text { Phase II Estimate }}{\text { FY-98 FY-98-02 }}$}} & \multicolumn{2}{|c|}{ Phase III Estimate } & \multirow[b]{2}{*}{ Comments/Section } \\
\hline & FY-98 & FY-98-02 & & & FY-98 & FY-98-02 & \\
\hline \multicolumn{8}{|l|}{ I. Safety } \\
\hline 1. Operational Requirements Manual & 2.5 & 10.86 & & & & & Combined with \# 2 (section 4.1) \\
\hline 2. Safety Analysis Reports (SARs) & 4.2 & 16.904 & 3.15 & 5.3 & 9.687 & 17.49 & (section 4.1) \\
\hline 3. Occurrence Reporting & .262 & 1.048 & .14 & 1.0 & .262 & 1.0 & (section 4.2) \\
\hline $\begin{array}{l}\text { 6. Safety \& Health - Site-wide Ad } \\
\text { Hoc Requests }\end{array}$ & & & .15 & .8 & .15 & .8 & $\begin{array}{l}\text { Changed to Environmental Restoration } \\
\text { Ad Hoc Requests, Stream IV (section } \\
\text { 4.11) }\end{array}$ \\
\hline \multicolumn{8}{|l|}{ II. Environmental } \\
\hline $\begin{array}{l}\text { 8. Environmental Restoration - } \\
\text { Streamline Document Review }\end{array}$ & .976 & 3.9 & .3 & 1.475 & .3 & 1.475 & $\begin{array}{l}\text { Renamed LMITCO/Parsons Internal } \\
\text { Document Review Process, Stream IV } \\
\text { (section 4.8) }\end{array}$ \\
\hline 10. RCRA Part B permit & 1.35 & 4.8 & .615 & 3.04 & .483 & 2.485 & (section 4.3) \\
\hline \multicolumn{8}{|l|}{ III. Operations } \\
\hline 11a. Training - Trainee Time & 1.6 & 6.5 & 133 & 6645 & 133 & 6645 & Proiects combined (section 4 4) \\
\hline 11b. Training - Staffing Levels & 1.4 & 5.7 & $1.0 J$ & $0.0+3$ & 1.00 & $0.0+\pi$ & 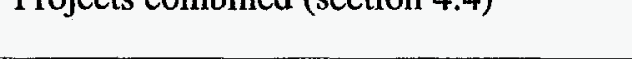 \\
\hline 12. Maintenance & 2.8 & 11.2 & 3.2 & 16.0 & 1.403 & 9.257 & (section 4.5) \\
\hline 13. Quality & 2.4 & 9.8 & .5 & 4.5 & & & Deferred to FY 1998 in Phase III \\
\hline 15. Engineering Support & 3.3 & 13.2 & & & & & Deferred to FY 1998 \\
\hline 16. Work Processes & 1.5 & 5.0 & & & & & Combined with \#12 (section 4.5) \\
\hline IV. Project Management & & & & & & & $\begin{array}{l}\text { Renamed Facility Construction and } \\
\text { Closure }\end{array}$ \\
\hline 18. Shorten Project Time Frame & .885 & 9.15 & 1.57 & 10.0 & .4 & 2.0 & (section 4.6) \\
\hline $\begin{array}{l}\text { 19a. Consolidate Roles \& } \\
\text { Responsibilities - Facility } \\
\text { Closedown, Deactivation, and } \\
\text { Demolition }\end{array}$ & 3.7 & 11.4 & .12 & 3.1 & .12 & 3.7 & $\begin{array}{l}\text { Renamed Integration of Facility Closure } \\
\text { (section 4.7) }\end{array}$ \\
\hline
\end{tabular}




\begin{tabular}{|c|c|c|c|c|c|c|c|}
\hline \multirow[b]{2}{*}{ Stream/Project * } & \multicolumn{2}{|c|}{ Phase I Estimate } & \multicolumn{2}{|c|}{ Phase II Estimate } & \multicolumn{2}{|c|}{ Phase III Estimate } & \multirow[b]{2}{*}{ Comments/Section } \\
\hline & FY-98 & FY-98-02 & FY-98 & FY-98-02 & FY -98 & FY.98-02 & \\
\hline $\begin{array}{l}\text { 19b. Consolidate Roles \& } \\
\text { Responsibilities - Const. Project } \\
\text { Management }\end{array}$ & .8 & 3.2 & & & & & Combined with \#18 (section 4.6) \\
\hline $\begin{array}{l}\text { 19c. Consolidate Roles \& } \\
\text { Responsibilities - Cost } \\
\text { Estimating }\end{array}$ & .2 & 1.2 & & & & & $\begin{array}{l}\text { Combined with Project Management } \\
\text { System, stream V (section 4.12) }\end{array}$ \\
\hline $\begin{array}{l}\text { 20. LMITCO/Parsons - Eliminate } \\
\text { Organizational Redundancies }\end{array}$ & 2.0 & 8.0 & 2.242 & 11.21 & 2.242 & 11.21 & $\begin{array}{l}\text { Renamed LMITCO/Parsons Project } \\
\text { Management Interface (section 4.9) }\end{array}$ \\
\hline $\begin{array}{l}\text { 21. Subcontractor Project } \\
\text { Management Systems }\end{array}$ & .491 & 2.0 & .183 & .914 & .183 & .914 & $\begin{array}{l}\text { Renamed LMITCO/Parsons Project File } \\
\text { and Vendor Data Management Systems } \\
\text { (section } 4.10 \text { ) }\end{array}$ \\
\hline $\begin{array}{l}\text { V. Budgeting and Performance } \\
\text { Measures }\end{array}$ & & & & & & & Renamed Business/Project Management \\
\hline 22. Budgeting & 3.0 & 8.0 & & & & & \\
\hline 23. Data and Information & 5.0 & 12.0 & 3.9 & 61.8 & 3.9 & 43.1 & $\begin{array}{l}\text { Projects combined and renamed Project } \\
\text { Management System (section 4.12) }\end{array}$ \\
\hline 24. Performance Measures & 4.5 & 12.0 & & & & & \\
\hline TOTAL & 40.364 & 145.002 & 17.4 & 125.784 & 20.46 & 100.076 & \\
\hline
\end{tabular}

* Numbers in column 1 correspond to phase I project numbers in Environmental Management Compliance Reengineering Project Phase I Report, INEL/NTT-97-00108. 